Historic, Archive Document

Do not assume content reflects current scientific knowledge, policies, or practices. 



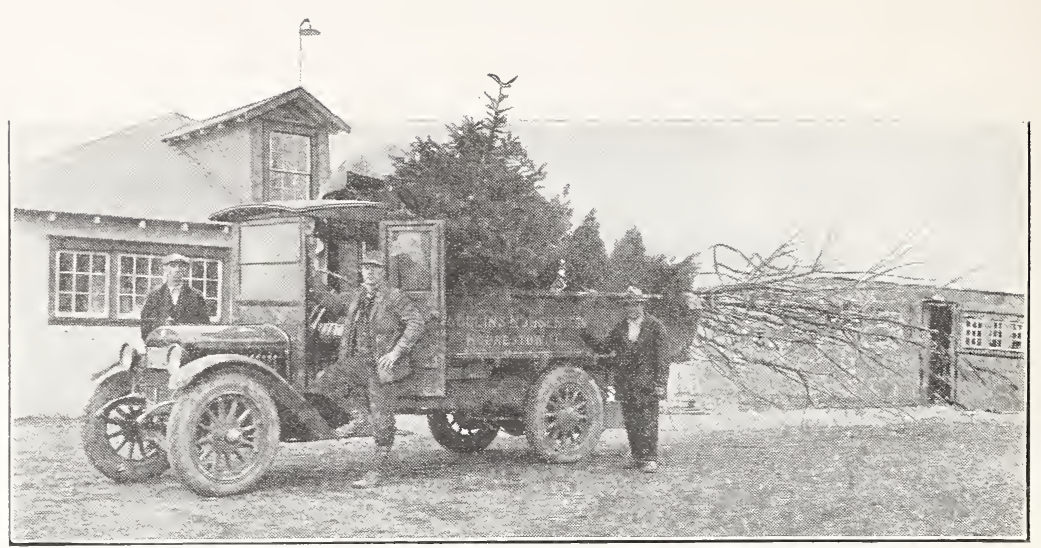

Increasing business requires adiditional packing houses, shown at right

\section{COLLINS 1926 Planting Guide}

\section{Greetings:}

In this new Planting Guide for 1926, we offer a more comprehensive list of flower, fruit, berry and ornamental plants than we have ever before offered in the history of our nursery-or in other words, since 1860. We can now furnish "The Best of Everything for the Home Grounds."

Last year was by far our "biggest year." We were very busy handling the largest volume of orders in our 65 years' experience. Yet our methods of propagating and growing, of filling orders and handling correspondence have more than kept pace with the steady increase year by year (which is most essential to any healthy Nursery business). All plans are made and much new equipment added for the easy handling of an even bigger increase in 1926.

Every step-from the systems of starting the small "plantlets" in the nursery rows, to the digging, packing and shipping of the matured plants-has been improved and speeded up. All to reach one goal, your satisfaction-to assure you greatest value and service, as well as downright pleasure, from all your dealings with us.

Look through this Guide. Fine plants are offered; each ready to yield according to its kind-the finest in roses, in flowers, in shrubs, in fruits, in berries. Plant them. Have results the first year, and for many pleasant years to follow.

To assure your success we send free with every shipment of plants, cultural instructions showing how to grow successfully the plants offered in this catalog. Although we realize that to many of our customers the most of this information is well known, we send it in all cases. It pays to err, if at all, on the side of being doubly sure. If you have any questions to ask us at any time, write us freely. We will gladly endeavor to aid you in solving your other problems regarding growing and care of plants.

We respectfully solicit your orders.
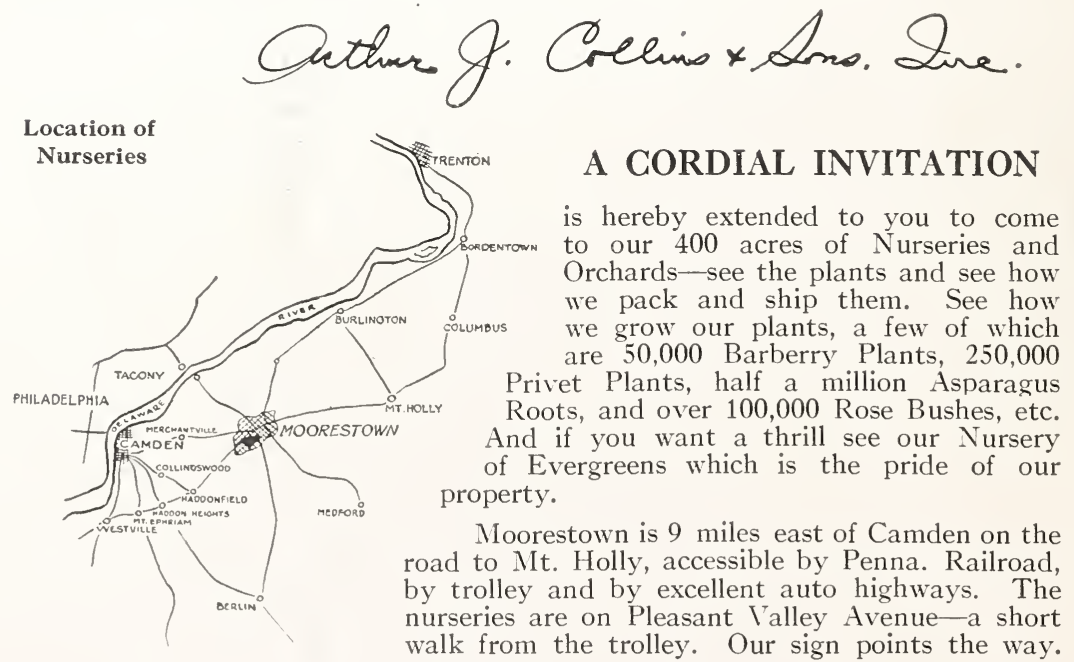


\section{COLLINS Faultless Five* ROSES}

Pick regular hot-house roses, of the finest varieties, from your own garden.

See the picture in natural colors, on the front cover. All five are monthly roses. Tremendous bloomers. A gorgeous display from Spring till frost.

1. COLUMBIA. The newest big pink rose.

("This single rose retails at local stores at the Collins' price of the whole five," writes one New York customer.)

2. GOLDEN OPHELIA. Big, brilliant flowers, similar in form to those of the famous original Ophelia, but with a gorgeous golden yellow suffusing its delicate salmon pink.

("This bush had seventeen buds and blooms on at one time; all my neighbors admired it," writes a customer in New Jersey.)

Front Cover 3. PREMIER. The most fragrant pink rose, big thornless stems.

4. DOUBLE WHITE KILLARNEY. Perfect buds of ivory white. Picture on front cover shows remarkable grace when opening.

5. AMERICAN LEGION. The choice, fragrant new red rose. Beautiful deep cerise flowers, on long stems.

Every plant has already bloomed. All guaranteed to grow and bloom for you, or your money back. Safe delivery guaranteed.

\section{Big, Thrifty Rose Bushes \\ Strong-rooted, 2- or 3-year old

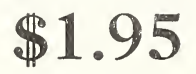

Cut back to about 2 feet high. All ready for planting.

All five, Postpaid. (If west of Mississippi River, add 10c).

\section{Collections \\ 30 Bushes \\ Postpaid $\$ 9.75$}

Mailed to same address, or to six different addresses-all for $\$ 9.75$ Postpaid. (If west of Mississippi River, add 60c).

You pay for five collections-get one collection FREE.

Note that one of these $\$ 1.95$ Rose collections is sent absolutely free to any customer ordering five (5) additional collections all at one time. This rose collection makes a fine gift to a distant friend, or you can sell them among your neighbors-having the six collections all delivered to you- or direct to the various addresses, without any addition to our $\$ 9.75$ charge.

Hundreds of our customers have written very gratifying letters to us telling of the splendid blooms they have cut from their bushes last year, from a few weeks after planting until a killing frost. These roses bloom right through the dry, hot summer months, and abundantly in the fall. If your garden space is limited, plant Roses for a wealth of superb bloom.

Purchasers of this Collection have returned to our office exclaiming that our color picture of these five blooms is no exaggeration, the roses produced the first year actually looked superior to color photograph shown on front cover.

*The name "Faultless Five" was suggested by a well satisfied customer of the 1923 season, who lives in the far west. She has continued to order from us every season since-as do thousands of other customers the country over.

It's only natural. Where else could she-OR YOU-secure at so moderate a price, roses of such fine varieties; such thrifty plants; and so remarkable a protection as

\section{OUR GUARANTEE}

that these roses will grow and bloom for you this year, or your money back. With every collection goes a blank which shows how we protect you absolutely on this point. Easy

This package carries roses whesully any- cultural directions with every collection.

here. Orders filly an otation.

\section{GOLLINS NURSER IES}

ARTHUR J. COLLINS \& SONS, INC. BYRON C. COLLINS AR'T

MOORESTOWN, NEW JERSEY

Parcel Post, express or freight delivery for long distances
Established 1860

For index see page 67
Our rapid truck delivery for nearby noints 


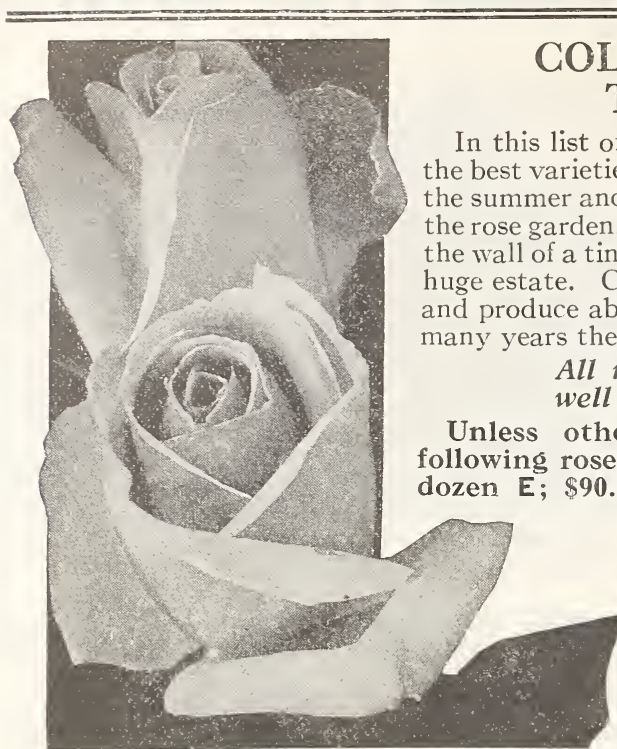

Betty

COLLINS HYBRID TEA ROSES

In this list of Hybrid Tea Roses you will find the best varieties of roses that will bloom through the summer and fall and that are best adapted to garden, whether they are planted next to of a tiny home or in the large garden of a Collins roses are grown full of life, and produce abundantly the first season and for All roses two years old,
well established in pots.

Unless otherwise noted, prices of all following roses are $\$ 1.10$ each $E ; ~ \$ 12.00$ per dozen $E ; \$ 90.00$ per hundred $E$.

\section{"They Bloom All Summer and Fall",}

AMALIE de GREIFF. This is a fine bedding rose, producing long, well-shaped buds of delicate rose-tinted white on long, stiff stems. Very popular.

ANTOINE RIVOIRE. This is quite a vigorous blooming bush, producing delicately formed roses of rosy-flesh color on a yellow background, delicately edged with carmine. Base of petals yellow.

*BETTY. When once established in your garden, this bush produces deliciously scented flowers of coppery-rose color, suffused with a tint of yellow. One of the best bloomers in Autumn.

*CAROLINE TESTOUT. A beautiful rose with large full flowers of clear rich pink, delicately edged with silvery rose. Very fragrant. Produces blooms very freely.

COLUMBIA. (See color illustration, front cover.) A splendid full double rose of very lasting qualities. A strong grower, almost thornless, with brilliant rose-pink flowers. Delightfully fragrant.

CONSTANCE. A very free

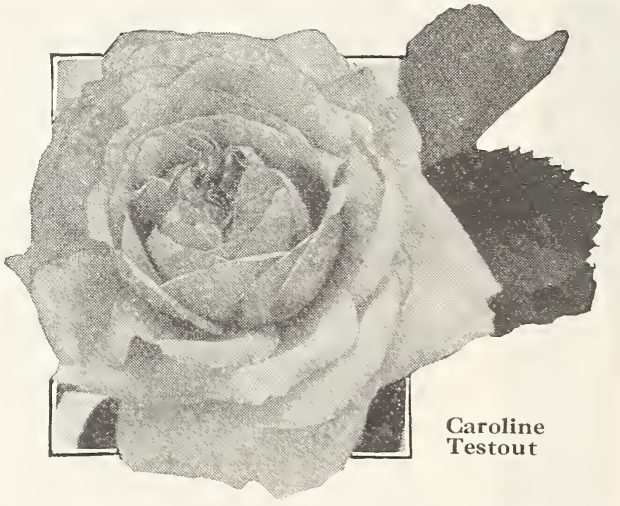
flowering variety, which produces exquisite orange-yellow buds, long and of perfect form. Golden yellow blooms, $\$ 1.50$ each $\mathbf{E}$.

DUCHESS OF WELLINGTON. Delightfully fragrant, free flowering rose, with large, thick petals, making them last longer when cut. The flowers are intense saffron and yellow, opening to deep copper-saffron yellow flowers. A charming variety.

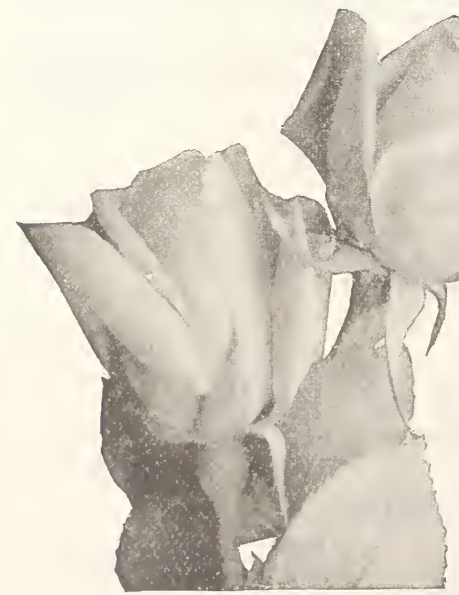

Constance

EDEL. Quite recent, best white ever introduced. Deep enormous blooms, strong, well-formed, hardy. Pure white, ivory touch at base of petals. Delightfully sweet scented. Free flowering, sturdy grower.

EDGAR M. BURNETT. Large, flesh colored petals, tinted rose and exquisitely sweet scented. The flowers are all well formed, very large and full.

FELICITY. This is a beautiful shade of mallow-pink, shading to cerise at the edges with a soft creamy shading at the base of the petals. Excellent in buds, developing into splendid cupshape sweet-scented. Vigorous growth. Remarkably free flowering habit. Each $\$ 1.50 \mathrm{E}$.

FLORENCE PEMBERTON. This is a very free flowering rose, creamy white, suffused with clear pink and a well-formed flower with a high, pointed center and deep petal. Fine bedding rose. 
*GENERAL MAGARTHUR. Intensely glowing crimson scarlet, highly scented and a very prolific bloomer. One of the best of bedding roses. Well known.

GORGEOUS. Amber-yellow with red-coppery veins. Striking and novel. The bush is vigorous and strong.

GRANGE COLOMB. This is a strong, vigorous growing bush and a splendid bedding rose. Ivory white with salmon-yellow center. As the flowers open they change to a pure white.

*GRUSS AN TEPLITZ. Rich, scarlet flowers, blending velvety crimson, set off by beautiful green foliage. Long, stiff stems, making it valuable for cutting. Very fragrant. A strong grower and in bloom all the time.

HADLEY. One of the very finest bedding roses, with

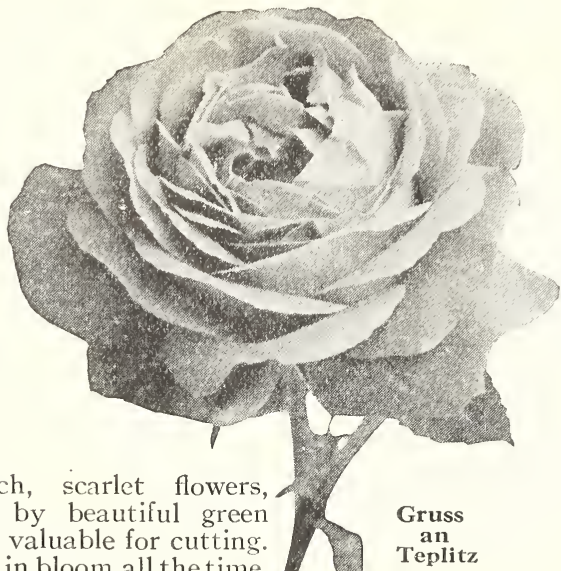
its rich, velvety crimson flowers, intensely fragrant and producing very freely. Blooms continue throughout the season. Each $\$ 1.25 \mathrm{E}$.

HOOSIER BEAUTY. This is a valuable rose for cutting as the flowers are firm and last a long time. Its exquisite long buds are beautifully formed and its large, full flowers of intense dazzling crimson-scarlet are deliciously fragrant.

H. V. MACHIN. An intense dark, almost black, scarlet-crimson rose, of vigorous and sturdy habit. Borne on long stiff stems with beautiful foliage. An ideal cutting variety.

INDEPENDENGE DAY. This has an entirely new and distinctly novel coloring. A rich orange-apricot suffused with sunflower yellow. The buds are long and are delightfully fragrant and are produced very freely. Each $\$ 1.50 \mathbf{E}$.

IRISH FIREFLAME. A wonderful, single flowering variety. Produces in clusters of 5 or more and very popular for cutting in bud form. The buds are all rich deep orange and crimson and very rich, opening into large flowers of velvety old gold and yellow.

JONKHEER J. L. MOCK. These very large, perfectly formed blooms are highly scented and the blooms are produced in great profusion on strong, stiff stems. The flowers are deep, imperial Pink on the inside and rich carmine and silvery-rose white on the outside.

*KAISERIN AUGUSTA VICTORIA. A superb rose in every way. The handsome, long, pointed buds open up into blooms of the purest snow-white you have ever seen. Beautifully formed roses produced on long, graceful stems and the bush is a strong, free, healthy grower.

*KILLARNEY. This is the best known of the famous Irish Hybrid Tea Roses and is one of our most popular garden varieties. The buds are large, long and pointed with the petals deep and of great substance. Ideal for cutting and one that will produce you almost continuous bloom. A whole bed of these charming roses with their sparkling, brilliant pink blooms, is a gorgeous sight.

\section{PLEASE NOTE}

We shall see to it that all rose bushes are sent out at the proper time in the spring and if your bushes do not reach you quite as promptly as you expected after ordering, please remember that we have thousands of orders to fill and that we will not start to send them out until the weather is mild and, in our estimation, best suited for these valuable plants. You will greatly oblige us by not writing "hurry-up" letters. Leave the matter in our hands, we are experienced and will give you service.

For aids to rose growing, see page 64 .

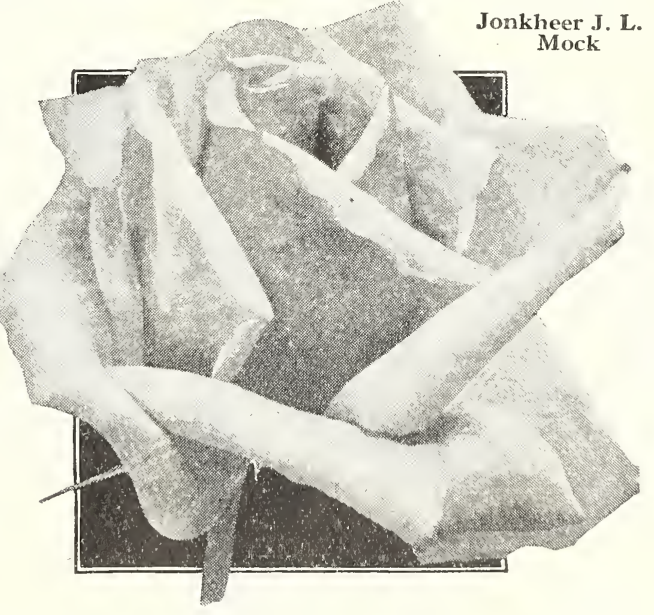

All above roses 2 yrs. old, well established in pots. Unlless otherwise noted, $\$ 1.10$ each $E ; \$ 12.00$ per dozen $E ; \$ 90.00$ per hundred $E$. 
Killarney

Brilliant
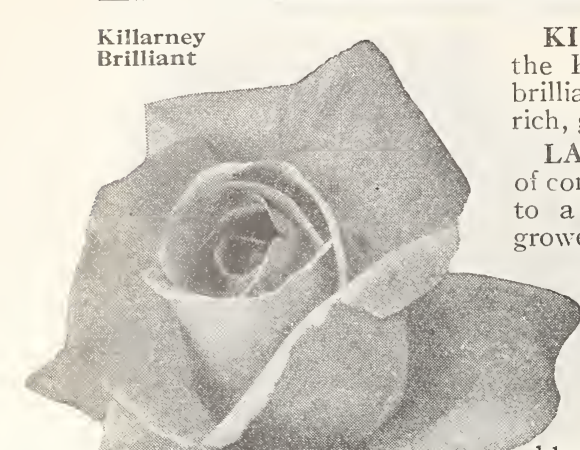

KILLARNEY BRILLIANT. Very similar to the Killarney, but of much brighter and more brilliant coloring and somewhat larger with a rich, glowing shade of carmine.

LADY ALICE STANLEY. A beautiful shade of coral rose with the inside of the petals shading to a flesh-pink. Very vigorous and healthy grower. Flowers immense and full.

LADY ASHTOWN. Exquisite pale rose, shading to yellow at the base of the petals. Large, full, well-pointed flowers, freely produced. Excellent for cutting, long-lasting qualities.

*LADY URSULA. A very vigorous and erect grower of exceedingly, free blooming habit, producing abundance of delicate, flesh-tinted flowers of high center and perfect form, distinct, and delicately teascented.

LAURENT CARLE. Brilliant, velvety carmine f.owers, produced in profusion throughout the season, deliciously sweet-scented. A vigorous grower, blooming right through the hot weather when most flowers are scarce.

*LOS ANGELES. This is one of the finest varieties ever produced. It is illuminous, flame-pink, toned with coral and shaded with translucent gold at the base of the petals. It is very vigorous and the buds are long and pointed, excellent for cutting, expanding into huge flowers of mammoth proportions. An entire bed of this wonderful rose is not too much to have.

*MME. EDOUARD HERRICT. The Daily Mail Rose. These buds of deep, coral-red shaded with yellow, open into flowers of medium size, senii-double of beautiful coral-red shaded with yellow and bright rosy-scarlet. (Awarded gold cup by London Daily Mail for best rose exhibited at International Horticultural Exhibition, May, 1912.) Exceedingly free bloomer.

MME.JULES BOUCHE. Nearly a pure white, slightly tinted with blush on the reverse of the petals, but considered one of the best white bedding roses, being quite double and exquisite in bud form, as well as when fully opened. A strong grower and a continuous bloomer.
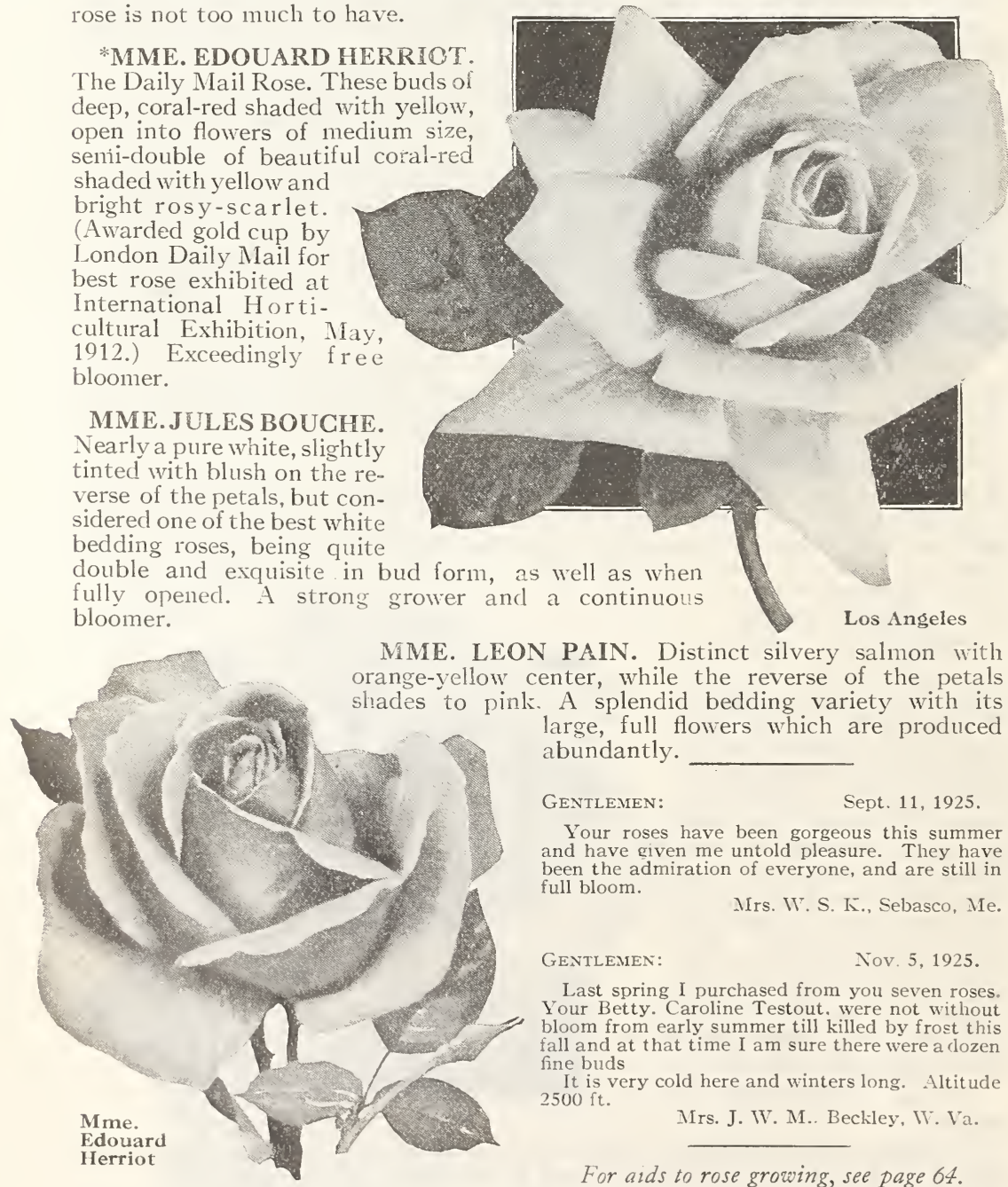

Los Angeles MME, LEON PAIN. Distinct silvery salmon with orange-yellow center, while the reverse of the petals shades to pink. A splendid bedding variety with its large, full flowers which are produced abundantly.

Gevtiemen:

Sept. 11, 1925.

Your roses have been gorgeous this summer and have given me untold pleasure. They have been the admiration of everyone, and are still in full bloom.

Mrs. W. S. K., Sebasco, Me.

GeNTLeMen:

Nov. 5, 1925.

Last spring I purchased from you seven roses. Your Betty. Caroline Testout, were not without bloom from early summer till killed by frost this fall and at that time I am sure there were a clozen fine buds

cold here and winters long. Altitude It)

Mrs. J. W. M.. Beckley, IV. Va.

For aids to rose growing, see page 64.

All above roses 2 yrs. old, well established in pots. Unless otherwise noted, $\$ 1.10$ each $E ; \$ 12.00$ per dozen $E ; \$ 90.00$ per hundred $E$.

E means by express (see page 67 ) 
MISS LOLITA ARMOUR. Quite recently introduced, but already very popular as a plant, is a strong, vigorous grower and produces abundant blooms throughout the summer. The flowers are quite double, large sized and of a very unique coloring, difficult to describe. As they expand they develop into a deep carmine-red with a gold, coppery-red suffusion. The base of the petals is a rich, golden yellow, with a coppery-red sheen. (Winner of the International Bagatelle Gold Medal Prize, Paris, 1921.) Each $\$ 1.50 \mathbf{E}$.

MRS. AARON WARD. Very abundant producer of charming, attractive full double roses of distinct Indian yellow centers, shading light toward the edges.

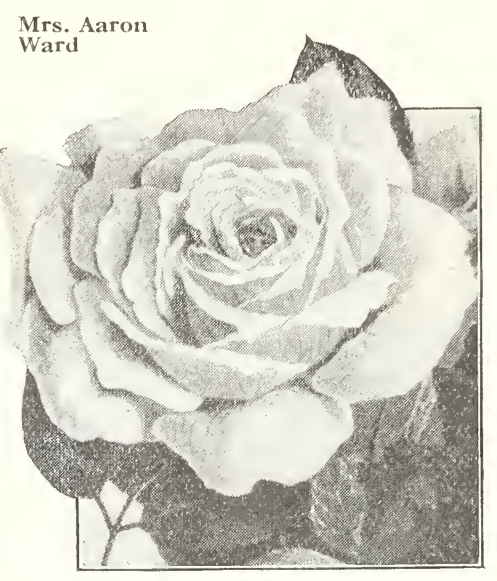
When first transplanted, the flowers are apt to be nearly white. The foliage is a rich, bronzy green and the bush is probably the most abundant producer of blooms of all the yellow Hybrid Tea Roses.

MRS. ARTHUR R. WADDELL. A very handsome free-flowering rose, especially alluring in the half-expanded form, with its soft rosy-salmon, suffused with a golden sheen, producing a distinct color. Very attractive and desirable.

MRS. CHARLES RUSSELL. This rose is very double and large, globular and well-formed. A pleasing, rosy-carmine with a scarlet center. Has fine foliage and flowers very freely. Very striking as cut flowers or in the garden.

MRS. FRANKLIN DENNISON. Becoming a very popular rose with its large full, well-formed flowers of shining white with a sheen of primrose yellow, which deepens to ochre at the base of the petals. Quite vigorous and blooms abundantly.

MRS. WAKEFIELD GHRISTHE-MILLER. This large sized flower lasts a long while on the bushes and is produced in abundance, a favorite among the pink bedding roses with its bright pink color shaded with lighter pink.

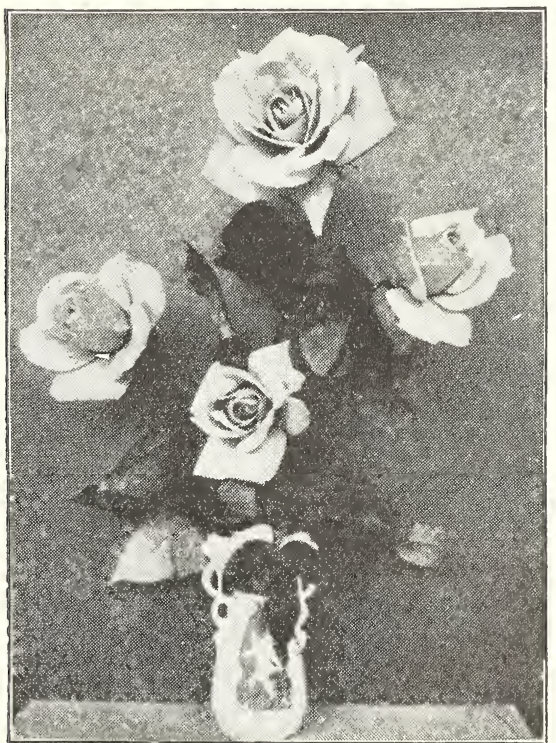

Ophelia-Compare Size with Vase

NEDERLAND. Very large deep red flowers, finely formed. These are borne on stiff stems; very free flowering. Quite recent introduction. Each $\$ 1.50 \mathrm{E}$.

*OPHELIA. A wonderful rose and ranking among the very best, admired by all who know it. Blooms appear from spring until frost on long, stiff stems, the flowers are of perfect form and of good size and of the most pleasing, delicate tint of salmon-flesh shaded with rose which makes the flowers peculiarly rich and enticing.

PADRE. New, strong grower and abundant producer of attractive flowers borne on long stems. The deep petals are of a coppery-scarlet, coloring flesh with yellow at the base. Very rich. $\$ 1.50$ each. E.

PHARISAER. This is a fine garden rose which blooms very freely, producing long, white buds that open into rosy-white flowers with just a touch of soft salmon, the blooms are large and quite double.

All above roses 2 yrs. old, well established in pots. Unless otherwise noted, $\$ 1.10$ each $E ; \$ 12.00$ per dozen $E ; \$ 90.00$ per hundred $E$.

$\mathbf{E}$ means by express (see page 67) 


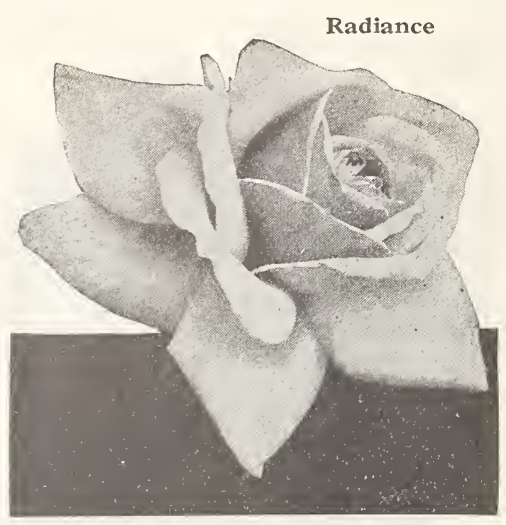

*RADIANCE. This is an ideal bedding rose bearing its flowers on long, strong stems, making it ideal for cutting. It blooms abundantly in June and continues to produce large flowers throughout the summer and fall, a brilliant, carmine-pink with salmon and lovely opaline tints, wonderful when expanded.

RED RADIANCE. An abundant producer as is Radiance and in color a clear cerise-red, very bright and not fading.

*ROSE MARIE. An exceedingly fine bedding rose, producing quantities of large, beautifully formed flowers, which are exquisite in bud form, long and pointed. A most pleasing, clear rosy-pink.

SOUVENIR DE CLAUDIUS PERNET. One of the best of the newer roses, in great demand, unusual beauty of form and coloring. Bright sunflower-yellow blooms, without any color blending, which hold their color better than any other yellow rose either in bud or open flower. Fine-formed buds long, firm and full are produced, and the stems are strong and upright, with brilliant green foliage. Awarded Gold Medals. \$2.00 each $\mathbf{E}$.

SOUVENIR DE GEORGES PERNET. Introduced two years ago, this strong vigorous grower produces large flowers which are beautiful in bud and fully developed forms. An intense oriental red shading to cochineal carmine at the margin of the petals. All suffused with a golden sheen. Very brilliant in its coloring. $\$ 1.50$ each. E.

All above roses 2 yrs. old, well established in pots. Price, except where noted, $\$ 1.10$ each $E ; \$ 12.00$ per dozen $E ; \$ 90.00$ per hundred $E$.

\section{Special Offer Collins Rose-Garden Dozen Collection}

We offer you the above twelve Everblooming Roses marked with a star thus (*), as a model rose-garden collection. This comprises the varieties best adapted to varying climatic conditions and those best suited to the amateur as well as the professional rose lover and grower. We offer you this model collection in the 2 year size, $\$ 12.00$, extra strong potted plants.

\section{Collins Hybrid Perpetual Roses Best Hardy Favorites}

GENERAL JAGQUEMINOT. (General Jack). These brilliant, scarlet crimson flowers are borne in profusion and succeed everywhere. An old favorite for many years, tried and true.

FRAU KARL DRUSCHKI, or White American Beauty. Undoubtedly the best white rose in existence, superb in every way, pure white in color, perfect in form, the perfect double flowers measuring 4 to 5 inches across. The long pointed buds are immense. Very abundant bloomer and hardy wherever roses grow.

PAUL NEYRON. Beautiful, clear pink, huge flowers measuring 5 to 6 inches across. Magnificent.

MAGNA CHARTA. A beautiful, bright pink, suffused with carmine. A bright, strong and vigorous grower, among the best.

Collins offer these sturdy, hardy rose bushes, which are hardy anywhere in the U. S., extra strong, potted plants 2 years old $\$ 3.90 \mathrm{E}$ for the above four; $\$ 1.00$ each $E ; \$ 12.00$ per dozen $E ; \$ 90.00$ per hundred $E$.

\section{ROSA HUGONIS. A RARE NEW ROSE}

This is a fine new species of rose, introduced from China and is of shrublike habits of growth and form, very symmetrical, size about 6 feet high and wide. Fine for cemetery plantings, for hedges and any shrubbery plantings. It has been known to bloom during a snow-storm and the entire plant is covered with bright, sunshiny yellow blooms and buds, making a wonderful early spring display. The color is intense canary-yellow, very bright and attractive. In the fall red scarlet berries are formed which remain on all winter. Perfectly hardy. $\$ 1.50$ each $\mathbf{E} ; \$ 15.00$ per dozen $\mathbf{E}$. 


\section{Collins Best Glimbing Roses}

COLLINS GLIMBING AMERIGAN BEAUTY ROSE. A cross between American Beauty and an unnamed seedling. Color rosy crimson, almost identical with the American Beauty. It has an exquisite fragrance, a quality rarely found in climbing roses. Collins Climbing American Beauty has a strong habit of growth. Will thrive and bloom in almost any situation where a climbing rose is desired. Flowers 3 to 4 inches in diameter, finely formed on long stems, are produced in great profusion. Comes into flower the latter part of May and continues in full flower for weeks.

SILVER MOON. This is the grand. est, white climbing rose, different from all other roses with its beautiful semi-couble flowers $4 \frac{1}{2}$ inches or more in diameter, petals are of great substance and beautifully formed, expanding attractively.

PAUL'S SCARLET CLIMBER. This is a fine, new climbing rose of vivid scarlet shade with bright crimson flowers. The brightest, red, hardy climbing rose in existence and no doubt the most bril-

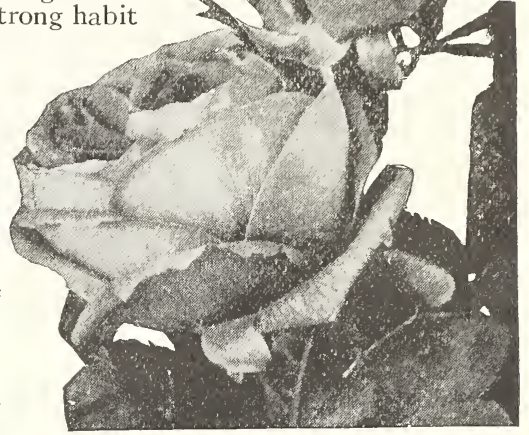

Climbing American Beauty liant addition to roses in many years. They are produced freely in clusters of from 3 to 20 flowers each on large branched canes and the bushes are clothed with vivid coloring from top to bottom.

GARDENIA. The flowers, borne very profusely in June and July, are deep, rich, golden-yellow in bud form opening into double flowers of cream which fold up at evening. The bush is a strong, hardy grower as tough as an oak. Flowers are large and fine for cutting. Among the best of all of the climbing yellow kinds.

SPEGIAL OFFER: One each of the above, making four roses in all, for $\$ 3.90 \mathrm{P}$; each $\$ 1.00 \mathrm{P}$; per doz., $\$ 11.00 \mathrm{P}$; per hundred $\$ 90.00 \mathrm{E}$.

AMERICAN PILLAR. Grand new climbing rose. Tremendous grower with vigorous canes and glossy dark green leaves. Flowers rosy pink to brilliant carmine with beautiful golden yellow stamens, blossoms arranged in layers four to six deep. Often 3,000 flowers on a young bush!

DR. W. VAN FLEET. The flesh-pink Climbing Rose. Open flowers are 4 inches and over in diameter, with high built center and beautifully undulated and cupped petals. Delicate outer surface deepening to rosy flesh in the center. Full and double, delicately perfumed, buds pointed, stems 12 to 18 inches long.

\section{THOUSAND BEAUTIES.}

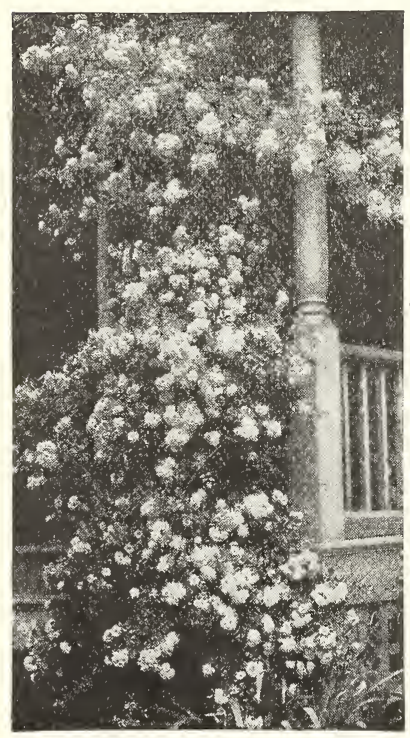

Dr. W. Van Fleet

P means by Parcel Post, Postpaid E means by express (see page 67)
Imagine a luxuriant climbing rose literally covered with thousands of bright blossoms, borne in clusters and quite double. Colors of every imaginable shade from white to deep pink. A vigorous grower with few thorns and handsome foliage.

Prices for above three roses, each $\$ 1.00 \mathrm{P}$; per doz., \$11.00 P.

\section{Two New Climbing Roses}

MARY WALLACE. An excellent new pillar Rose, strong-growing, self-supporting. Grows 6 to $8 \mathrm{ft}$. high. Fine glossy foliage. Spring blooms in profusion. Blooms till fall. Large, well-formed flowers, mostly more than 4 inches across, semi-double of a bright clear rose-pink with salmon at base of petals. Each $\$ 1.50 \mathrm{P}$.

AVIATEUR BLERIOT. Fine stronggrowing Rose with beautiful, pointed buds and semi-double flowers of saffron-yellow on long stems. Each $\$ 1.50$ E.

\section{Collins Rambler Roses}

Pink Dorothy Perkins. Clear, shell-pink petals, crinkled.

White Dorothy Perkins. Pure white. Very free-flowering.

Red Dorothy Perkins. Clear carmine-lake, profuse to bloom.

SPECIAL OFFER: One each of the above, 3 roses in all, 2-yr. size, $\$ 2.00 \mathrm{P}$; or each 75 cts. $P$.

Quantity prices on application. 
COLLINS NURSERIES, MOORESTOWN, N. J.

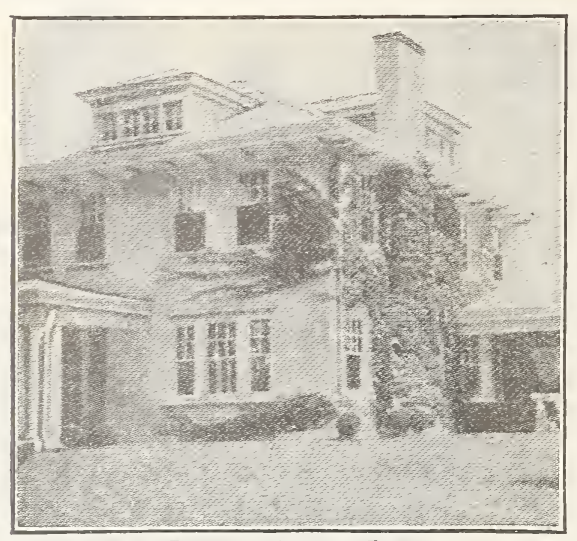

\section{VINES AND CLIMBERS}

CLEMATIS (Fackmani). Beautiful large-flowering Clematis, very popular on account of its rich purple flowers. The plants like moist, rich, fertile soil (not sour); set the crowns three inches below the surface. Each 90 cts. P; per dozen $\$ 9.00 \mathrm{P}$; strong vines.

CL E M A T IS (Paniculata). Flowers small, rich creamy white, borne in handsome clusters, completely covering the vine; exceedingly fragrant. The sweetest of all Clematis and one of the hardiest and easiest to grow. Good, strong 2 -yr. plants, 50 cts. each, 4 for

$\$ 1.50$; extra-size, 3 -yr. plants, 75 cts. each, 4 for $\$ 2.50$, all postpaid.

DUTCHMAN'S PIPE. Curious flowers, shaped like pipes. This is a fast growing vine, having large foliage making dense shade. 2 yr. 85 cts. each $\mathbf{P} ; \$ 8.50$ per dozen $P$.

\section{HONEYSUCKLES}

Everblooming Honeysuckle (Heckrottii). Color is crimson-carmine on the outside of the flower, which contrasts beautifully with the golden apricot of the inside as the flower opens. Blooms unceasingly all season.

Red Coral Honeysuckle. A hardy, rapid grower, suitable for rockwork, walls, etc. Flowers coral-red, very pretty.

Prices of above 2 Honeysuckles, 2-yr., each 75 cts. P; per dozen

$\$ 7.50 \mathrm{P} ; 3$-yr., each $\$ 1.00 \mathrm{P}$; per dozen $\$ 10.00 \mathrm{P}$.

The Beautiful Halliana Honeysuckle. This variety is intensely sweet-scented. It is a strong, clean, neat grower, perfectly hardy, almost evergreen, with leaves that shine as if varnished; constant and most profuse bloomer; flowers buff-yellow, passing to white. 2-yr., $50 \mathrm{cts}$. each, $\$ 5.00$ per doz.; 3-yr., 75 cts. each, $\$ 7.50$ per doz., all postpaid.

\section{IVY}

Japan, or Boston (Ampelopsis Veitchii). For covering houses, churches, schools, etc., this vine has no equal. The handsome, deep green foliage changes in autumn to crimson. Extra strong, 2-yr. plants, $60 \mathrm{cts}$. each, $\$ 5.00$ per doz., postpaid. See photo at top of page.

American (A. quinquefolia). The true Virginia Creeper; hardy and noted for its brilliantly colored foliage in autumn. 2 -yr., $40 \mathrm{cts}$. each, $\$ 3.50$ per doz.; 3-yr., $60 \mathrm{cts}$. each, $\$ 5.00$ per doz., postpaid.

Hardy English (Heảera helix). A hardy, evergreen, climbing vine with dark, glossy green leaves. $65 \mathrm{cts}$. each, $\$ 6.50$ per doz., postpaid; large size, $85 \mathrm{cts}$. each, $\$ 8.50$ per doz., postpaid.

KUDZU VINE. One of the most rapid-growing vines in cultivation, growing to 50 or more feet in one season. The large foliage makes dense shade and bears small rosy-purple blossoms in summer. Just the thing where you want to cover an unsightly fence or drape an arbor in a very short time. 1-yr. 75 cts. each; 2 -yr. 90 cts. each, postpaid.

SILVER LACE VINE. A vigorous, strong plant, attaining a height of 25 feet or more and producing great foamy sprays of white flowers, rose-tinted, in spring and again in autumn. 2 yr. 85 cts. each $\mathbf{P} ; \$ 8.50$ per dozen $\mathbf{P}$.

\section{WISTARIAS}

Collins wistarias are valuable wherever tall-growing climbers are wanted. They are hardy, rapid growers, and the flowers are borne in long, pendulous clusters early in the season. Our plants are grafted (not seedlings) from specially selected stock, hence they are sure bloomers. For best results they should be planted in deep, rich earth, but they will thrive in sandy soils.

Chinese Blue. Lovely violet-purple flowers; deliciously sweet. 2-yr., each 75 cts. E; 3-yr., \$1.00 E. 2-yr. grafted vines, sure-to-bloom, \$1.00; 3 -yr., $\$ 1.25$, by express.

Chinese White. Very similar to the Blue Vistaria. The flowers are attractive, pure white, and very sweet scented. 2-yr., \$1.00; 3-yr., \$1.25, by express. Grafted vines, sure-to-bloom, 2-yr., \$1.25; 3-yr., \$1.50.

Vines received to-day in first class order and I must say you know well how to grow such, best I ever bought of two year old stock. Thanks for sending such good ones.-W. A. W., Chestnut $\mathrm{Hill}, \mathrm{Pa}$. 


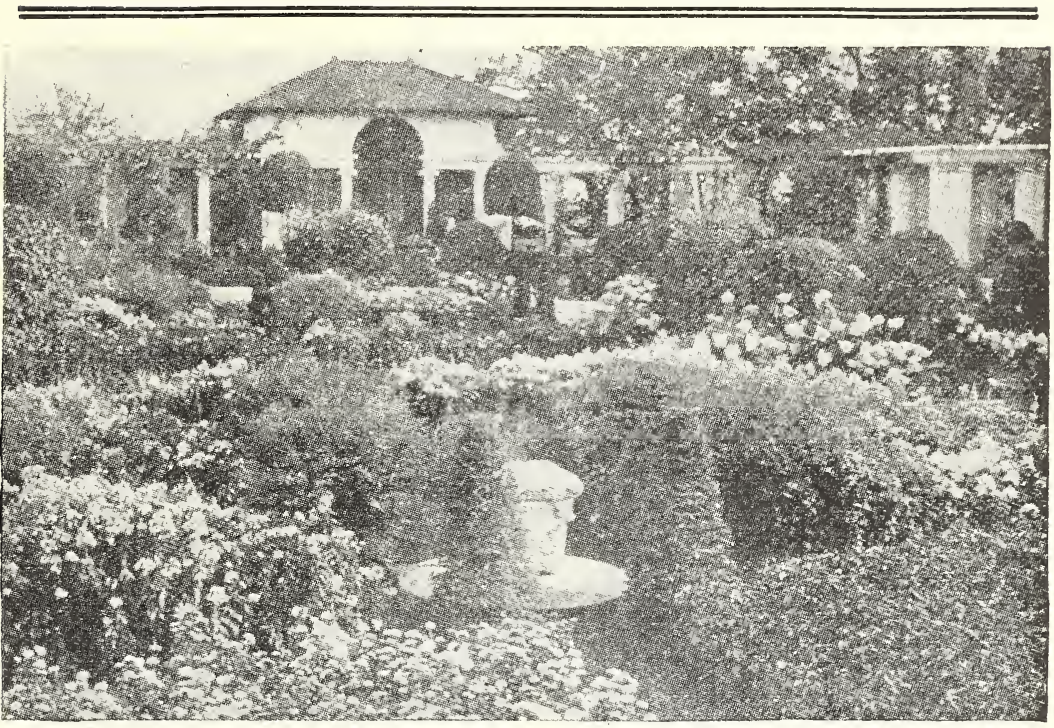

\section{Collins Favorite "Old Fashioned Flowers" HARDY PERENNIALS}

These hardyold-fashioned flowers enjoy even more renown today than in the days of our grandmothers, because of additions with more striking colors and forms.

Once planted these Perennials bloom gayly year after year, prospering with little or no attention and furnishing a never-ending source of cut-flowers and bouquets from earliest spring until even after frost.

Radiant in their bright color combinations, fascinating in form and detail, Hardy Perennials are desirable in all gardens, large or small.

We have greatly increased our Perennial plantings and can now offer the following in well-rooted, sturdy plants in biggest and most favorable sizes to give you the best results even the first year.

(In each description height and blooming periods are stated.)

\section{Achillea (Milfoil or Yarrow)}

Ptarmica, The Pearl. Indispensable in the border. Myriads of snow-white ball-shaped flowers, borne in great profusion. Excellent for cutting, makes it bloom more than ever. $2 \mathrm{ft}$. May to Oct. $30 \mathrm{cts}$. each $\mathbf{P} ; \$ 2.50$ per $10 \mathbf{P}$.

Anchusa Italica (Improved Italian Alkanet)

Dropmore Variety. Bright gentian-blue flowers in immense upright spikes comparable to Larkspurs in brilliance, and resembling giant forget-me-nots. Greatly improved. 3 to $6 \mathrm{ft}$. May to Aug. $35 \mathrm{cts}$. each P; $\$ 3.25$ per $10 \mathbf{P}$.

Anemone Japonica (Fapanese Windflower)

Queen Charlotte. Beautiful pale silvery pink flowers, a rare color among Perennials, semi-double, two or three inches in diameter. Very decorative foliage. Strikingly handsome plant in the border, among shrubbery or in clumps under trees. Excellent for cutting. 2 to $3 \mathrm{ft}$. Sept. and Oct. $30 \mathrm{cts}$. each $\mathbf{P} ; \$ 2.50$ per 10 P.

\section{Aquilegia (Columbine)}

These elegant forms and shadings with their beautifully divided foliage brighten the Border. Lavish blooms valuable for cutting.

Chrysantha. Tall, very beautiful. Bright yellow flowers with long spurs. $3 \mathrm{ft}$. May and June. $30 \mathrm{cts}$. each $\mathbf{P} ; \$ 2.50$ per $10 \mathbf{P}$.

Mrs. Scott Elliott's Strain. The best longspurred thrifty, hybrids. Large blooms of rich and varied colors, (pink, lavender, yellow, etc.), practically every one different. (Illustrated on page 10.) 2 to $3 \mathrm{ft}$. May and June. $30 \mathrm{cts}$ each $\boldsymbol{P}$. $\$ 2.50$ per $10 \mathbf{P}$.

Hardy Asters (Michaelmas Daisies)

Finest of all Hardy Asters, excellent for border plantings and shrubbery. Abundant wealth of bloom through September and October.

Perry's White. Very free-flowering. Large, graceful white flowers, excellent for cutting. $4 \mathrm{ft}$. 30 cts. each $\mathbf{P} ; \$ 2.50$ per $10 \mathbf{P}$.

Blue Gem. New, bright blue flowers with three or four rows of petals. The best blue Aster. $3 \mathrm{ft}$. $50 \mathrm{cts}$. each $\mathbf{P} ; \$ 4.50$ per 10 P.

P means by Parcel Post, Prepaid (West of Miss. R. add 10\%). E means by Express, see page 67. 


\section{Ghrysanthemum \\ (Collins "Tints of Gold")}

A glorious early-flowering Chrysanthemum, perfectly named, each flower embracing every possible shade and variation of gold from very deep rich yellow to burnished and "old gold," the tints marvellously blended. Flowers of aster form, excellent for cutting, blooming profusely. 35 cts. each $\mathbf{P} ; \$ 3$ per $10 \mathbf{P} ; \$ 20$ per $100 \mathbf{E}$.

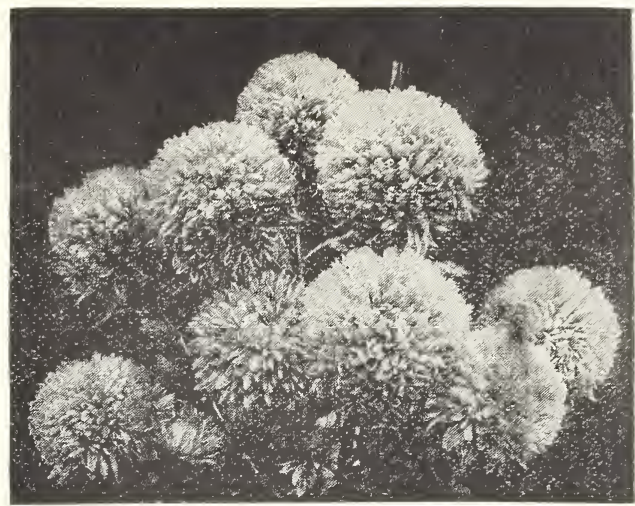

Chrysanthemums

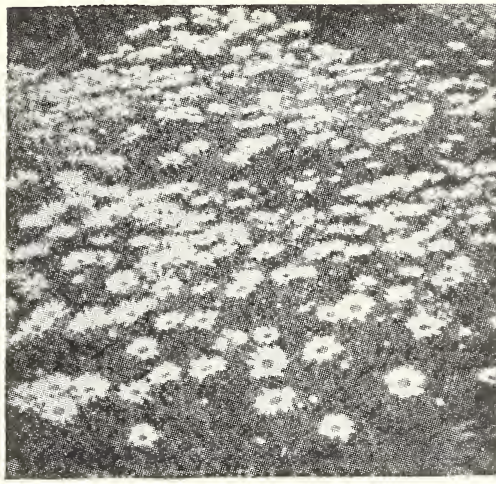

Shasta Daisy

\section{Chrysanthemum Maxi- mum (Shasta Daisy)}

A great favorite for cutting as the large, white daisy-like flowers, measuring over 4 inches across, are borne in great profusion over a long period. Developed by Burbank. $2 \mathrm{ft}$. June to Sept. $30 \mathrm{cts}$. each $\mathbf{P} ; \$ 2.50$ per $10 \mathbf{P}$.

\section{Centaurea (Hardheads or Knapwced)}

Macrocephala. Bright-yellow flowers, globular and thistle-like, often 3 or 4 inches in diameter. Handsome foliage. Excellent for borders and cut-flowers, keeping fresh a long time. 4 to $5 \mathrm{ft}$. July ind Aug. $30 \mathrm{cts}$. each P; $\$ 2.50$ per $10 \mathbf{P}$.

Montana. Large blue flowers, turning purple with age. Compact dwarf plants, fine for edging. $11 / 2 \mathrm{ft}$. June to Sept. 30 cts. each $\mathbf{P}$; $\$ 2.50$ per $10 \mathbf{P}$.

\section{Delphinium (Hardy Larkspur)}

Beyond a doubt the Hardy Larkspurs are the most beautiful of all the Hardy Garden Flowers; comprising those sparkling shades of blue so much desired in every border, their tall stately forms lending accent and dignity. Soil should be deeply dug and enriched with rotted manure, plants should be mulched from hot sun, and watered in hot weather. After blooming the plant should be cut to the ground, given a dressing of bone-meal, and well watered.

Belladonna. Vivid sky-blue flowers of great delicacy and beauty, $11 / 2$ inches across with white centers, borne in graceful spikes 12 inches long, in great profusion from June to frost. Excellent for cutting. $2 \frac{1}{2} \mathrm{ft}$. $30 \mathrm{cts}$. each $\mathbf{P} ; \$ 2.50$ per $10 \mathbf{P}$.

Formosum. Brilliant deep blue flowers with white centers and long violet spurs in long spikes, set off by handsome foliage. Excellent for borders and extremely fine for cutting. $3 \mathrm{ft}$. $30 \mathrm{cts}$. each $\mathbf{P}$; $\$ 2.50$ per $10 \mathbf{P}$.

Collins Mixed Hybrids. The original stock is raised from seed of the H. J. Jones collection of named varieties, forming an excellent assortment. The colors vary through all shades from lightest blue to dark purple, with blue, black, white, or gray centers. Huge flower spikes, 2 feet long or more, on stems 4 to $8 \mathrm{ft}$. high. June and July, also Sept. and Oct. 35 cts. each $\mathbf{P}$; $\$ 3$ per 10 P; $\$ 15$ per $100 \mathrm{E}$.

E means by Express, see page 67 .

P means by Parcel Post, Prepaid (West of Miss. R. add 10\%).

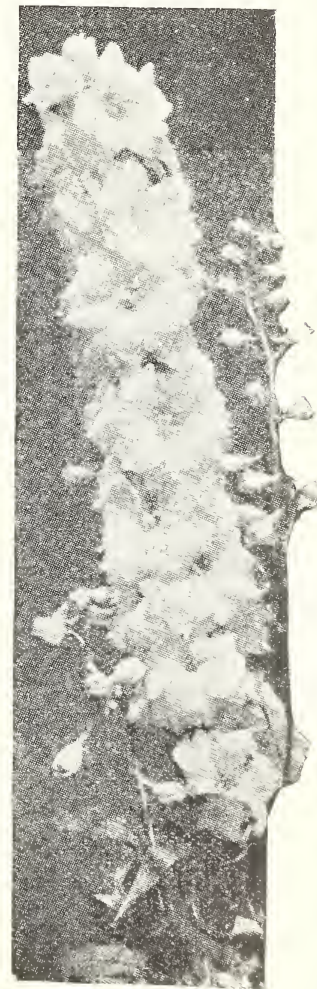

Delphinium 


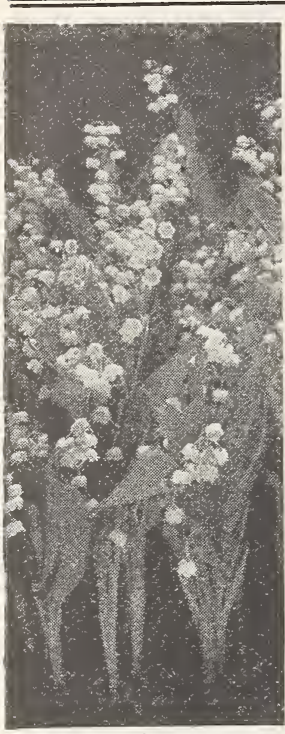

Lily - of - the-Valley

Convallaria Majalis (Lily-of-the-Valley)

These small bell-like flowers, so very fragrant, have endeared themselves to garden lovers for many years. Requiring little or no attention they maintain a fine foliage even when not in bloom. Excellent for ground covering and thrives in shade. Strong clumps of 6 to 10 pips. 50 cts. each $\mathbf{P}$; $\$ 4.50$ per $10 \mathbf{P}$.

\section{Coreopsis (Tickseed)}

Grandiflora. Large bright orange-yellow flowers, borne on graceful stems. Excellent in masses, giving a brilliant note of yellow through the greater part of the summer. Fine for cutting, blooms incessantly. $2 \mathrm{ft}$. June to Oct. $30 \mathrm{cts}$. each $\mathbf{P} ; \$ 2.50$ per $10 \mathbf{P}$.

\section{Dianthus (Pinks)}

Dianthus Allwoodi. (New Perpetual Hardy Pinks.) This is a valuable addition to Hardy Perennials. In perpetual bloom from early spring until late fall, with somewhat larger flowers of better substance, highly clovescented. Fine stems for cutting. Collins Perpetual Pinks assorted (see illustration, bottom of page.) Fine range of colors. 35 cts. each $\mathbf{P}$; $\$ 3$ per $10 \mathbf{P} ; \$ 18$ per $100 \mathrm{E}$.

Dianthus barbatus (Sweet William)

These bright spots of color in the border are fine for cutting. Produce from May to July, dense clusters of 20 to 30 flowers of ten 4 in. across.

Newport Pink. Captivating salmon-pink, a lovely color. 18 inches.

Holborn Glory. Various colors. 18 inches. 30 cts. each $\mathbf{P} ; \$ 2.50$ per $10 \mathbf{P}$.

Dianthus plumarius (Hardy Pinks)

One of the best known old-garden favorites. Excellent for edging the hardy border because of its neat attractive foliage, even in winter. Also fine for rock gardens and for cutting. Prof usion of clovescented blooms in May and June, carnation-like growing 6 to 12 inches high. 30 cts. each $\mathbf{P} ; \$ 2.50$ per $10 \mathrm{P}$.

Collins Finest Mixed Hardy Pinks. A first

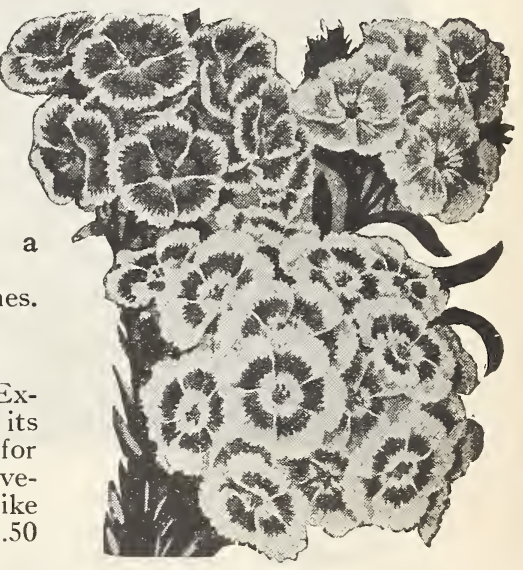

Sweet William rate mixture of fragrant beautifully frilled flowers varying white to pink and crimson. 30 cts. each $\mathbf{P}$; $\$ 2.50$ per $10 \mathrm{P} ; \$ 15$ per $100 \mathbf{E}$.

\section{Dielytra (Bleeding Heart)}

Spectabilis. Fascinating heart-shaped flowers, rosy-red with white petals, hanging delicately along graceful arching stems amid dainty fern-like foliage. Very dainty and charming, a great favorite in old-fashioned gardens, for shady places. 18 inches. Early April through June. 60 cts. each P; $\$ 5.50$ per 10 P.

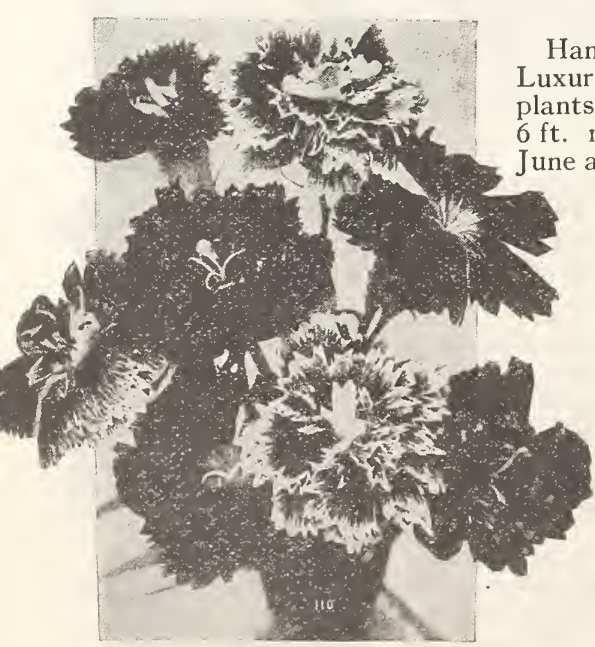

Dianthus

Digitalis (Foxglove)

Handsome spikes of flowers 18 inches long. wuriant foliage clumped at the base of the plants through which the flower spikes rise 4 to $6 \mathrm{ft}$. makes them most effective in the border. June and July.

Giant Shirley Hybrids. A fine new strain raised by the late Rev. W. Wills. Enormous blooms borne on flower spikes towering to 7 feet. Colors, from pure white to deepest rose with interesting chocolate spots. 35 cts. each $\mathbf{P}$; $\$ 3.50$ per $10 \mathbf{P}$.

Gloxiniaeflora. A fine strain of beautifully-spotted flowers, in pink, purple, or white. $30 \mathrm{cts}$. each $\mathbf{P}$; $\$ 2.50$ per $10 \mathbf{P}$.

\section{Funkia (Plantain Lily)}

Subcordata grandiffora. Large, waxywhite, tubular flowers, lily-like and very fragrant, 4 to 6 inches long. Excellent all season long even when not in flower because of its broad glossy leaves. Popular for edges of shrub beds or along paths, valuable for sunny or shady positions. $21 / 2 \mathrm{ft}$. Aug. and Sept. $40 \mathrm{cts}$. each $\mathbf{P}$; $\$ 3.50$ per $10 \mathrm{P}$. 


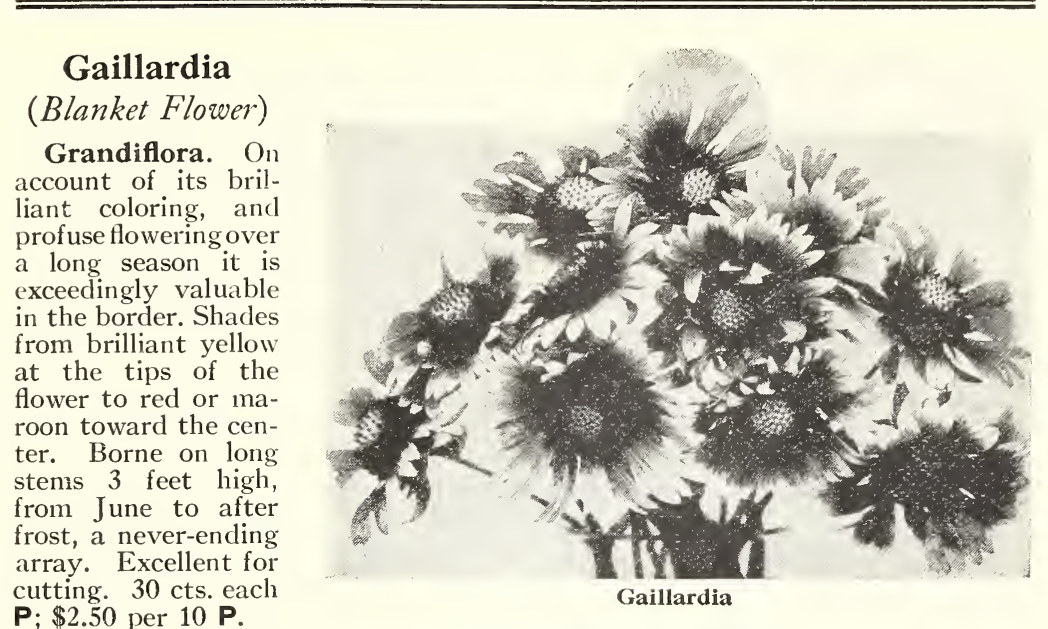

\section{Gypsophila (Baby's Breath)}

Paniculata. The myriads of tiny white flowers borne all over the many branches of the plant produce a charming mist-like effect. On that account quite prized for use in arranging bouquets, softening and garnishing to a surprising degree. $2 \frac{1}{2} \mathrm{ft}$. July and August. $30 \mathrm{cts}$. each $\mathbf{P} ; \$ 2.50$ per $10 \mathbf{P}$.

\section{Helenium (Sneeze Wort)}

Autumnale superbum. Showy and effective at the rear of the border or in front of flowering shrubs. Good for cutting. Blooms through a long season. Broad spreading heads of rich yellow flowers. $4 \mathrm{ft}$. Aug. and Sept. $40 \mathrm{cts}$.

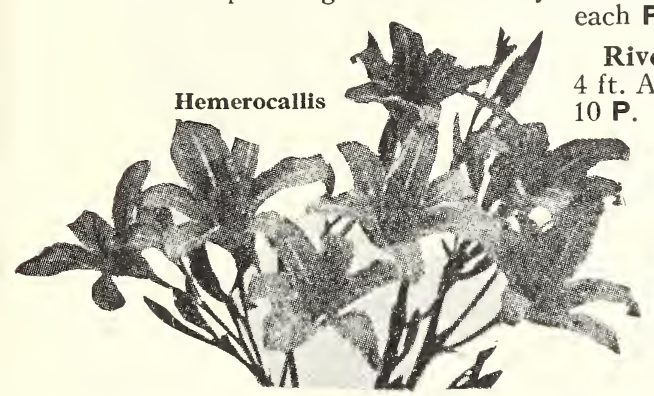

Riverton Gem. Rich mahogany-red flower. $4 \mathrm{ft}$. Aug. and Sept. $40 \mathrm{cts}$. each P; $\$ 3.50$ per 0 P.

\section{Helianthus (Hardy Sunflower)}

Exceedingly effective at the rear of the Perennial border and among shrubs. Very profuse in bloom and excellent as cut-flowers, blooming through July, August and September when flowers are needed.

Mollis. Large golden daisy-like flowers, 3 inches across with downy leafy stems 4 to 5 feet high. 40 cts. each $\mathbf{P} ; \$ 3.50$ per $10 \mathbf{P}$.

Multiflorus plenus. Large semi-double yellow flowers, with quilled petals resembling the cactus Dahlias. Borne in profusion. 4 to $5 \mathrm{ft}$. July to Sept. 40 cts. each $\mathbf{P} ; \$ 3.50$ per $10 \mathbf{P}$.

\section{Hemerocallis (Yellow Day Lily)}

Flava. Very fragrant lemon-yellow lily-like flowers. Excellent in clumps in the border or rock garden, or on the banks of ponds. Fine for cutting. Good succession of blooms through May and June. $2 \frac{1}{2} \mathrm{ft}$. $30 \mathrm{cts}$. each $\mathbf{P} ; \$ 2.50$ per $10 \mathbf{P}$.

\section{Hibiscus (Mallow)}

New Giant Flowering Mallow Marvels. Very striking and effective for planting in groups at the back of the border, or against shrubs, or naturalizing by the water side. Visible for great distances. Large open flowers like huge Hollyhocks, 4 to 8 inches across. Borne in quick succession from Aug. to Oct. Handsome foliage, likes sun or shade. Pink, red, white with deep crimson eye. $35 \mathrm{cts}$. each $\mathbf{P}$ \$3 per $10 \mathbf{P}$.

\section{Hollyhocks}

Fine old garden favorites, unequalled for planting in rows against walls, or at the back of the border. Large, well-opened flowers 5 inches across, held high on spire-like stems sometimes over 7 feet tall. July and August. Cultivate deep, enrich well, add plenty of water. Offered separately by colors.

Double: Red, maroon, white, yellow, rose.

Single: Red, pink, yellow. 35 cts. each $\mathbf{P} ; \$ 3$ per $10 \mathbf{P}$.

SPECIAL OFFER: 1 each of 8 above colors, for $\$ 2.50$ postpaid.

E means by Express, see page 67.

P means by Parcel Post, Prepaid (West of Miss. R. add 10\%).

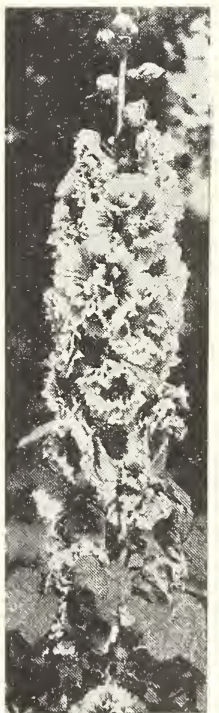

Hollyhocks 


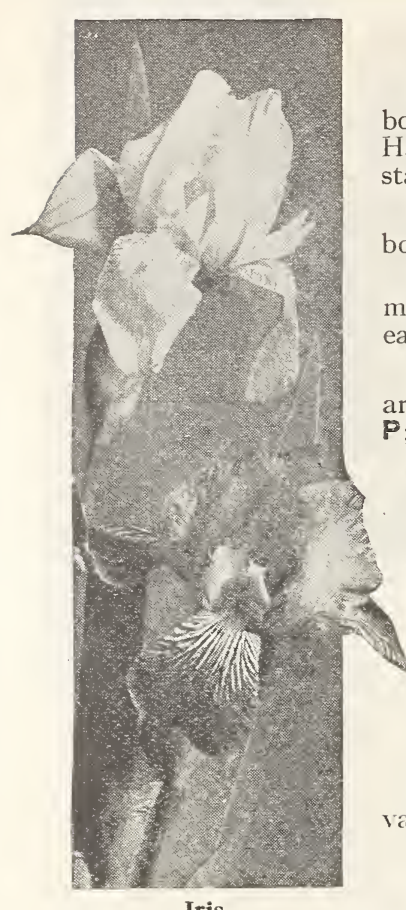

Iris

\section{Iris Germanica (German or Flag Iris)}

Remarkably decorative plants, fine for masses, or in borders. Excellent for cutting. Good in sun or shade. Handsome sword-like foliage, large showy blooms, on stalks 2 to 3 feet tall. May and June.

Lohengrin. An enormous Iris, standards and falls both soft pink. $40 \mathrm{cts}$. each $\mathbf{P}$; $\$ 3.50$ per $10 \mathbf{P}$.

Lorely. Standards of light yellow, falls of rich ultramarine-blue, with veined border of cream. $40 \mathrm{cts}$. each $\mathbf{P}$; $\$ 3.50$ per $10 \mathbf{P}$.

Princess Victoria Louise. Sulphur-yellow standards, falls of rich plum with cream margin. $40 \mathrm{cts}$. each P; $\$ 3.50$ per $10 \mathbf{P}$.

Rhein Nixe. White standards, white margined falls of deep blue-violet. 40 cts. each P; $\$ 3.50$ per 10 P.

Aurea. A rich chrome yellow. Large perfect flower, a beauty. 35 cts. each $\mathbf{P}$; $\$ 3$ per $10 \mathbf{P}$.

Her Majesty. Standards rose-pink, bright crimson falls. 35 cts. each $\mathbf{P}$; $\$ 3$ per $10 \mathbf{P}$.

Pallida dalmatica. Standards of lavender-blue, falls deep lavender. Large fragrant flowers. $3 \mathrm{ft} .45$ cts. each $\mathbf{P}$; $\$ 4$ per $10 \mathbf{P}$; $\$ 30$ per $100 \mathbf{E}$.

SPECIAL OFFER: One each of the above choice varieties (making 7 in the set), postpaid for $\$ 2.45 P$.

\section{Iris Kaempferi (Fapanese Iris)}

Immediately following the German Iris in flowering period. Fine in the border; in front of shrubs, or by water. Excellent for cutting. Huge flowers, ranging from white and blue to deep purple. 2 to $3 \mathrm{ft}$. June and July.

All colors. Contains a fine assortment of varieties embracing all colors. 35 cts. each $\mathbf{P}$; $\$ 3$ per 10 P; $\$ 20$ per $100 \mathbf{E}$.

\section{Lobelia Cardinalis (Cardinal Flower)}

Intense glowing cardinal-red flower spikes 2 to $2 \frac{1}{2}$ feet long. Grow in sun or shade (preferring rich soil) and are unrivalled for fiery brilliance. 2 to $4 \mathrm{ft}$. July to Sept. $30 \mathrm{cts}$. each $\mathbf{P} ; \$ 2.50$ per $10 \mathbf{P}$.

\section{Lupinus Polyphyllus (Lupines)}

Very effective plants with their large stately spikes of pea-shaped, clear blue flowers. Handsome foliage all season. Excellent for cut flowers. $3 \mathrm{ft}$. May and June. 35 cts. each $\mathbf{P} ; \$ 3$ per $10 \mathbf{P}$.

\section{Myosotis (Forget-me-not)}

Palustris Semperflorens. Charming little bright blue flowers with a yellow eye and delicate pink buds. Excellent for carpeting in shady places, borders, or rock gardens. Long period of bloom. 6 to 10 inches. May to Oct." 30 cts. each P; $\$ 2.50$ per 10 P.

\section{Papaver (Poppy)}

Nudicale (Iceland Poppy). Crepey cup-shaped flowers 2 inches across, borne on slender graceful stems 1 foot high. Color-range is from white through yellow, orange and orange-red. Fern-like foliage. April to June; Aug. to Oct. 35 cts. each $\mathbf{P}$; $\$ 3$ per $10 \mathbf{P}$.

\section{Papaver Orientale (Oriental Poppy)}

Large open flowers 6 to 8 inches across. Ranging in gay colors from pale salmon and deep crimson to gorgeous brilliant orange-scarlet. Highly decorative foliage.

Oriflamme. Fine large orange-scarlet, with dark purple eye. Gorgeous. $40 \mathrm{cts}$. each $\mathbf{P} ; \$ 3.50$ per $10 \mathbf{P}$.

Mrs. Perry. Pleasing salmon-rose. $40 \mathrm{cts}$. each P; $\$ 3.50$ per $10 \mathrm{P}$.

Oriental Poppies, Mixed. Excellent varieties of many colors. 35 cts. each $\mathbf{P} ; \$ 3$ per $10 \mathbf{P}$.

E means by Express, see page 67.

P means by Parcel Post, Prepaid (West of Miss. R. add 10\%).

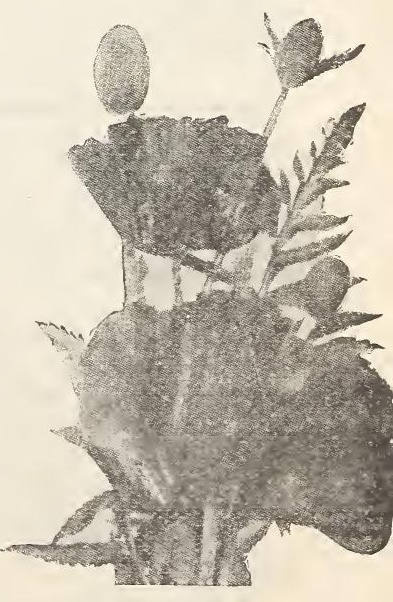

Oriental Poppy 


\section{Peonies}

The stately beauty and wealth of color of Peony blooms make them especially valuable throughout the perennial bed; or alone. Their rich green foliage forms a perfect background for their hues. In planting cover roots not over 2 inches deep.

*Couronne d'Or. Immense ballshaped blooms, snowy white with golden stamens. Late. $\$ 1$ each $\mathbf{P}$.

*Duchesse de Nemours. Early fragrant sulphur-white. Vigorous grower. Free bloomer. 75 cts. each $\mathbf{P}$.

*Edward Andre. Deep brilliant crimson red, shaded black, very large blooms, strong grower. Midseason. Earliest of the dark reds. $\$ 1$ each $\mathbf{P}$.

*Edulis Superba. Light pink with silvery shadings, one of the earliest and best, great favorite for Memorial Day. Very fragrant. $75 \mathrm{cts}$. each $\mathbf{P}$.

Felix Crousse. Brilliant red, fine large blooms. Delightful fragrance, bright and effective. $\$ 1.25$ each $\mathbf{P}$.

*Festiva Maxima. The best white Peony. Pure snow-white with a fleck of carmine in the center. $75 \mathrm{cts}$. each $\mathbf{P}$.

Livingstone. Fine soft rosy-pink, very large, measuring occasionally 8 to 9 inches in diameter. Delightful fragrance, blooms freely. Excellent for cutting. Said to be Crousse's masterpiece. $\$ 1.25$ each $\mathbf{P}$.

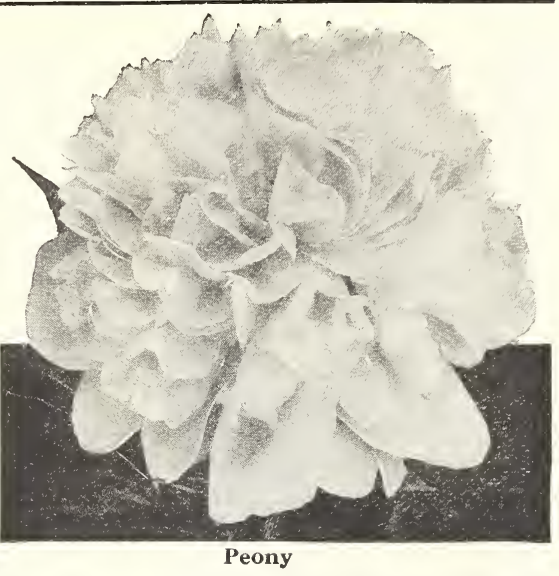

*Madam Calot. Fine, early pink, grows strong, blooms freely. More fragrant and more prolific than any other Peony. $75 \mathrm{cts}$. each $\mathbf{P}$.

Venus. Delicate hydrangea pink, beautifully-formed flower, very pleasing fragrance. Tall grower, fine cutting stems, blooms freely. $\$ 1$ each $\mathbf{P}$.

Rosea Superba. Compact blooms of brilliant deep cerise-pink, perfectly formed. Excellent for cutting. \$1 each $\mathbf{P}$.

Fragrans. Solferino-red with silvery reflex. Compact full flowers. Strong and vigorous. Extensively grown for cut-flowers. $75 \mathrm{cts}$, each P.

COLLINS PEONY OFFER: One each of above starred (*) Peonies, making six in all (all different, whole color range represented) for $\$ 3.85$ postpaid. If west of Mississippi, add 25 cts.

Double Peonies Mixed. Good strong roots. Red, pink or white in choicest mixture 50 cts. each $\mathbf{P} ; \$ 5$ per doz. $\mathbf{P} ; \$ 35$ per $100 \mathbf{E}$.

\section{Phlox}

One of the finest and most valuable Perennials. Very fine for massing on account of its mixed colors and fine habits. Wide color range. Profusion of blooms over very long season. June to Oct. Use in masses 2 to $4 \mathrm{ft}$.

Albion. White with faint red eye.

Bacchante. Fiery pink, crimson eye.

Baron von Dedem. Brilliant cochineal-red, with salmon shadings.

Bridesmaid. White with rose crimson eye.

B. Comte. Brilliant French purple. Gruppenkonigin. Flesh pink with carmine eye.

La Vogue. Rosy pink.

Mrs. Jenkins. Pure white; large.

Rosenberg. Carmine violet with reddish eye.

Rynstrom. Rose pink; very large individual flowers, 35 cts, each $\mathbf{P}$ $\$ 3$ per $10 \mathbf{P}$.

R. P. Struthers. Bright rosy red with crimson eye.

Thor. Very large trusses of dazzling salmon pink flowers overlaid with a scarlet glow. 35 cts. each $\mathbf{P} ; \$ 3.50$ per $10 \mathrm{P}$.

Price of any of above Phlox, except where noted, 30 cts. each $\mathbf{P} ; \$ 2.50$ per $10 \mathbf{P}$; $\$ 15$ per $100 \mathrm{E}$.

SPECIAL OFFER: 1 of each of above 12 kinds for $\$ 2.50$ postpaid. Early Flowering Hardy Phlox

Miss Lingard. This most excellent white variety starts blooming in May and continues through October. One of the most popular sorts grown. Especially good for cutting. $30 \mathrm{cts}$. each $\mathbf{P} ; \$ 2.50$ per $10 \mathrm{P}$.

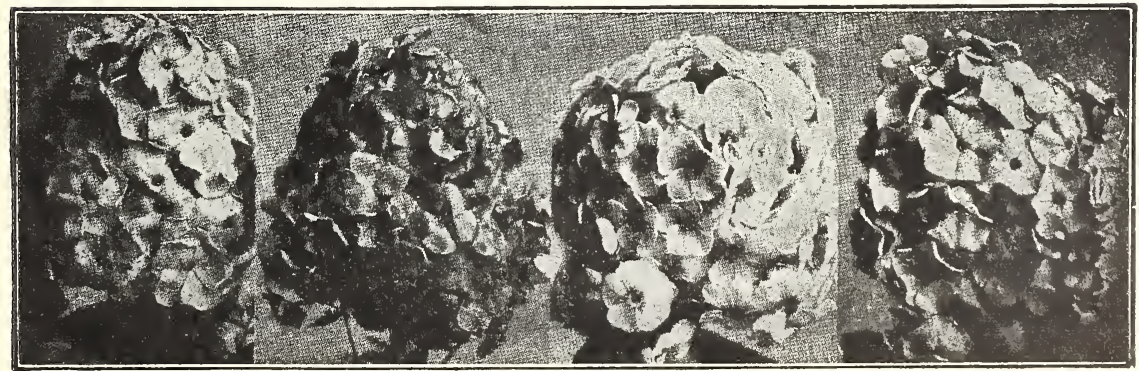

Collins Hardy Phlox-heads often 12 inches long. 


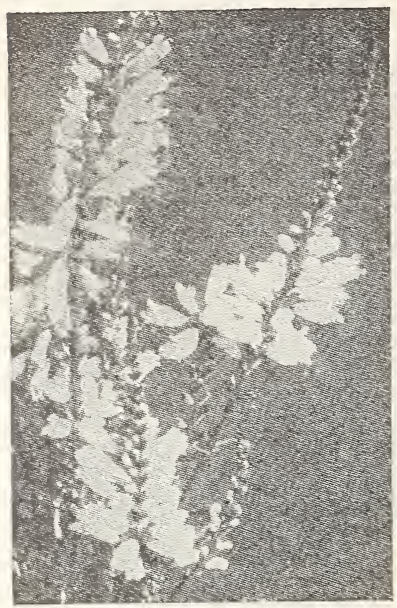

False Dragonhead

\section{Physostegia (False Dragonhead)}

This beautiful summer-blooming plant bears graceful spikes of tubular flowers, resembling delicate snap-dragons. Fine foliage, excellent in front of shrubs and in borders. $4 \mathrm{ft}$. July and August.

Virginica. Long slender spikes closely covered with bright soft mauve-pink flowers. 30 cts. each $\mathbf{P}$; $\$ 2.50$ per $10 \mathbf{P}$.

Virginica alba. Fine white variety. 30 cts. each $\mathbf{P} ; \$ 2.50$ per $10 \mathbf{P}$.

\section{Physalis Franchetti (Chinese Lantern Plant or Winter Cherry)}

Bright orange lantern-like cases, each containing a cherry-like fruit. Valuable for drying for winter decoration. $2 \mathrm{ft}$. Oct. $30 \mathrm{cts}$. each $\mathbf{P} ; \$ 2.50$ per $10 \mathbf{P}$.

\section{Platycodon (Balloon Flower)}

Large wide open white or purple-blue bell-shaped flowers, 2 to 3 inches across, with curiously inflated buds. Great profusion and beauty of bloom. Long blooming period, July to Oct., with handsome, lasting foliage. $2 \frac{1}{2} \mathrm{ft}$.

Grandiflorum. Blue flowers, on slender graceful stems. 30 cts. each $\mathbf{P} ; \$ 2.50$ per $10 \mathbf{P}$.

Grandiflorum album. White variety of above. 30 cts. each $\mathbf{P} ; \$ 2.50$ per $10 \mathbf{P}$.

\section{Pyrethrum (Persian or Painted Daisy)}

A fine old favorite earning new popularity through brilliance and profusion of bloom. Excellent for cutting. Stems nearly 2 feet high. Daisy-like flowers, 2 inches across, ranging from pure white through pink to rich crimson-red; also pale yellow with bright yellow centers. Continuous picking brings more blooms. Excellent in masses. July and through late summer. All colors in mixture. $30 \mathrm{cts}$. each $\mathbf{P} ; \$ 2.50$ per $10 \mathbf{P}$.

\section{Rudbeckia (Cone-flower)}

Excellent for hardy borders, producing profuse array of bright yellow flowers. Hardy, thrives anywhere.

Golden Glow. Double, deep yellow flowers. $6 \mathrm{ft}$. July to Sept. $30 \mathrm{cts}$. each $\mathbf{P} ; \$ 2.50$ per $10 \mathbf{P}$.

Purpurea (see Illustration). Blooms are 4 inches

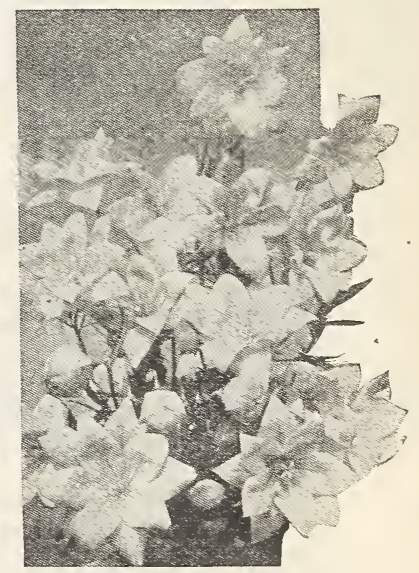

Platycodon across, remarkably colored red with high conical centers of velvety maroon. $3 \mathrm{ft}$. July to Oct. 30 cts. each $\mathbf{P}$; $\$ 2.50$ per 10 P.

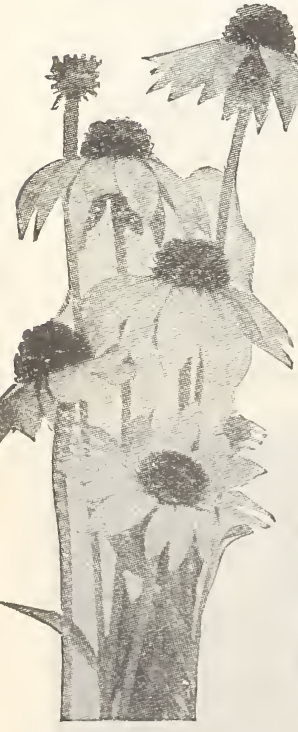

Rudbeckia Purpurea

Salvia (Meadow Sage)

Azurea. Tall straight spikes covered for nearly half their length with lovely sky-blue flowers. 3 to $5 \mathrm{ft}$. Aug. and Sept. $30 \mathrm{cts}$. each $\mathbf{P} ; \$ 2.50$ peir $10 \mathbf{P}$.

Virgata nemorosa. Branching spikes of violet blue continuously from June to frost. Excellent in masses. $2 \mathrm{ft}$. 35 cts. each $\mathbf{P} ; \$ 3$ per $10 \mathbf{P}$.

\section{Sedum (Stone-crop)}

Spectabilis. Fine for front of perennial borders. Immense broad heads of showy rose-pink flowers, often 4 inches across. Evergreen leaves. $11 / 2 \mathrm{ft}$. Aug. to Oct. $30 \mathrm{cts}$. each $\mathbf{P} ; \$ 2.50$ per $10 \mathrm{P}$.

\section{Spiraea (Crimson Meadow Sweet)}

Palmata Elegans. Excellent for borders. On purple stems 3 to 4 feet high are produced terminal clusters of large feathery tiny white flowers. Stems shining through give silvery pink effect. Very fragrant. Handsome dark green foliage beautifully formed. June to Aug. $35 \mathrm{cts}$. each $\mathbf{P} ; \$ 3$ per $10 \mathbf{P}$.

\section{Stokesia (Cornflower Aster)}

Cyanea. This beautiful plant bears large double purple-blue flowers, resembling China Asters, sometimes 4 inches or more across. Blooms from July to November. Fine for use as cutflowers. 1 to $2 \mathrm{ft}$. $30 \mathrm{cts}$. each $\mathbf{P} ; \$ 2.50$ per $10 \mathbf{P}$.

P means by Parcel Post, Prepaid (West of Miss. R. add 10\%).
E means by Express, see page 67 . 
Tritoma (Red Hot Poker, Torch Lily)

Pfitzeri. The extremely brilliant flower spikes of this much-prized bedding plant make it striking in masses, and in front of shrubs. Pointed spikes of rich orangescarlet flowers, on erect stems. 3 to 4 feet long. Gracefully curving leaves. Very free bloomer, fine for cutting. Aug. to Nov. $40 \mathrm{cts}$. each $\mathbf{P}$; $\$ 3.50$ per $10 \mathbf{P}$.

\section{Veronica (Speedwell)}

Longifolia Subsessilis. Showy spikes of intense lavender-blue flowers 12 inches long, rising 2 to 3 feet high from fine, persisting green foliage. Fine naturalized with shrubs. July to Oct. 35 cts. each $\mathbf{P}$; $\$ 3$ per $10 \mathbf{P}$.

Viola Cornuta (Tufted Pansy, Horned Violet)

Jersey Gem. This fine new acquisition to the beautiful Violas cannot be too highly praised. One of the best

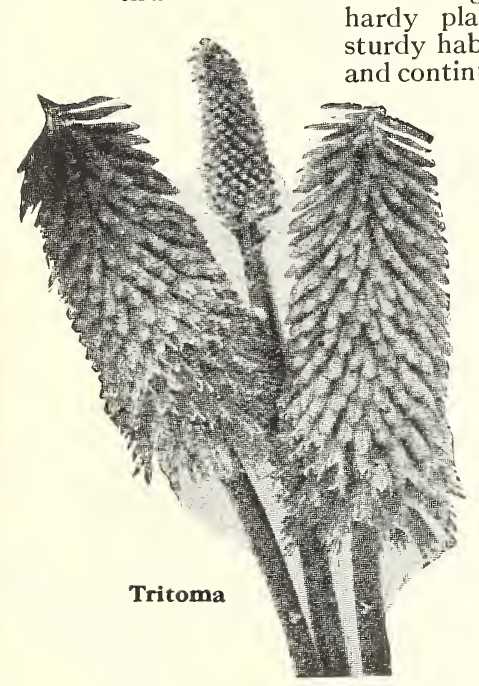

Anchusa Italica

Hardy Aster, Blue Gem

Campanula Carpatica

Centaurea Montana ants of recent introduction, bit of growth. Blooms freely Flowers of royal purple on stems 6 inches long, making

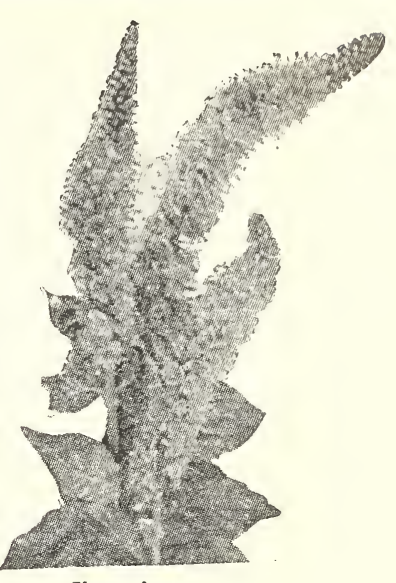

Veronica it splendid for cutting. Use freely for edging and bordering paths. Excellent foliage. Admired by all who see it. A truly fine plant to end our list of 1926 Perennials. Early April to Dec. 50 cts. each P; $\$ 4.50$ per $10 \mathbf{P} ; \$ 40$ per $100 \mathbf{E}$.

\section{Collins Color Gardens}

Color plays such an important part in every garden (a part that is often overlooked) that we have selected the following color groups, bearing in mind ease of culture, profusion of flowers for cutting and blooms from spring until after frost. These groups are offered without changes at the following reduced prices: (See White Garden, page 10)

\section{BLUE GARDEN}

The rarest and most unusual color in the whole flower garden. Here follows an excellent selection of choice blue flowering Perennials in all shades:

Delphinium Belladonna Saliva Azurea Iris Pallida Dalmatica Stokesia Cyanea

Lupinus Polyphyllus Veronica Long. Subsessilis Platycodon Grandiflorum Viola, Jersey Gem

Value \$4.25. We furnish all varieties, \$3.25 postpaid beyond Missis1 of each, making 12 choicest kinds in all for $\$ 3.25$ postpaid sippiadd 35 cts.

\section{PINK GARDEN}

There is a delicate radiance, difficult to describe, about a pink Hardy Garden: full of soft coloring and charm. We offer the following pink-flowering sorts: Anemone

Chrysanthemum, Pink

Dianthus, Newport Pink

Iibiscus, Pink

Hollyhock, Pink

Germanica Iris, Lohengrin Pyrethrum

Dielytra Formosum Phlox, Pink

rethrum Virginica

Sedum Spectabilis

12 varieties. (12 plants in all), for $\$ 2.85$ postpaid beyond Missis-

\section{RED GARDEN}

For bright, ruddy, glowing colors, red-flowering Hardy Perennials have no rivals. Very brilliant in their gorgeous colors. We offer the following red-flowering kinds:
Chrysanthemum, Red
Lychnis Chalcedonia
Hibiscus, Red
Mapaver Oriflamme
Pentstemon Bar. Torreyi Phlox, Red
Rudbeckia Purpurea

Value $\$ 4.05$. We furnish 1 of each of the above $\$ 3$ postpaid beyond Missisred-flowering varieties (12 plants in all), for $\$ 3$ postpaid sippi add $30 \mathrm{cts}$.

\section{YELLOW GARDEN}

Nothing quite takes the place of yellow and orange shades in the Hardy Garden. Warm glowing shades in early spring and late fall bring great cheer and happiness to your garden. Use yellow generously. Brighten your flower border:
Aquilegia Chrysantha
Chrysanthemum, Yellow
Gaillardia Grandiflora
Cen taurea Macrocephala
Helianthus Mollis
Hemerocallis Flava
Helianthus Mollis
Hollyhock, Yellow
Iris Germanica Aurea
Coreopsis Lanceolata

1 of each of

above varieties (making 12 plants in all), for

$\$ 3$ postpaid beyond Missis- 
COLLINS NURSERIES, MOORESTOWN, N. J.

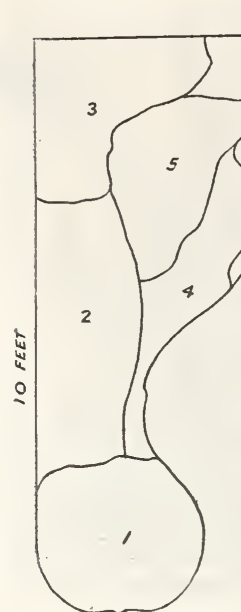

All for $\$ 8.75$

postpaid. Beyond Mississippi $\mathrm{R}$. add $25 \mathrm{cts}$.

12 FEET

\begin{tabular}{|c|c|c|c|}
\hline \multicolumn{3}{|c|}{ Key Quantity } & Price \\
\hline 1 & 1 & Peony, Festiva Maxima.... . . . & \\
\hline 2 & 2 & Hibiscus, 1 red, 1 white. . . . . . . . . . & .60 \\
\hline 3 & 3 & Rudbeckia, G. G. . . . . . . . . . . . & .90 \\
\hline 4 & 4 & Phlox, white .................. & 1.40 \\
\hline 5 & 3 & Delphinium Form.................. & .90 \\
\hline 6 & 4 & 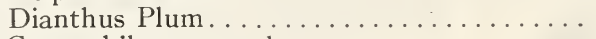 & 1.20 \\
\hline & 2 & Gypsophila pan. and . . . . . . . . . . . . & .50 \\
\hline & 2 & Coreopsis lan . . . . . . . . . . . . . . & .60 \\
\hline 8 & 4 & Hollyhock, single pink. . . . . . . . . . . . & 1.20 \\
\hline 9 & 2 & Platycodon Grand ................... & .60 \\
\hline 10 & 3 & Chrysanthemums, any color . . . . . . . . . & .75 \\
\hline 11 & 1 & Peony, Edulis Superta.................... & .75 \\
\hline
\end{tabular}

Total, $\overline{31}$ plants

\section{Collins "Friendly} Corner" Cluster

The old forgotten "back corner" with this beautiful bed, can be made a cozy, alluring spot the first season. You will enjoy walking out to admire these flowers, and there will be blooms there to cut over a long season. Here too, is a clever setting for a sun-dial, bird-bath or urn.

Key Quantity

Value, $\overline{\$ 10.15}$

\section{Collins "Perennial Pleasure" Border}

This excellent bed of fine proportions presents a beautiful color scheme over a long season, from early spring until late frost. Furnishes a good supply of flowers for cutting. Excellent along the boundary of your lawn.

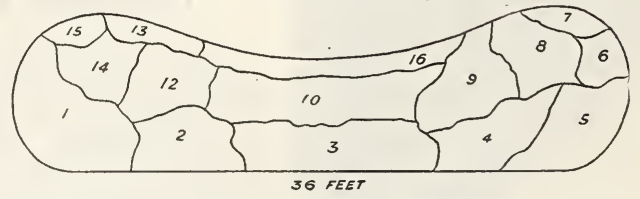

\begin{tabular}{|c|c|c|c|}
\hline Key & Quanti & ity Variety & Price \\
\hline 1 & 3 & Hibiscus, white.. \$ & $\$ .90$ \\
\hline 2 & 3 & Helianthus Mollis & .90 \\
\hline 3 & 5 & $\begin{array}{l}\text { Hollyhocks, } \\
\text { single red.... }\end{array}$ & 1.50 \\
\hline 4 & 4 & $\begin{array}{l}\text { Physostegia Virg. } \\
\text { Alba .......... }\end{array}$ & 1.00 \\
\hline 5 & 2 & Hibiscus, pink... & .60 \\
\hline 6 & 2 & Achillea Ptarmica & .50 \\
\hline 7 & 4 & Forget-me-not . . & 1.00 \\
\hline & 1 & $\begin{array}{l}\text { Peony Festiva } \\
\text { Maxima....... }\end{array}$ & .75 \\
\hline & 4 & Chrysanthemum, & \\
\hline
\end{tabular}

$$
\text { bronze...... } 1.00
$$

$$
\begin{aligned}
& \text { Key Quantity Variety Price } \\
& 104 \text { Delphinium Bel- } \\
& 113 \text { Funkia Sub. } \\
& \text { Grand....... . } 90 \\
& 123 \text { Chrysanthemums, } \\
& 133 \text { Viola Cornuta... } 1.50 \\
& 141 \text { Peony, red...... } 1.00 \\
& 153 \text { Centaurea, blue. } .90 \\
& 163 \text { Papaver nudicale } 1.05
\end{aligned}
$$

Total, $\overline{48}$ plants-Value, $\$ \overline{\mathbf{1 5 . 2 5}}$

Furnished complete for $\$ \mathbf{1 1 . 7 5}$ postpaid. Beyond Mississippi add 25 cts.

\section{Collins "Neighborly" Border}

A suggestion for a neat border planting between your house and your neighbor's, gives beauty as well as privacy to each property. Long season of bloom, fine for cut-flowers, year after year.

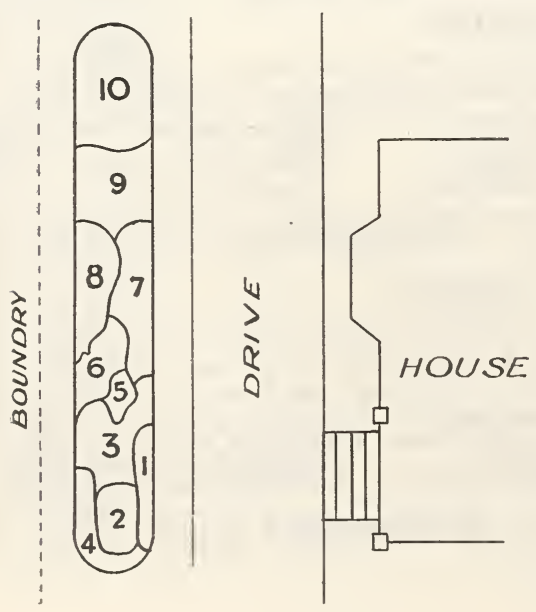

Total, 48 plants Value, $\overline{\$ 12.30}$

All complete for $\$ 9.75$ postpaid. Beyond Mississippi add 25 cts. 


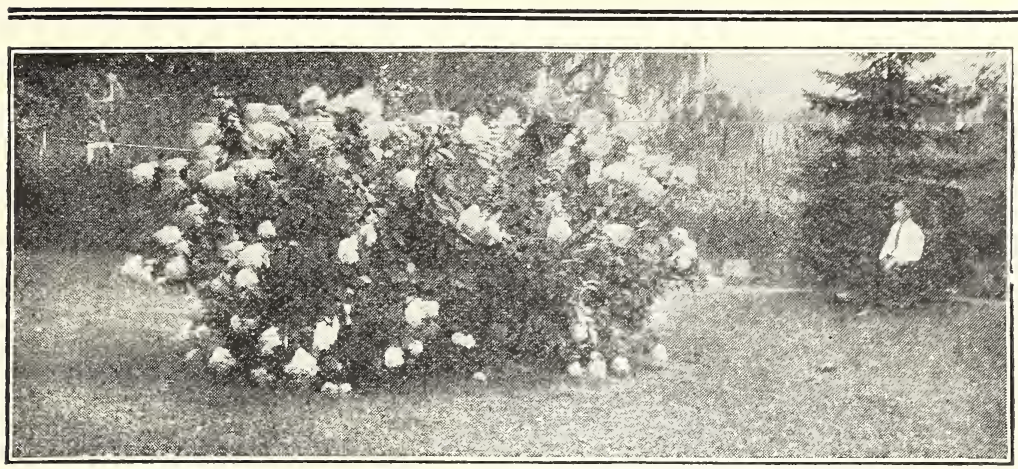

Hydrangea Paniculata Grandiflora (See description page 21)

\section{Collins Flowering Shrubs}

The plants belonging to this fine group are so excellent they have made themselves popular with everyone who knows plants and flowers. From earliest spring all through summer and until long after frost in autumn you find them sending out great quantities of blossoms and flowers, bending in long arching sprays under their load of gay bloom. Then after the leaves and flowers have passed, a gorgeous display of brilliant shining berries glisten on the branches and hang on all winter. Many of these Flowering Shrubs retain their leaves nearly all winter, others cast off their leaves and show beautiful red branches, or bright yellow ones, enhancing the beauty of your winter vistas. All of these shrubs are intensely interesting in leaf, twig and flower formation, and are of great value in furnishing the lawn and foundation of the house properly. Succession of abundant bloom may be had from the many kinds we offer.

"Use your Shrubs," cut their blooms all you desire, carry the flowers into the house and enjoy them in vases and have bouquets. The more they are cut the more flowers are produced. Therefore "use your Shrubs." All are easy to grow, moderate priced and most satisfactory. We furnish bushy plants; they have good roots, they will exceed your expectations. Larger sizes are full of buds to bloom this year. These letters indicate size finally attained by the Flowering Shrubs: L-Large M-Medium S-Small D-Dwarf Abelia Grandiflora (Bush arbutus). A very charming little ever2. green shrub with waxy green leaves, foliage retained practically all
winter. The exquisite white flowers, with faint flush of pink winter. The exquisite white flowers, with faint flush of pink
(just like an Arbutus flower) are delightfully fragrant. They are borne in profusion all summer and fall. Excellent for foundation and border plantings. S. 1 -yr., 12 to 18 inches, 50 cts. P; 2 -yr., 18 to 24 inches, 75 cts. $\mathbf{E} ; 3$-yr., 2 to $3 \mathrm{ft}$., $\$ 1 \mathbf{E}$.

ALTHEA or Rose of Sharon (Hibiscus syriacus).

Very symmetrical, stately, well-formed bushes attractive for their neat habit of growth. Prized for their succession of rose-like flowers. July to October. Extensively used for neat hedges. L.

Bush Form: Double. Colors, Pink, Red, White and Blue. 3-yr., 2 to $3 \mathrm{ft}$., $75 \mathrm{cts}$. E.

Tree Form: Double Pink, Double Red. 3 to $4 \mathrm{ft} ., \$ 1.50 \mathrm{E}$.

BARBERRY (Japanese)-see page 29.

BUTTERFLY SHRUB OR Summer Lilac (Buddelia Veitchiana). Grows rapidly and produces masses of bloom the first season. The blooms, which first appear in July and are continuous until cut down by severe frosts, are a very pleasing shade of violet. Very desirable. Because it is such a heavy producer of delightfully fragrant, beautifully formed flower spikes it wins a place on every property. M. 1-yr., 1 to $2 \mathrm{ft}$., $35 \mathrm{cts}$. P; $2-y \mathrm{r}$, 2 to $3 \mathrm{ft}$., $65 \mathrm{cts}$. E; 4 -yr., 4 to $5 \mathrm{ft}$., $\$ 1.25 \mathrm{E}$.

SPECIAL OFFER: 6 plants, 1-yr., for $\$ 1.95$ P.

CALYGANTHUS FLORIDUS (Sweet Shrub or Strawberry Shrub). Well-known to everyone as an old-fashioned favorite, with its highly-scented, deliciously fragrant, dark crimson chocolate flowers, the kind we used to crush in our handkerchiefs at school. Spring and summer. M. 1-yr., 12 to 18 inches, 35 cts. P; 2 -yr., 18 to 24 inches, 75 cts. E; $3-y r ., 2$ to $3 \mathrm{ft}$., $\$ 1$ E. 


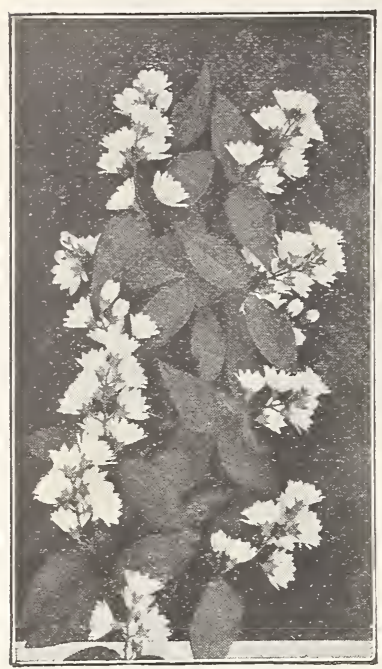

Dainty Deutzia

Callicarpa purpurea (Beauty Fruit). A graceful shrub with long, slender branches, bearing small drooping flowers in August, followed by myriads of shiny violet berries in fall which almost cover the branches. One of the most striking and unusual shrubs. Highly prized for its sparkling berries, and general decorative effect. S. 2- yr. $1 \frac{1}{2}$ to $2 \mathrm{ft} .85 \mathrm{cts}$. E.

Caryopteris Mastacantha (Blue Spirea). Also called Bluebeard. One of the very finest blue-flowering shrubs we have; makes neat compact bushes two feet high; begins to bloom in August and continues loaded with lovely soft violet-blue flowers until frost-an incessant bloomer. Foliage has a peculiar, spicy fragrance. Very effective and satisfactory. D. 1-yr. 12 to 15 inches. 75 cts. $\mathbf{P}$; 2 -yr. 15 to 18 inches. 90 cts. $\mathbf{P}$.

Clethra alnifolia (Sweet Pepper Bush). A very neat-growing shrub with rich green foliage. From July to September. Showy spikes of fragrant white flowers are produced, making a pretty effect. M. 3-yr. $11 / 2$ to $2 \mathrm{ft} .90 \mathrm{cts}$. E.

\section{Cornus (Bush Dogwoods)}

(For Dogwood Trees, see page 38)

Alba (Siberian Dogwood). A stout, strong grower, with very bright red bark, making excellent coloring for winter effects. Porcelain-blue fruits, borne in Autumn. M. 3-yr. 2 to $3 \mathrm{ft}$. $75 \mathrm{cts}$. E.

Stolonifera Aurea (Golden Bark Dogwood). Good companion to above, similar in most respects except the branches are covered with a distinct yellow bark, making it fine for winter effects. M. 3-yr. 2 to $3 \mathrm{ft} .90 \mathrm{cts}$. E.

\section{DEUTZIA}

The Deutzias are all very attractive shrubs, ranging in height from low to very tall varieties, all have an abundance of dainty flowers which cover their branches in the early summer.

Crenata Pink. A fine double-pink Deutzia, a strong grower with flowers tinted rosy-white. June. L. 1-yr. 12 to 18 inches. 35 cts. P; 2 -yr. 2 to $3 \mathrm{ft}$. 75 cts. E; 4 -yr. 4 to $5 \mathrm{ft}$. $\$ 1.25$ E.

Gracilis. Dwarf, attractive, bushy shrub, covered with delicate white flowers in profusion. D. 3-yr. (very stocky) $1 \frac{1}{2}$ to $2 \mathrm{ft}$. $90 \mathrm{cts}$. E.

Pride of Rochester. Sturdy, bushy, upright shrub, covered in May with myriads of beautiful double flowers, blush tinged white. L. $2-y r .2$ to $3 \mathrm{ft} .75$ cts. E.

\section{FORSYTHIA (Golden Bell)}

The most striking shrub in the early spring. Fairly glows under the wealth of rich yellow flowers that cover the whole bush in April and May before the leaves appear. Lights the whole landscape and can be seen afar with its bright warm glow.

Intermedia. A very floriferous variety, graceful and fine. Its erect and arching yellow branches are loaded with bright yellow flowers before its handsome foliage appears. Leaves turn purple in autumn. L. 3-yr. 3 to $4 \mathrm{ft} .90 \mathrm{cts}$. E; 4 -yr. 4 to $5 \mathrm{ft}$. $\$ 1.25 \mathrm{E}$.

Viridissima. This is a fine strong grower with long green branches which are covered with deep yellow flowers. Early M. 1-yr. 12 to 18 inches. 35 cts. $\mathbf{P}$; 2 -yr. 2 to $3 \mathrm{ft}$. 65 cts. E.

I wish to thank you for my last order which arrived safely a few days ago and to tell you I was delighted with my shrubs, etc, previously purchased.

V. K. McC., Annapolis, Md.

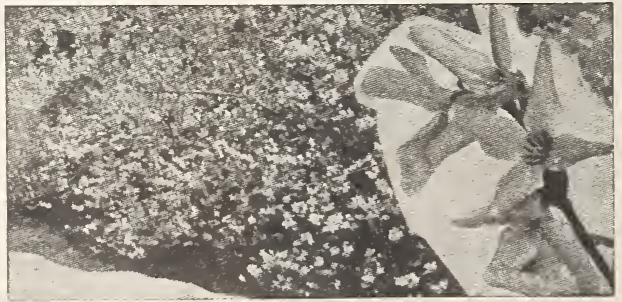

Forsythia

E means by Express, see page 67 .
P means by Parcel Post, Prepaid (West of Miss. R. add $10 \%$ ). 


\section{HYDRANGEA}

No Flowering Shrubs have showier flowers or are better known and appreciated than these large-flowering Hydrangeas. We offer 3 kinds:

Arborescens. HILLS OF SNOW. These sturdy bushes, many branched, are laden with flat flower heads of pure white from June to September. Excellent green foliage, thrives in sun or shade. M. 2-yr. $1 \frac{1}{2}$ to $2 \mathrm{ft}$. 85 cts. E.

Otaksa. THE FAMOUS BLUE HYDRANGEA seen at the seashore resorts. The immense blue heads are very striking, well surrounded by a wealth of rich green foliage. A perfect setting. These plants do well in partly shaded positions. Very popular, a vigorous grower, perfectly hardy. Greatly used in landscape work for shady spots where nothing else will grow. They take away the

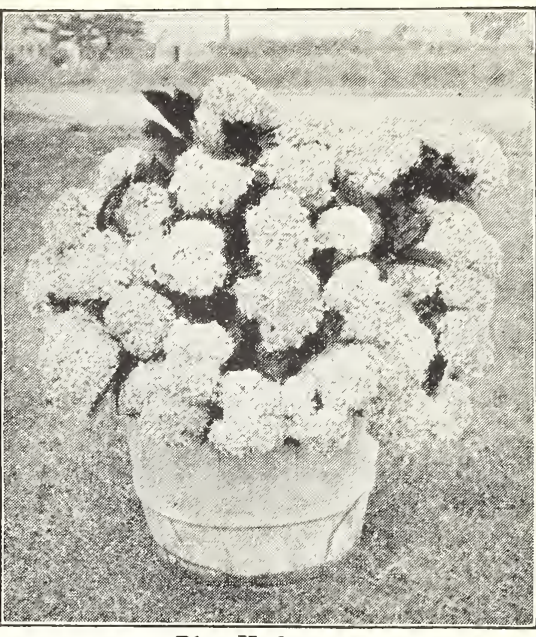

Blue Hydrangea

bareness, and fill the space with long continued succession of bloom even the first season after planting. In full leaf on arrival. S. Strong plants, with ball of earth, $\$ 1$ each $\mathbf{E}$; per doz. \$10 E; special price per 100 .

Paniculata Grandiflora. PEEGEE. This large, white-flowering Hydrangea is a fine old favorite (see photo page 19), undoubtedly the grandest and most beautiful of all the Flowering Shrubs. It forms great panicles or heads (larger than a huge cabbage) of white flowers, changing pink in autumn, and hanging in long arching sprays. A handsome plant, making a striking show from August until December. Cut flowers last many weeks in the house.

Bush Form: 1-yr. 12 to 18 inches. 40 cts. P; 2 -yr. $11 / 2$ to $2 \mathrm{ft} .75 \mathrm{cts}$. P. 4 -yr. 3 to $4 \mathrm{ft}$. $\$ 1.25 \mathrm{E}$.

Tree Form: On upright trunks like small trees, very ornamental. \$1.75 E.

\section{LILACS}

These worthy old-fashioned Shrubs are always prized in every garden, no matter how small the garden may be. Everyone wants lilacs in May. They add beauty and sweetness to all surroundings. $M$ \& L.

Old-fashioned Purple. A strong, vigorous, upright grower with rich, dark green foliage, producing great trusses of deliciously sweet-scented purple flower clusters. Always popular. 3 -yr. 2 to $3 \mathrm{ft}$. $85 \mathrm{cts}$. E; 4 yr. 3 to $4 \mathrm{ft}$. $\$ 1$ E.

Old-fashioned White. Similar to purple, pure white flowers, very fragrant.

Rouen Lilac. A strong grower with spreading branches and large green leaves.

Flowers intense violet-blue and very fragrant. One of the most popular.

Persian Purple. Neat, compact grower. Blooms early. Flowers are large clusters of deep, rich purple and deliciously sweet-scented.

Persian White. Similar to purple, but pure white flowers. Exceedingly fragrant.

Any of above kinds (except where noted), 3-yr. size, 2 to $3 \mathrm{ft} ., \$ 1.25$ E.

COLLINS CHOICE NAMED LILACS (5 leading varieties). Selected from very finest sorts, covering practically whole color range. $3-\mathrm{yr}$. $2-3 \mathrm{ft} ., \$ 1.25 \mathrm{E}$.

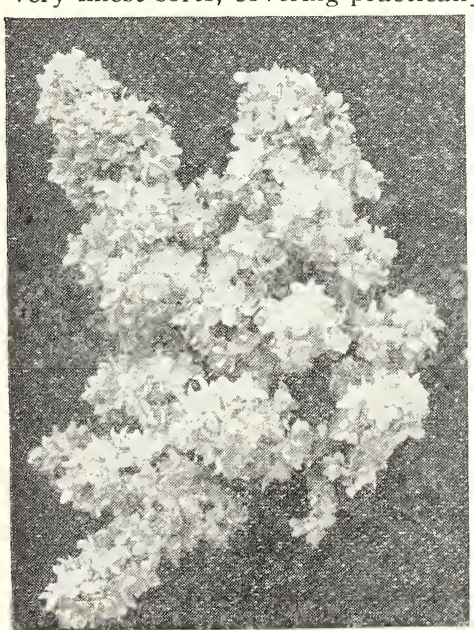

Double Lilac
President Grevy. Double. Beautiful shade of blue.

Mme. C. Perier. Superb flowers of creamy white. Very pleasing.

Souvenir de L. Staeth. Extra fine long panicles of dark purplish-red flowers.

Vestal. Single. Enormous trusses of large-sized flowers of perfect shape. Pure white.

Jacques Callot. Single. Very large panicle delicate rosy-pink.

Charles X. Single. Reddish purple. Michael Buchner. Double. Pale lilac, dwarf.

SPECIAL OFFER: Collins Choice Lilac Collection (5 leading varieties). Excellently rooted and well-branched plants, covering the whole color range, should bloom this first year, 2 to $3 \mathrm{ft}$., bushy plants, or all 5 for $\$ 5.75 \mathrm{E}$.

E means by express (see page 67 )

P means by Parcel Post, Postpaid 


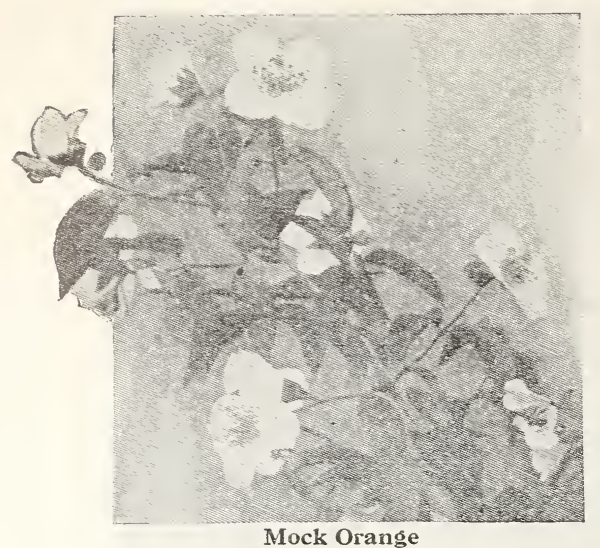

\section{Philadelphus (Mock Orange)}

Excellent ornamental shrubs, vigorous tall growers, bushy, well-branched, fine for shrub banks and screens. All flower very abundantly. Excellent for cutting for decoration.

Coronarius. Vigorous, graceful shrub, with long branches that arch beneath the weight of its deliciously fragrant flowers. The blooms are pure white and are borne in June. Excellent variety. $L$. 2 -yr. 2 to $3 \mathrm{ft}$. $65 \mathrm{cts}$. E; 5-yr. 4 to $5 \mathrm{ft}$. $\$ 1.25 \mathrm{E}$.

Gordonianus. One of the strongest growers, with very large pure white flowers, with some fragrance. Blooms abundantly in July, which makes it very valuable. $\mathrm{L}$. $1-y r .12$ to 18 inches. 35 cts. $\mathbf{P}$.

Grandiflora. Very vigorous, rapid grower, with very large flowers, pure white, in June. Excellent for shrubberies. L. 4 -yr. 4 to $5 \mathrm{ft}$. $\$ 1.25$ E.

\section{SPIREA}

Exceptionally useful and ornamental plants with a wide range of form, foliage and flower. Very desirable on every count.

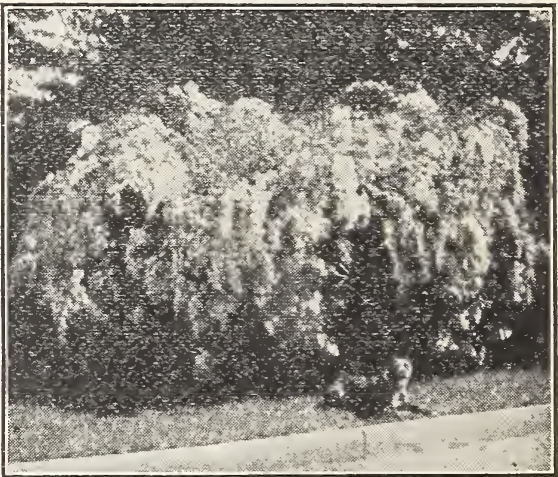

Spirea (Van Houtte)

Anthony Waterer. The perpetual-blooming Red Spirea. A fine, hardy shrub that blooms all through the summer when other flowers are scarce. The large, flat clusters of rich, rosy-red flowers are produced the first season after planting and make an attractive showing up until late fall. Fine for single specimens or as a hedge. Very popular. S. 3-yr. 2 to $3 \mathrm{ft}$. $\$ 1 \mathbf{E}$.

Bridal Wreath. A very graceful shrub with upright branches and dark green shining foliage which changes to brilliant colors in the fall. In May the branches are covered with small double white flowers. One of the showiest of

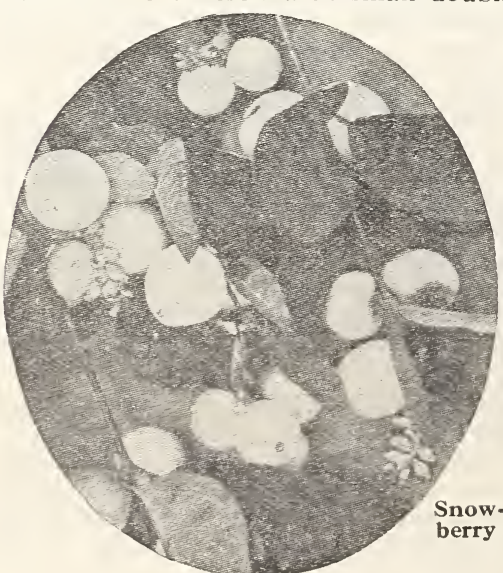

E means by express (see page 67 ) $\mathbf{P}$ means by Parcel Post, Postpaid the Spireas, indeed well-named. M. 3 -yr. 2 to $3 \mathrm{ft} .75 \mathrm{cts}$. E; 4-yr. 4 to $5 \mathrm{ft} . \$ 1.25$ E.

Thunberg. A very graceful shrub with delicate leaves, small and mistlike, that soften the plant, giving it the appearance of a billowy green veil: Myriads of flowers cover the plant in April and May. Beautiful fall-coloring. S. 3-yr. 2 to $3 \mathrm{ft} .75 \mathrm{cts}$. E; 4-yr. 3 to $4 \mathrm{ft} . \$ 1 \mathrm{E}$.

Van Houtte. This spring shrub is an immense bloomer, producing pure snow-white flowers in plume-shaped clusters all over the plant in May and June. Very attractive as a hedge. Grows 5 to 6 feet high. (See illustration.) L. 1-yr. 12 to 18 inches. 35 cts. P; 2 -yr. 2 to $3 \mathrm{ft}$. 65 cts. E; 3-yr. 3 to $4 \mathrm{ft} .90 \mathrm{cts}$. E; $4-y r .4$ to $5 \mathrm{ft}$. (very bushy) \$1.25 E. 
Symphoricarpos Racemosus. (Snowberry). This shrub gets its name from the large white berries, like cranberries, produced in clusters in the fall. Very conspicuous in a shrub planting and a distinct novelty when cut and used in vases in the house. Its attractive little white and pink flowers are produced in July and August when flowers are scarce (see illustration on page 22). M. 2-yr. 12 to 18 inches. 35 cts. P; 3 -yr. 2 to $3 \mathrm{ft}$. $65 \mathrm{cts}$. E.

Symphoricarpos Vulgaris.

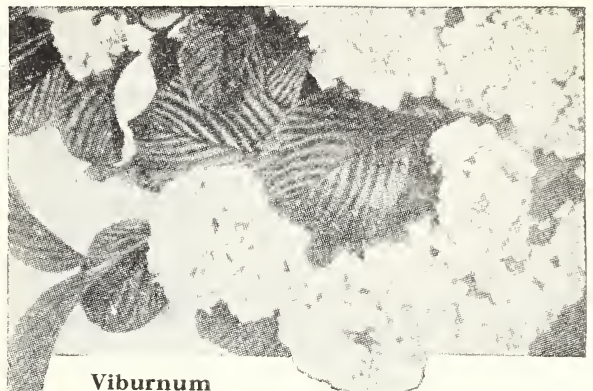

(Indian Currant). Very similar to the Snowberry except that it bears quantities of little, pointed, red berries in the fall which practically cover the top of the bush, the graceful slender branches arching under their load of fruit. Extensively used in shrub plantings and very attractive as hedges or as clumps on the lawn. M 2-yr. 12 to 18 inches. 35 cts. P; 3 -yr. 2 to $3 \mathrm{ft} .65 \mathrm{cts}$. E; 4 -yr. 3 to $4 \mathrm{ft} . \$ 1 \mathbf{E}$.

\section{Viburnum (Snowball)}

Plicatum (Fapan Snowball). The most popular of all of the Snowballs, because it bears a tight compact cluster of flowers resembling a pure, white snowball. These flower clusters cover the bush in spring. The handsome green and purple foliage gives these snowball clusters a rich background of color. M. 2-yr. $11 / 2$ to $2 \mathrm{ft}$. $\$ 1$ E; 3 -yr. 2 to $3 \mathrm{ft}$. $\$ 1.25$ E.

Op. Sterile (Common Snowball). Similar to the Japan Snowball with loose flower clusters and grows slightly taller, blooming in May. $3-y r .2$ to $3 \mathrm{ft}$. $\$ 1 \mathrm{E}$.

\section{WEIGELA}

One of the most attractive and desirable of all Flowering Shrubs. The large trumpet-shaped flowers, resembling huge honeysuckle flowers are produced in abundance and over very long periods of time (see illustration below).

Eva Rathke. This is a remarkably fine shrub. Growing erect and bushy it produces a fine crop of beautiful dark carmine-red flowers all through the summer. Excellent for the shrubbery border. M. $2-y r .11 / 2$ to $2 \mathrm{ft}$. $75 \mathrm{cts}$. E; $3-\mathrm{yr} .2$ to $3 \mathrm{ft}$. $\$ 1 \mathbf{E} ; 4-y r .4$ to $5 \mathrm{ft}$. $\$ 1.50 \mathbf{E}$.

Rosea. Erect, well branched bush with fine foliage bearing showy pink flowers profusely in June. A vigorous grower. M to L. 1 -yr. 12 to 18 inches. 35 cts. P; 3 -yr. 3 to $4 \mathrm{ft}$. \$1 E; 4 -yr. 4 to $5 \mathrm{ft}$. \$1.25 E.

Nana Variegata. This fine variety has light pink flowers, abundantly produced. The foliage is attractively margined creamy yellow. The plant is of bushy and compact growth. S. 2-yr. 1 to $1 \frac{1}{2} \mathrm{ft}$. $50 \mathrm{cts}$. P; $3-\mathrm{yr}$. $1 \frac{1}{2}$ to $2 \mathrm{ft}$. 75 cts. E; 4 -yr. 2 to $3 \mathrm{ft}$. $\$ 1 \mathbf{E}$.

Candida. Vigorous in growth and profuse in bloom. The well-shaped pure white flowers in great clusters come in June, and of ten throughout the summer. $M$. 2 -yr. 1 to $1 \frac{1}{2} \mathrm{ft}$. $50 \mathrm{cts}$. P; 3 -yr. 2 to $3 \mathrm{ft}$. $\$ 1 \mathbf{E} ; 4$-yr. 3 to $4 \mathrm{ft} . \$ 1.25 \mathrm{E}$.

\section{COLLINS “BLOOMING-SIZE”' SHRUB COLLECTION}

Every variety a beautiful one, every shrub very bushy, well-rooted, ready to open into flower this year. Blooms spring till late fall frosts, berries all winter. 2 Spirea Van Houtte, 4 yrs., 4-5 ft. 1 Thunberg's Spirea, 4 yrs., 3-4 ft.

1 Forsythia, 3 yrs., 2-4 ft. 1 Hydrangea Peegee, 2 yrs., $1 \frac{1}{2} 2-2 \mathrm{ft}$.

1 Sweet Mock Orange, 4 yrs., 4-5 ft. 1 Weigela pink, 4 yrs., 4-5 ft.

1 Butterfly Shrub, 4 yrs., 4-5 ft. 4 Japanese Barberry 3 yr. Specimens.

(Note the sizes of these well-developed bushes-note the wide variety range!)

12 Excellent Flowering and Berry-bearing Shrubs.

All have already bloomed and will bloom this year for you. $\$ 7.50$. E.

An extraordinary offer-if bought singly would cost $\$ 10.70$.

\section{COLLINS MAIL-SIZE SHRUB OFFER-6 Shrubs \$1.95 P.}

1 Hydrangea Peegee.

1 Forsythia viridissima.

1 Spirea Van Houtte.

1 Deutzia crenata pink.

1 Weigela pink.

1 Gordon's Mock Orange.

Our customers have indicated their approval of this collection by many "repeat orders."

All 12-18 in. high or more, excellently rooted, with many branches. Some of them will bloom this year.

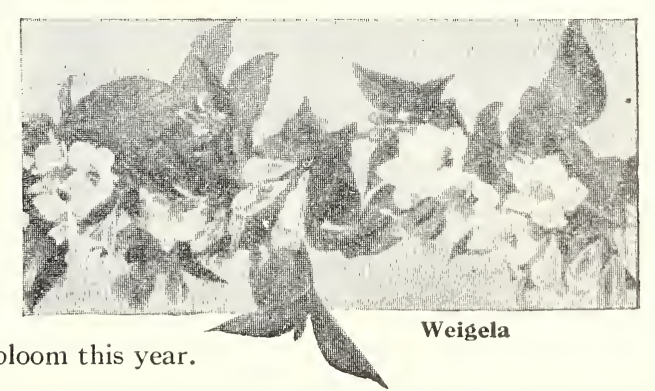




\section{Collins "Better Grade" Dahlias Guaranteed to Grow}

There are very many ordinary kinds of Dahlias offered everywhere today, but these commoner varieties do not have the necessary qualities, do not repay for the labor expended, and are always a disappointment.

But it is not our policy to offer you inferior varieties and you will find on these pages, only "Dahlias of the Better Grade."

We supply our Dahlias in dormant field-grown roots or generous divisions of fully matured field-grown clumps. They are strong, healthy, plump and welldeveloped-full of vitality. Further, we guarantee every bulb to grow, and will replace FREE, on proper proof, any that fail to sprout.

The Dahlia is the "Queen of Fall Flowers," starting to bloom in the summer and continuing for from 10 to 18 weeks, or until cut down by heavy frost in the fall. Dahlias easily win everyone's admiration, they stir up your enthusiasm to a high pitch, and make eager gardeners out of all who come within their spell.

You have only to see Collins Dahlias in bloom to understand why we say, "We are not interested in the cheaper inferior Dahlias flooding the market today."

CLASSIFICATIONS: Cactus Dahlias are like Chrysanthemums. Peony-flowered Dahlias are semi-double, fluffy.

Snow Dahlias are globular, ball-shaped.

Decorative Dahlias are double, full to the center, broad and flat.

WE OFFER ONLY "DAHLIAS OF THE BETTER GRADE."

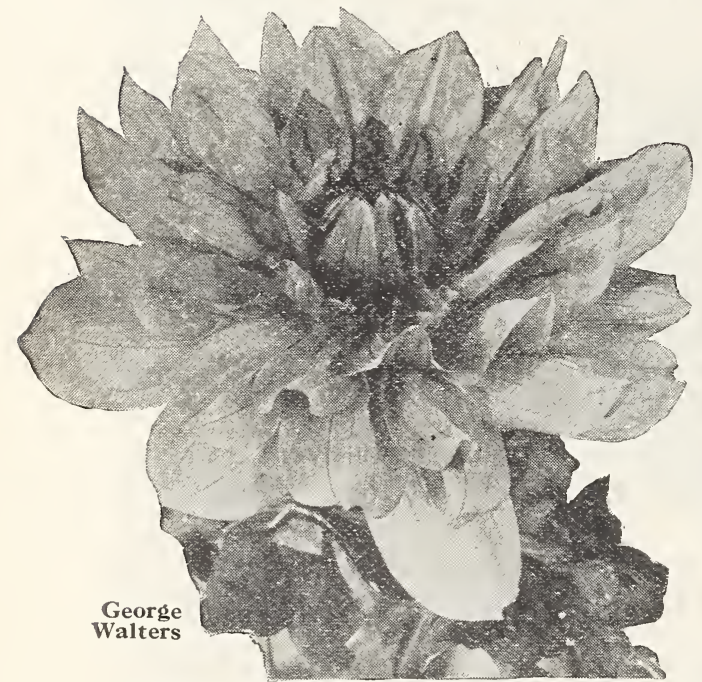

Cultural directions furnished with every order.

\section{COLLINS NEW AND}

RARE DAHLIAS

Bashful Giant. Blooms are gigantic; one of the largest flowering of all Dahlias. Excelling for exhibition, owing to its great size and especially to its beautiful coloring-exquisite apricot with golden suffusions. $\$ 2.50$ each.

Beatrice Slocombe. Early, abundant, blooming continuously, an ideal garden variety. A rich carmine red, blending to old gold and yellow. Each petal is goldtipped, making a most unusual and attractive color combination. Very well-built, large sized flower. $\$ 2$ each.

Cambria. Unusually large flowers, perfectly formed, making one of the finest Decorative Dahlias introduced. Exceptionally free-flowering, with long, stiff, erect stems. Delightfully soft rose-pink, shading to more delicate pink in the center. Considered the best pink. \$1.50 each.

George Walters. This gigantic Hybrid Cactus Dahlia is a popular favorite, being one of the very largest and finest of all Dahlias. It is a beautiful shade of salmon-pink, blending to old gold. The flowers are perfect in form and of good substance, the long stems reaching well above the foliage. Strong, sturdy, growing sort, fine for exhibition, garden or for cut-flowers. \$1 each.

Judge Marean. This giant Decorative Dahlia is of perfect form, and is borne on long, strong stems high above the foliage. The color is marvellous, seeming to change as the flower develops. Colored a glowing salmon-pink, touched with watermelon-red, blending exquisitely to sparkling orange, yellow and gold. Flowers continuously and profusely, and is at its best in August. $\$ 2$ each.

Kalif. This is the largest Hybrid Cactus Dahlia on the market. Is colored a deep rich scarlet that fairly glows. The gigantic flowers are held high above the foliage on strong stems and the plants are sturdy growers. Unsurpassed for exhibition or garden uses, the flower being of perfect form, well-built and of good substance. \$1 each.

Mrs. I. de Ver Warner. Without doubt one of the very best of the Dahlias; extremely strong grower, abundant in bloom, splendid for exhibition or in the garden; a leader among all existing varieties. The bloom is of soft orchid, and refined deep mauve-pink coloring. It has perfect form, is a true type and very impressive. $\$ 1.50$ each. All Dahlias postpaid for prices named above. 
Mrs. T. G. Bemister. A very desirable acquisition to every worthwhile collection. This splendid flower of the Decorative Class, is especially attractive, being colored a bright carmine-red, blending to golden yellow at the center, with occasional tips of white. It is early and continuous in blooming and produces its gigantic flowers abundantly. Some of the plants produce semi-double flowers, showing the golden yellow center prominently. Quite new and rare, and one we must highly recommend (see photo). \$5 each.

The Emperor. A magnificent prize-winner of highest quality. Enormous in size. Perfect form. Beautiful deep maroon color. Its extra long stems and long flat petals make it an exceptional variety. So in-

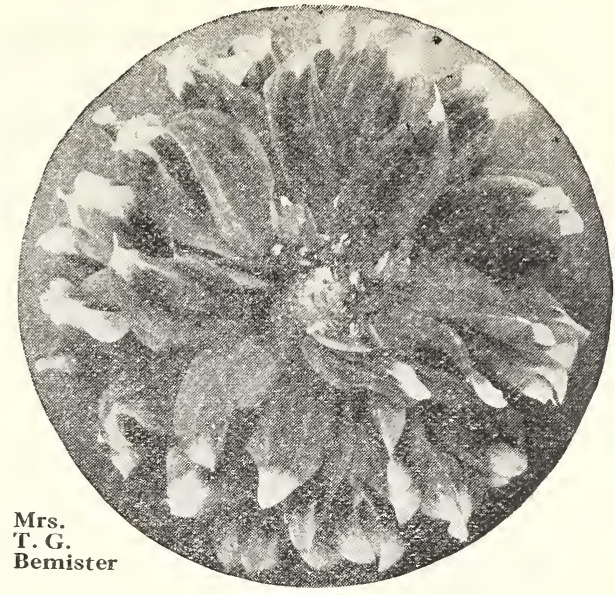
tense is its color that it does not spot under any weather conditions. \$2 each.

COLLINS PRIZE WINNING OFFER: One of each of the above 9 kinds (each carefully labelled), making a splendid collection, for $\$ 16.75$ postpaid. If west of Mississippi add 10\%. (Value $\$ 18.50$ ).

\section{Collins Six Giant Dahlias}

Ben Wilson. A grand Decorațive Dahlia. Large size. Flowers on strong stems. It is a warm orange-red color, yellow-tipped. Is exceptionally fine for exhibition. \$1 each.

Bertha Story. An exceptional Decorative Dahlia. Splendid for exhibiting. It produces enormous flowers on long graceful stems two feet long or more. The flowers are a beautiful rose-pink color, with occasional white petals which add to their attractiveness. It is highly recommended. $\$ 1$ each.

Elizabeth Slocombe. Fine Decorative type. Mammoth flowers on long, sturdy stems. Opens as rich brilliant purple garnet, matures as lighter garnet. The largest and best of its color, and the most highly recommended. A strong vigorous grower, making a splendid show in the garden. Fine to exhibit or cut. 50 cts. each.

Millionaire. A very popular Decorative Dahlia, in great demand. Flower is a pleasing lavender color, shading to white at the center. One of the very largest Dahlias in existence. Dwarf grower. \$1 each.

Paul Michael, or California Gold. One of the largest and most beautiful of all Decorative Dahlias. Has twice captured the prize for the largest Dahlia in California Exhibition Shows. Its color is pure gold shading to deep buff orange. Blooms early, continuously and abundantly. Ideal for exhibition or garden use. Plants are strong and sturdy. If shaded a week before showing a flower of even more majestic proportions can be created. $\$ 1.50$ each.

William H. Slocombe. Authorities consider this the largest and best pale yellow Decorative Dahlia. It produces flowers of gigantic size, from six to eight inches under ordinary conditions, and can be grown much larger. It is a clear primrose to sulphur-yellow color. Recommended as the best yellow for either exhibition or garden purposes. \$1 each.

SPECIAL OFFER: We will furnish 1 each of the 6 giant kinds above $(6$ roots in all), for $\$ 5$ postpaid. This superb collection will prove a winner from every point of view. Every Dahlia in it will produce flowers from five to eight inches in diameter, and several of them will grow flowers ten to twelve inches in diameter if given proper care. We predict this collection will outsell all the others as there is a

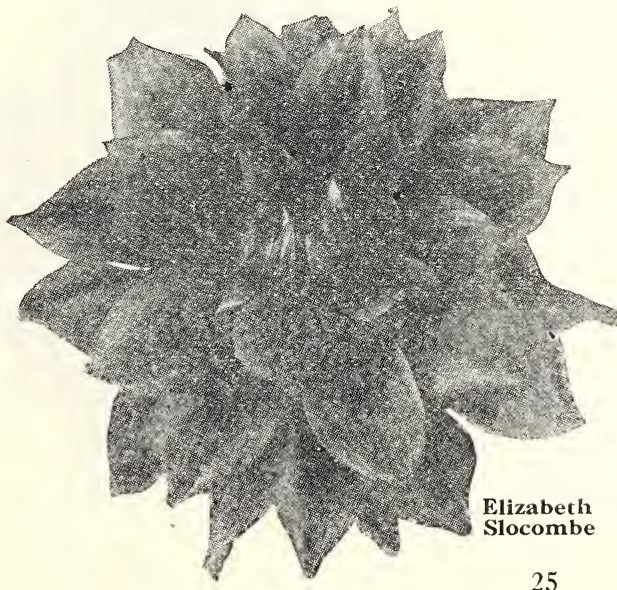
heavy demand for this type of Dahlia

\section{COLLINS SURPRISE COLLEGTION}

A splendid collection of selected Dahlias, calculated to surprise you very pleasantly when their blooms unfold: This collection includes four Decorative Dahlias-a pink, a buff, an almost black, and a silvery rose a pale yellow Peony-flowered variety, and a crimson Cactus, a very choice collection:

Delice, Mrs. George Stumpp, Noir Alvarez, President Harding, Rene Cayeux, Rose Gem.

One of each of these (see descriptions on page 26), making 6 roots in all, postpaid for $\$ 2$.

All Dahlias postpaid for prices named above. 


\section{Collins "Favorites of All Classes"}

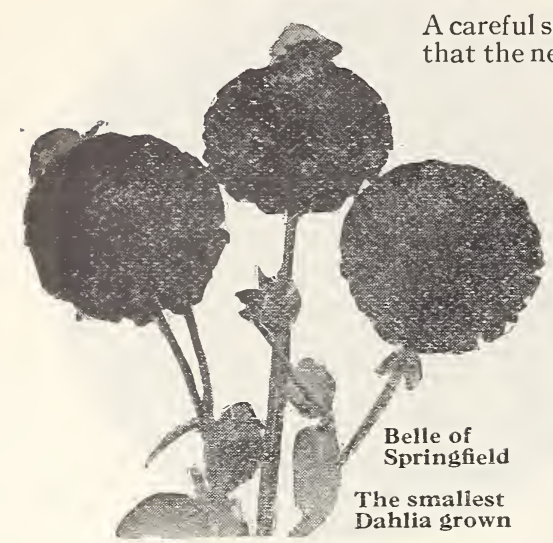

A careful selection of Dahlias which are so favorably known that the newest introductions find it hard to win the prizes.

Belle of Springfield. The smallest dahlia grown, much desired for buttonhole bouquets. Very beautiful crimson-red. 50 cts. each.

Bertha Bailey. A beautiful Holland introduction in Peony-flowered Dahlias. Very long petals. Color is a blending of scarlet-red and golden-yellow. Excellent both for exhibition and garden purposes. $50 \mathrm{cts}$. each.

Darlene. The finest cut-flower Dahlia to date. An entrancing shade of live shell-pink with a dainty center of white. Blooms very early, and abundantly. In uniformity and perfection of flowers, it stands out above all others in the decorative class. Long, sturdy stems. 35 cts. each.

Delice. The brightest pink Decorative Dahlias, a florist's favorite. Good size flowers, produced high above the foliage. Rose-pink, suffused with lavender-pink. 35 cts. each.

Dr. Peary. Beyond doubt the best dark Peony-flowered Dahlia-a very large rich velvety maroon. Abundant bloomer. 50 cts. each.

Ferna. Very large fluffy flowers, produced early and abundantly. A fine Peony-flowered sort, most delightful shade of rose-pink. $25 \mathrm{cts}$. each.

Frank A. Walker. An extra fine cut-flower variety, equally valuable as a garden Dahlia. One of the earliest in bloom, has flowers about the size of Delice and blooms three weeks ahead of it. Flowers continuously and abundantly. A very beautiful soft shade of lavender-pink. $25 \mathrm{cts}$. each.

Lavinia. Exceptionally fine Incurved Cactus Dahlia. An excellent specimen, of large size and unusual formation. The long, very narrow petals are tightly quilled, and are so incurved and interlaced that they almost meet in the center, making an attractive and novel flower. A beautiful coppery-red and apricotcrimson. Most abundant bloomer of the Incurved Cactus type. $50 \mathrm{cts}$. each.

May Tilden. Extremely popular on account of its rich coloring of autumn shades. Flowers are orange and buff, with tracings of bronze and dark bronze. A good grower, everywhere considered a very valuable sort. $50 \mathrm{cts}$. each.

Mrs. C. D. Anderson. A very beautiful Hybrid Show double Dahlia, with a fine coloring of rich purple-crimson. Good grower, large flowers. 50 cts. each.

Mrs. George Stumpp. This Decorative Dahlia has a very large flower, exquisitely blending amber and buff. Stems very long and sturdy. One of the strongest favorites among autumn-tinted Dahlias. 75 cts. each.

Mrs. M. W. Crowell. A Peony-flowered Dahlia of a most pleasing shade of orange and yellow. Abundant bloom on long, strong stems. 35 cts. each.

Montague Wootan. A fine Pompon Dahlia, of a very good crimson-lake color. One of the best of the class. 35 cts. each.

Noir Alvarez. A handsome Decorative Dahlia. Exceptionally fine, of large size, continuous and abundant in bloom. A very rich deep velvety ox-blood-red, the best dahlia of this color to date. Plants are tall, and vigorous; flowers held high above foliage. Very fine for garden or exhibition use. $50 \mathrm{cts}$. each.

Pierrot. Beautiful Incurved Cactus type. An extra fine English importation, Large sized flowers. A popular shade of amber-bronze, occasionally tipped white. Excellent for garden or exhibition. $35 \mathrm{cts}$. each.

President Harding. A fine Peony-flowered Dahlia, producing abundantly fine large blooms of soft clear yellow. $50 \mathrm{cts}$. each.

Rene Cayeux. One of the older varieties that retains its deserved popularity, because its clear rich crimson flowers literally cover the plant from early summer until late fall. Excellent cactus type. Very early. $50 \mathrm{cts}$. each.

Rose Gem. A Decorative Dahlia of distinction, abundantly producing large blooms of silvery rose-pink. $25 \mathrm{cts}$. each.

Starling. An exceptionally free-flowering Collarette Dahlia. Blooms are a very bright, intense crimson with a bright white collar. 35 cts. each.

Storm King. A very attractive Show Dahlia with large, ball-shaped globular flowers of pure white. 25 cts. each.

Any of the above Dahlia favorites mailed postpaid for the prices named. (See Collection Offers, pages 25 and 27 .)

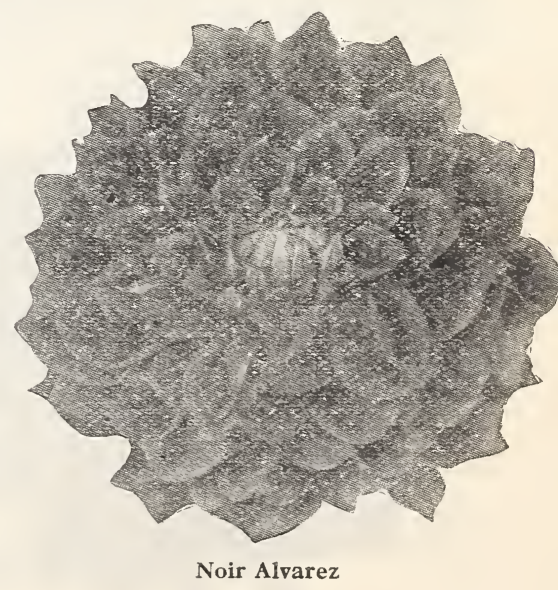




\section{Collins Twelve Superb Dahlias}

Twelve exceptionally fine Dahlias recently introduced, all of which stand out because of their distinctive qualities.

Advance. A very bright fiery scarlet, with a slight yellow blending at the base of the petals. A very large flowering Cactus Dahlia. $50 \mathrm{cts}$. each.

Bertha McAteer Dieh1. Good size flowers, very fine for cut-flower use. Very strong wiry stems holding soft canaryyellow flowers erect. A very desirable Decorative. $50 \mathrm{cts}$. each.

Chieftain. This Decorative is one of the finest two-colored Dahlias, buff, striped and splashed crimson. Some plants produce solid crimson blooms. A remarkably beautiful Dahlia, whether solid crimson or variegated. Produces large flowers on stiff long stems, excellent for cutting. Ideal for exhibition or garden use. $50 \mathrm{cts}$. each.

Debutante. An especially fine Peony-

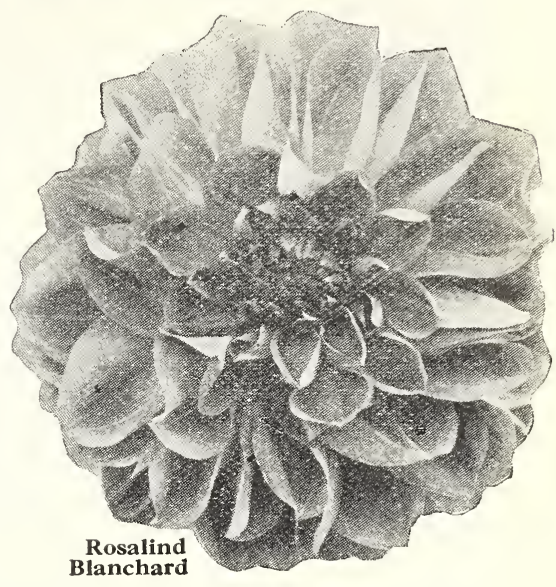

flowered Dahlia. A most exquisite and beautiful shade of salmon-pink, yellow blended. Blooms profusely. $50 \mathrm{cts}$. each.

Effective. Cactus Dahlia of bright primrose shaded amber, blooms continuously and abundantly. Favorite for cut-flowers and for garden uses. $50 \mathrm{cts}$. each.

John Green. Long-pointed petals of scarlet and gold make this a very attractive Peony-flowered Dahlia. Very prof use in blooming. $50 \mathrm{cts}$. each.

Lotona. This Holland Decorative is rich in autumnal coloring, an unusual blending of orange, buff and yellow. Extra fine for cut-flower purposes. Produces abundantly, on erect, sturdy stems. $50 \mathrm{cts}$. each.

Le Grand Manitou. A broad massive Decorative of great depth. White flowers striped, splashed and blotched with a rich violet-purple. Occasionally very fine solid deep purple flowers are produced. Really phenomenal. Very desirable for exhibition and garden uses. Dwarf grower. $50 \mathrm{cts}$. each.

Maude Adams. A fine show type. Pretty pink-tinted white. One of the very best florist's Dahlias. Blooms continuously and abundantly. $50 \mathrm{cts}$. each.

Mina Burgle. This is the finest brilliant glowing Scarlet Decorative Dahlia for cut-flowers and for garden purposes. Large flowers, perfect in formation and produced very abundantly. Stems long and wiry. 50 cts. each.

Rosalind Blanchard. A Decorative Dahlia. Has well formed flowers of tightly quilled florets, of a charming shade of deep-rose-pink. Flowers are produced abundantly on good stems. Plants are tall and sturdy. $50 \mathrm{cts}$. each.

Sunbeam. A very distinct, attractive Decorative Dahlia, quite different from any other, having inside of each petal of the flower several smaller petals, making this a good novelty. A bright carmine-red, the pointed and twisted tips of the petals being touched with gold. $50 \mathrm{cts}$. each.

Any of above varieties postpaid for price named after each, or,

SPECIAL OFFER: One each of COLLINS TWELVE SUPERB DAHLIAS (listed above, making 12 roots in all) for $\$ 5$ postpaid. If west of Mississippi add $10 \%$ for postage. This is a list of really worth-while dependable Dahlias, selected to give you 12 varieties of exceptional merit.

\section{Collins Dollar Dahlia Collection}

Read descriptions on preceding pages. Consists of a pink and white Decorative, a lavender Decorative, an orange Decorative, a deep maroon Pompon, a yellow Peony-flowered and a pure white, ball-shaped Dahlia.

Darlene, Frank A. Walker, May Tilden, Montague Wootan, Mrs. M. W.

Crowell, Storm King.

The above group of 6 choice varieties ( 6 roots in all) for $\$ 1.00$ postpaid.

\section{Collins Novelty Collection}

Includes those varieties which are unusual, distinctive and highly interesting. The smallest Dahlia grown; a scarlet and yellow Holland Peony-flowered with long petals; a velvety maroon Peony-flowered; a rose-pink Peony-flowered; Incurved Cactus in cinnamon shades; giant purple, ball-shaped; an exceptionally attractive amber Cactus; and a Collarette Dahlia are all in this list. Descriptions of them are on preceding pages.

Belle of Springfield, Bertha Bailey, Dr. Peary, Ferna,

Lavinia, Mrs. C. D. Anderson, Pierrot, Starling.

OUR SPECIAL OFFER: We will furnish 1 each of the above 8 excellent kinds (making 8 roots in all) for $\$ 3$ postpaid.

\section{Collins Dahlias in Mixture}

This collection contains a fine assortment of very good kinds representing all colors and types. 6 roots for $\$ 1$ postpaid; 10 roots for $\$ 1.50$ postpaid. 


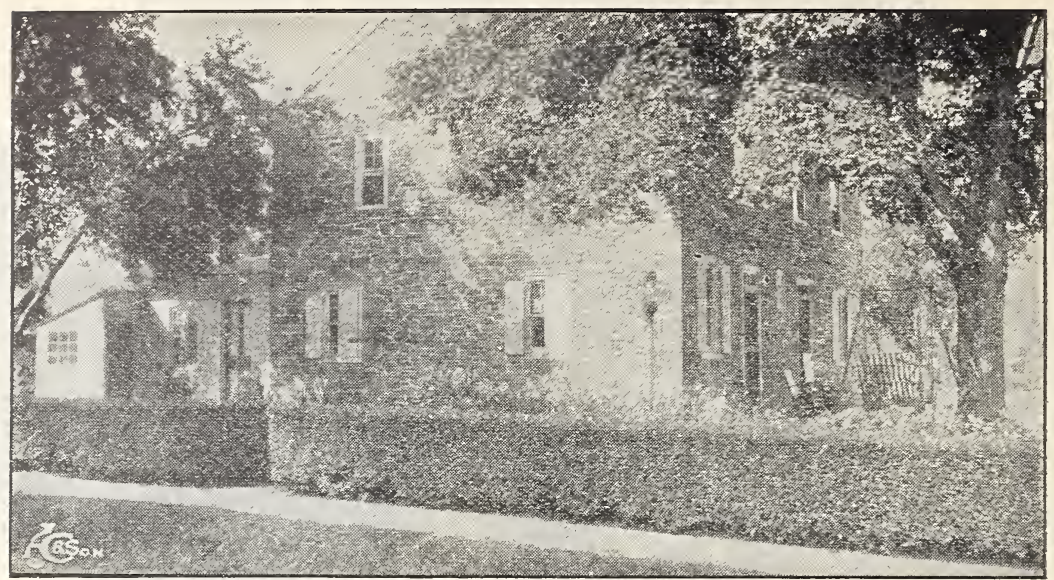

This attractive photograph was sent to us by one of our customers, unsolicited by us. He says: "On October 22, 1915, I received 900 California Privet plants from you, and the hedge which they form is certainly fine. I will enclose cards showing hedge and house. If you can use them, you are welcome to them. I am well pleased with the hedge. It has grown $2 \frac{1}{2}$ feet wide and $2 \frac{1}{2}$ feet high in 4 years."-JOHN W. G. YOUNG, PA.

\section{Collins California Privet}

What is Collins California Privet? It is a strong healthy plant with glossy green leaves, and when mature it bears small clusters of white flowers.

For what are the plants used? For hedges, for screens, for planting between the lawn and the street, for clumps on the lawn, for arches, for flanking walk entrances, and for one hundred other purposes.

Do you just plant them? Yes, that's all, set them out in a single row (or if you prefer in a double row) six inches a part in the row, and if in double row plant them staggered. This requires two to the foot, or 100 plants for 50 feet. Tramp the earth well about the roots and trim the hedge off even on top.

Do they get a disease? No. Nothing attacks these rugged plants. Neither insects nor disease find lodging here.

Are Collins Privet Plants healthy? Yes. They are grown on strong Jersey soil, we keep them well farmed which kills the weeds and makes the plants grow fast, and we give them liberal helpings of fertilizer and manure. That ought to make them healthy and happy, and they are.

So popular has this California Privet Hedging become that we venture to say that there is more of it planted each year about the properties in the eastern section of the United States than all other varieties of hedging material put together.

\begin{tabular}{|c|c|c|c|c|c|}
\hline & & REDU & PRICES & & \\
\hline & 100 & 1000 & & 100 & 1000 \\
\hline 2 to $18 \mathrm{incl}$ & 4.5 & $\$ 40.00$ & 3 to 4 feet & $\$ 10.50$ & $\$ 100.00$ \\
\hline 24 inc & 6.00 & 55.00 & 4 to 5 feet & 15.00 & 140.00 \\
\hline 3 feet & 8.00 & 75.00 & 5 to 6 feet. & 20.00 & 190.00 \\
\hline
\end{tabular}

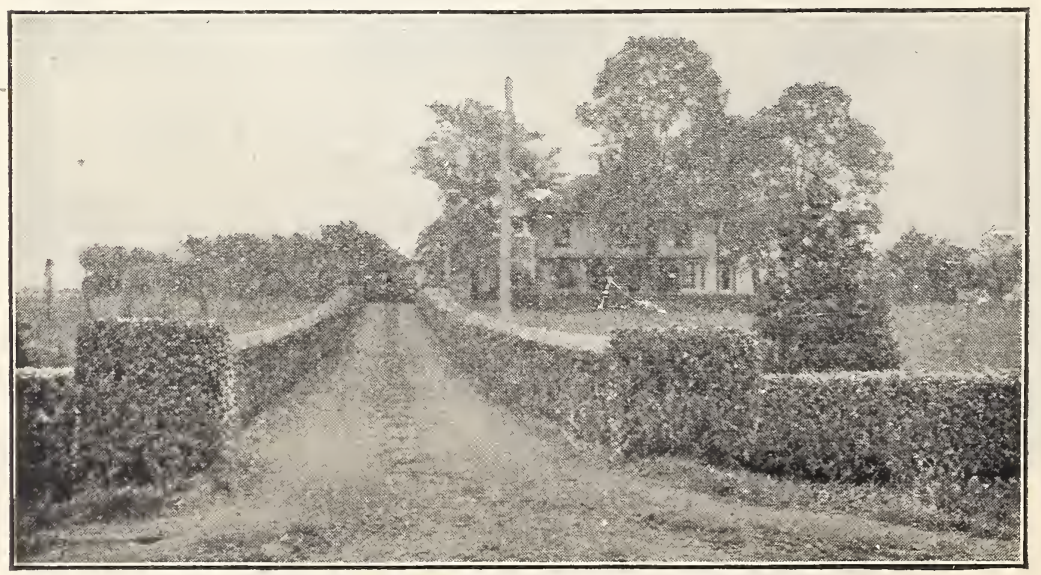

California Privet bordering farm approach 
ARTHUR J. COLLINS \& SONS, INC.

\section{FIFTY THOUSAND COLLINS-GROWN SELECTED QUALITY JAPAN BARBERRY PLANTS}

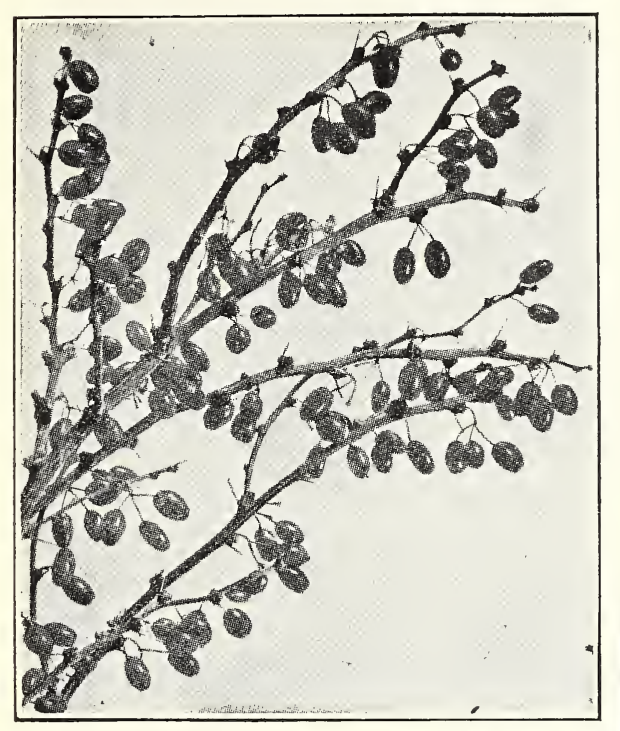

The brilliant Red Berries brighten earliest birds in Spring.

\section{"If Winter Comes"}

and leaves your garden more desolate each week-if you long for a dwarf hedge that will supply the touch of brightness throughout the Winter, that will bring the robins to your garden to feast in early Spring before the worms are above ground, investigate this Barberry offering NOW.

No Disease-No Insects attack this species of Barberry. Highly recommended by all authorities.

\section{Collins \\ 50,000 \\ Japan \\ Barberry \\ Plants-}

The

Ideal

Hedge

Plants-

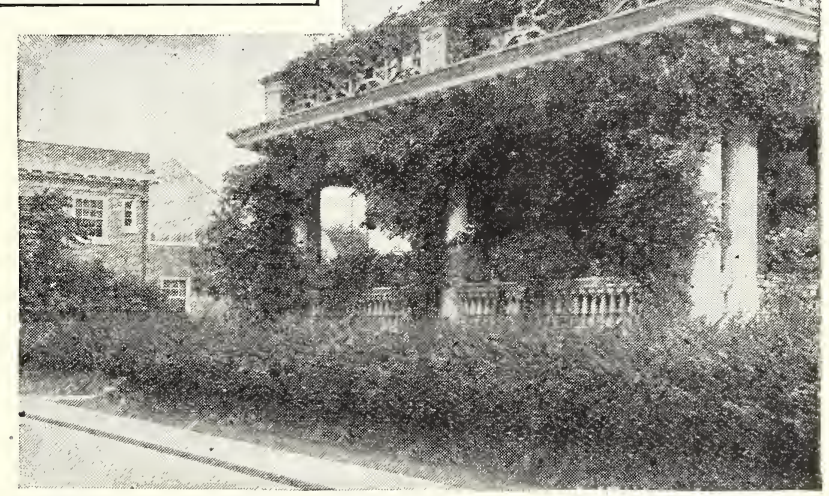

Showing the Summer Charm of a Barberry Planting Around a Vine Covered Porch

For a dwarf hedge Japan Barberry is ideal. The branches are gracefully curved, and grow so thickly they make a dense hedge. You need trim it only four or five times a year to keep it low, bushy and compact. Plant one foot apart.

Throughout the summer the foliage is a beautiful green and very pleasing, changing to a fiery blaze of bright orange and scarlet in autumn, rivaling the changing maples and oaks. In winter its brilliant red berries shine gaily through the glistening ice on the branches and are the delight of the earliest birds in spring which seek them eagerly.

Cluster these attractive plants at your walk entrances or at your porch; they are most adaptable. Our plants are well-rooted, well-grown and very bushy.

$\begin{array}{cccc}\text { NEW LOW PRICES } & 10 & 100 & 1000 \\ \text { 9-12 in. } 1 \text { yr. single branch, good roots, postpaid } & \$ 0.90 & \$ 7.50 & \$ 50.00 \\ 12-18 \text { in. } 2 \text { yr. very bushy. By express } & 2.25 & \mathbf{2 0 . 0 0} & \mathbf{1 7 5 . 0 0} \\ 18-24 \text { in. 3 yr. very bushy (fully developed). Express } & \mathbf{3 . 5 0} & \mathbf{3 0 . 0 0} & \mathbf{2 7 5 . 0 0} \\ 2 \text { to } 3 \text { ft. } 4 \text { yr. very bushy. By express } & \mathbf{5 . 0 0} & \mathbf{4 5 . 0 0} & \mathbf{4 0 0 . 0 0}\end{array}$

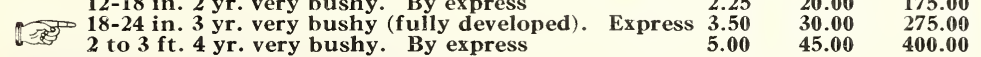

SPECIAL OFFER: We shall send you 12 carefully selected strong plants well branched and well rooted (12-18 inch size) for $\$ 2.50$ postpaid. They are so hardy they thrive anywhere.

A half-
dozen
Suggestions: $\quad\left\{\begin{array}{l}\text { Plant them in a row in front of your porch. } \\ \text { Plant them in opposite rows down each side of your walk. } \\ \text { Group them at the walk entrance. } \\ \text { Group them on both sides of your front steps. } \\ \text { Plant at the bases of shrubs and trees to hide unsightly bare spaces. } \\ \text { Plant them on the bare side of your house where other plants have failed. }\end{array}\right.$

Wherever you plant Collins Japan Barberry that spot will be brightened by rich green foliage all summer, brilliant gorgeous colors in autumn, clusters of sparkling red berries in winter, in short-beauty itself will there abide throughout the year. 


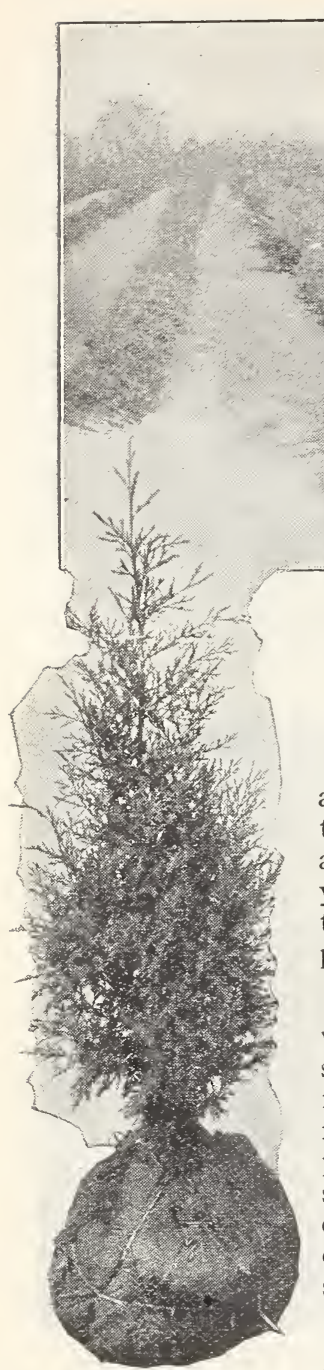

Big, thrifty roots on all Collins

Evergreens.

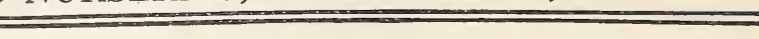

From the vast assortment and collection of Evergreens at our Nurseries you may come and make your own selection, and choose from the various colors, shapes, and sizes adaptable to any purpose. Only by seeing them with your own eyes can you learn to know them and appreciate them. We shall be very glad to assist you to make the proper selection for your needs and location.

However, if you are unable to come to the Nurseries, we shall be glad to call to "look over" your property, to study your needs, and to advise you what to plant. Or, if that is not possible, ask for our Bulletin No. 100, which makes it easy for you to show us the layout of your property. On your layout we indicate the plantings suggested-ideas based on the long practical experience of our Landscape Department. You are placed under no obligation, expressed or implied, by asking for these suggestions.

Our evergreens are systematically root-pruned, and owing to the fine quality of the garden loam in which they are grown they hold a large ball of earth when moved. vergreens. Beware of Evergreens that do not come with a good ball moved with most of the roots undisturbed in a large, solid ball of rich soil.

\section{FAMOUS PFITZER'S JUNIPER}

A fascinating grafted Evergreen with a most interesting habit of growth. Those who know it are its staunch admirers; we regard it as the most valuable and charming, in fact, the aristocrat of all the Evergreens today. Its color is difficult to describe, being a rich deep green, yet there are traces of blue and gray shadings, making it a dark handsome Evergreen. Its limbs grow upward and outward, with a graceful droop at the tips which softens its whole outline. Excellent in groups (give it space to develop) or as a superb specimen on the lawn, or at walk entrances.

Specimen Plants, measuring 2 to $3 \mathrm{ft}$. high, and 4 to $5 \mathrm{ft}$. across, developed perfectly, each $\$ 9.50 \mathbf{E}$; per matched pair $\$ 18.00 \mathrm{E}$.

E means by express (see page 67)

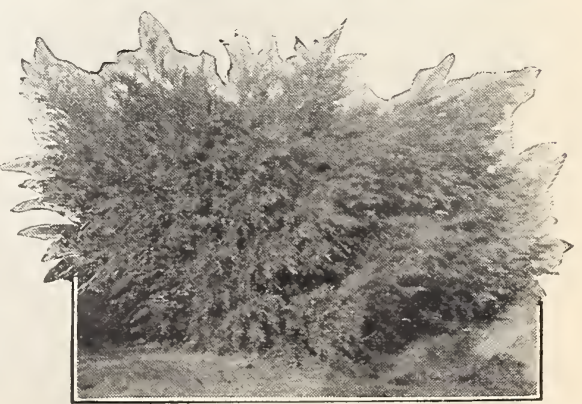

Pfitzer's Juniper 
BEFORE PLANTING

As the proper setting beautifies a jewel, so the proper foundation planting of evergreens beautifies the house. These two pictures-taken only three hours apart-show that you get immediate pleasing results if you plant Collins well grown, handsome evergreens.

\section{AFTER PLANTING}

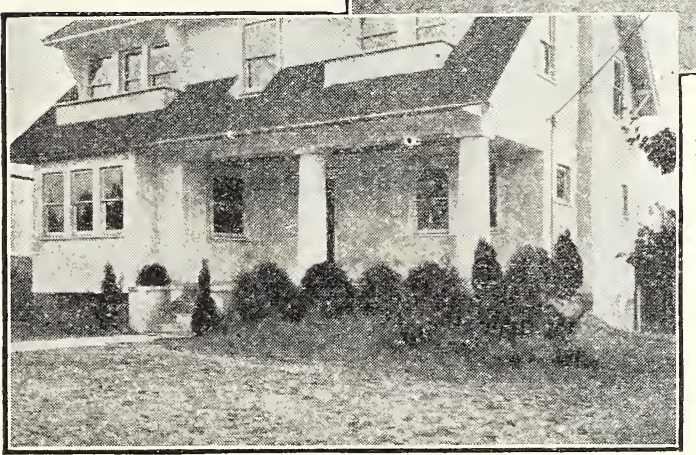

I have been admiring the shrubbery since the day you planted it. as everyone else has. Every tree seemed to start to vell as our neighe think, as heve nice a display, that whe in C- as nice a display as anyon

The special $\$ 24.75$ collection received in very good condition and I am very well pleased with it as the plants are larger than I had expected.

"My house looks bare, but I don't know what to do!"

How often we hear that! The words of the perplexed property owner who realizes his house is conspicuous but has neither the time nor the experience to "landscape" it wisely and correctly.

To help all of you who are in such a predicament we offer.

\section{"COLLINS LANDSCAPE COLLEGTION FOR 1926" (The Best Ever)}

containing six sheared Specimen Evergreens, five assorted Flowering Shrubs (for bloom in spring, summer and fall), four Japan Barberry plants which have brilliant fall coloring and red berries all winter, and two plants of the famous Viola Cornuta (Tufted Pansy or Horned Violet-producing a never-ending succession of rich royal purple blooms from spring until long after frost). The finest and most complete "Landscape Collection" we have ever offered.

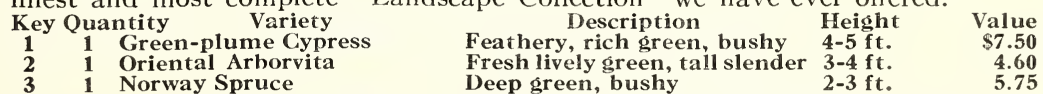

$\begin{array}{lll}2 & 1 & \text { Oriental Arborvita } \\ 3 & 1 & \text { Norway Spruce }\end{array}$

4) 2 Viola Cornuta

\section{Norway Spruce}

1 Norway Spruce

1 American Arborvita

4 Japanese Barberry

5 Assorted Flowering Shrubs.

succession of flowers.

Deep green, bushy

Royal purple flowers, spring

to frost every year

Deep green, bushy

Tall, slender, dark green

Green folliage, red berries

Forsythia, Se, red

-in, perennial 1.0 $2-3 \mathrm{ft}$. 5.75 2-3 ft. broad 4.25 $2-3 \mathrm{ft}$. 4.25 2.00

$3-4$ yr -5.00

$\overline{\$ 40.10}$

The cost to you $\quad\left(\begin{array}{l}\text { Packed, ready for } \\ \text { express shipment }\end{array}\right) \quad\left(\begin{array}{l}\text { Prepared only } \\ \text { when ordered }\end{array}\right)$

This is the only "landscape" collection we offer. We allow no substitution; by selling a great number of these collections we are able to offer you these first-class plants for $\$ 24.75$ to get you started. Here is your opportunity.

Every plant must suit you upon arrival or your money refunded.

In planting this collection about your house you add many times its cost to the value of your property immediately.

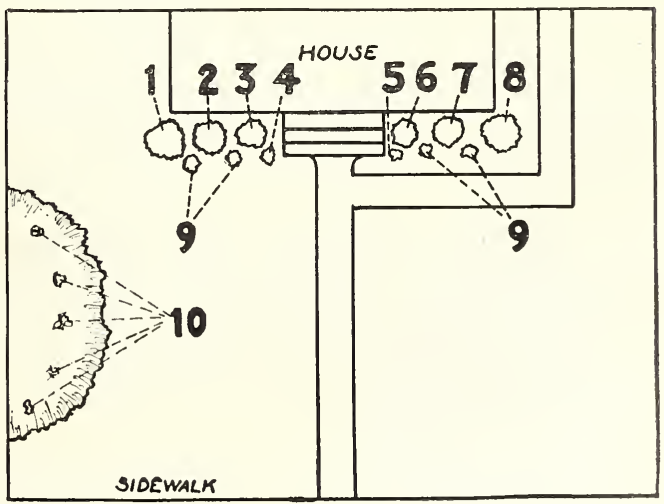




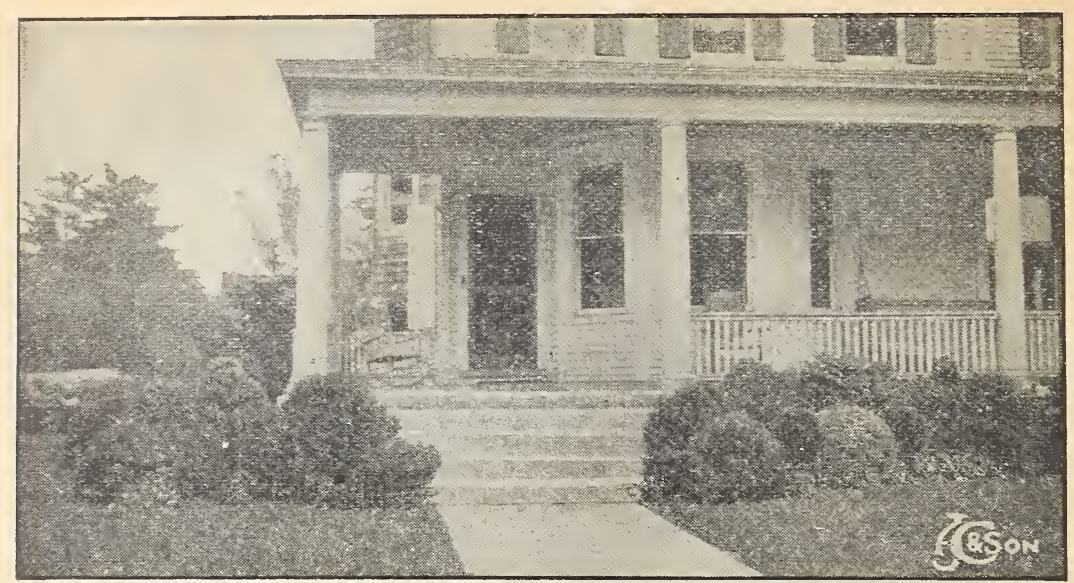

Proper selection makes these Evergreens part of a harmonious picture

\section{Collins Antique Boxwoods}

Richly fragrant Boxwood, slow-growing and thoroughly old-fashioned, gives the final needed touch wherever used. Excellent for window-boxes and urns in cities; or for neatly edging favorite garden paths, sun-dials or perennial beds. (Note the very low price in quantity.) Fine effect among flowering plants in window-boxes, remaining permanently green after flowers fade. Keeps the edges of flower beds from spreading.

Buxus suffruticosa. (Dwarf Boxwood.) This is the dwarfest form of all, growing extremely slowly and is the best-known of all varieties. Very pungent. Pleasing rich green.

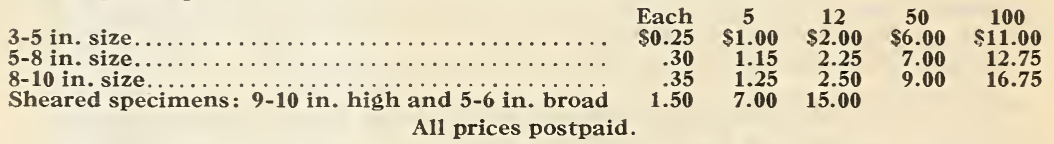

Buxus salicifolia. (Narrow Leaf Boxwood.) This is a fine ornamental variety having a narrower and darker green leaf than Buxus suffruticosa. Grows somewhat faster. Sweet odor. Very valuable for urns, and as specimen pyramidal plants. 12 inches $\$ 2.50$ each $E$; per pair $\$ 4.50 \mathrm{E}$.

\section{COLLINS GREEK JUNIPERS}

(Illustrated in colors in field scene at top of rear cover)

This beautiful evergreen is one of the very finest and most perfect varieties in our whole Nurseries. In outline this tree forms a symmetrical broad-based pyramid. Each year new layers of bright blue tips are added so neatly and regularly that trimming is never necessary. It is a silvery blue color, very formal and striking. One of the best for tubs or urns or on either side of the steps. Excellent for use with the " 6 Evergreens for $\$ 10$ " collection (see next page), in foundation and porch work. 24 inch, each $\$ 5.00 \mathrm{E}$; per pair, matched $\$ 9.50 \mathrm{E} ; 30 \mathrm{inch}$, each $\$ 6.00 \mathrm{E}$; per pair matched $\$ 11.50 \mathrm{E}$.

\section{AZALEA}

A. hinodigiri. (Fiery red.) Well-known favorites. These very attractive bushes, quite dwarf, burst into a fiery red mass of bloom in May-the color actually glows, and with evergreens as a background, the setting is perfect. Compact, bushy plants that always remain dwarf. 10 inches to 12 inches high, $\$ 3.00$ each $\mathbf{E}$.

I wish to thank you for the copy of your "Collins Planting Guide." It takes me well back to the seventies when I was a customer of the firm. As opportunity offers to use your Guide, it will be a pleasure indeed, as my experience assures me people can place an order with confidence in getting good stock true to name from you.-J. T. B., Baltimore, Md.

My friends have all greatly admired the boxwood in my window boxes and I have taken great pleasure in speaking well of your firm and its dealings.

Mrs. V. K. McC., Annapolis, Md.

P means by Parcel Post. Postpaid
E means by express (see page 67) 


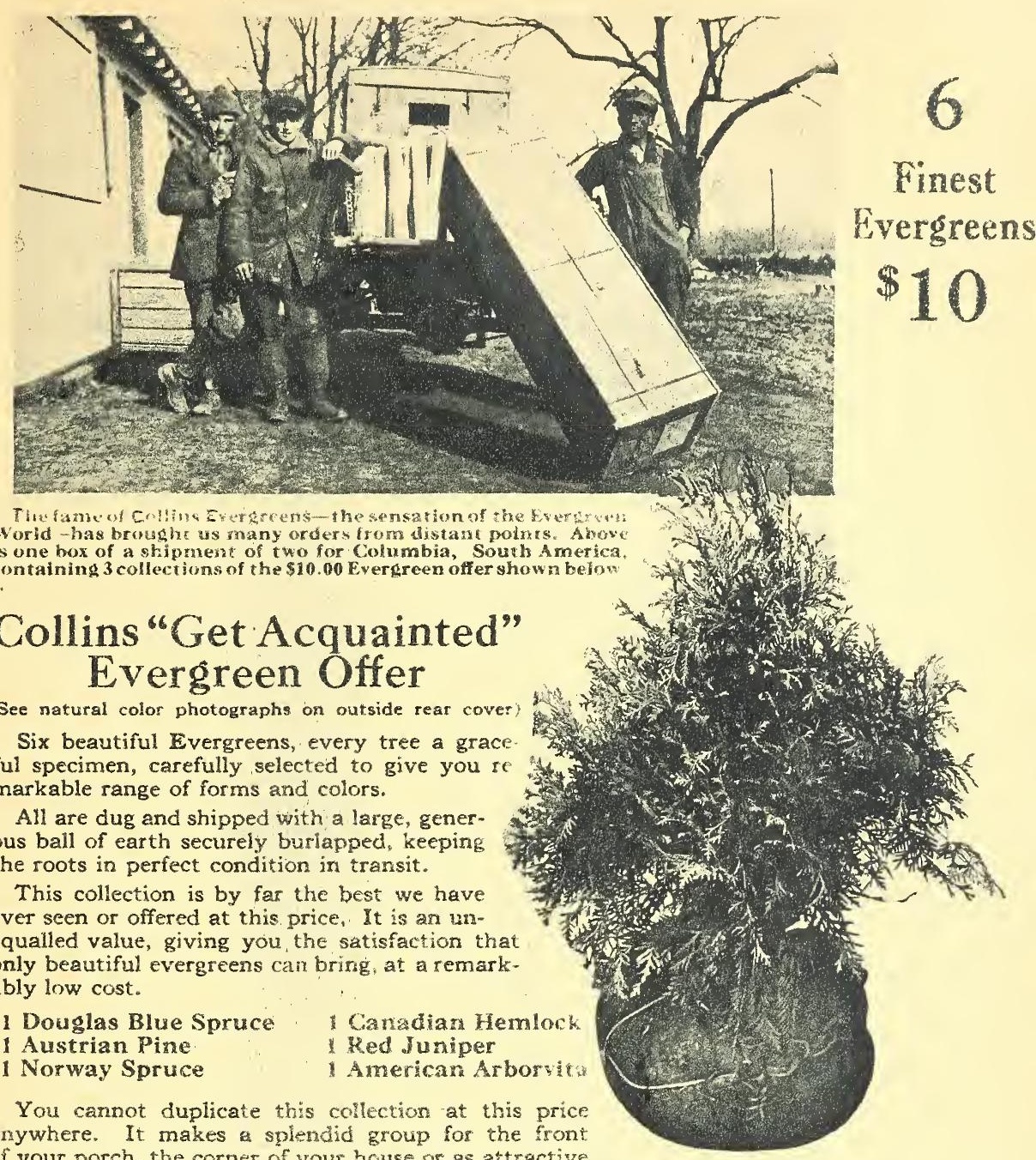
an your porch, the corner of your house or as attractive figures on your lawn; and the trees are equally charniing, planted singly or in groups. Shipments start in April and delivery to you is made as early as it is wise to plant in your locality.

\section{Ger this real walue}

\section{Charming Evergreens for $\$ 10.00$ by}

The six evergreens received and to say that I am delighted is putting it maldy. They certeinly look fine and healthy. Am enclosing check of $\$ 10.00$ for six more. My neighbors here ate very much interested and if this collection is as goot as the one thave already received, i can promise you at least severs more orders. J. MN. R., North Arlington, N. J.

The evergreens received in fine condition. I an pleased in every way with your salection, Nrs. K. K, T., Fairmont, W. Va.

Evergreens and shrubs received, and we are well pieased with vol selection, esmectally the pyergreens. which are beautiful.

The trees my husband ordered from you on fapril ist cam yesterday by express and are fine lowking trees.

Mrs. I. S. a Cordoya, Md

\section{Live Christmas Trees}

(For your Christinas Dinner Table).

Shapely, growing trees with roots istact and fu? of life. Their spicy, pleasant ochor fills the house Trimmed with Christmas decorations they mak an attractive, novel display. They can be set ou: as ornamental lawn trees after the holddays. $\$ 1.00$ each; or two for $\$ 1.75$, postpaid.

Each year we can furnish only a limited number and we suggest ordering now to avoid disappoint ment. Delivery before Christmas guaranted.

The two Christmas Trees came yesterday and they are littie beauties. Thanik you for them.

E. 6 . Eatirnore. M

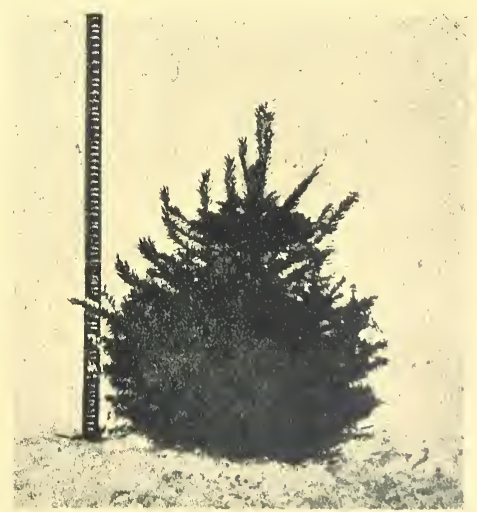





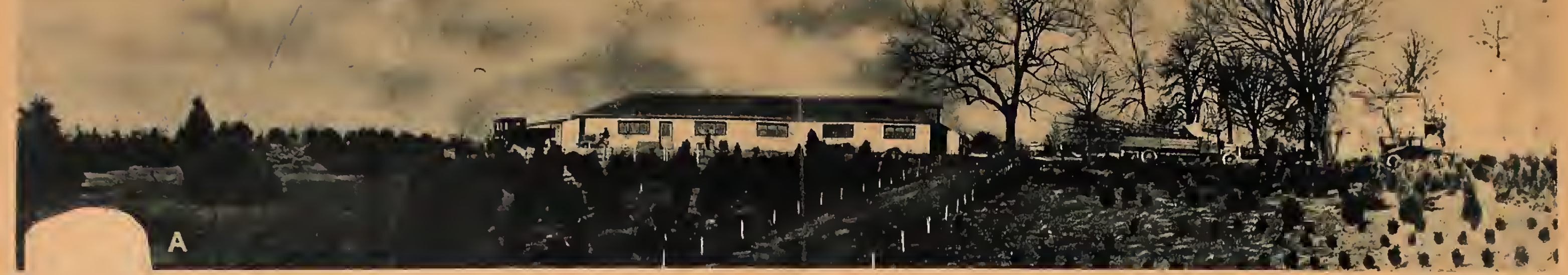

Towering 80 times as high as the Pyramids of Egypt 5 - ines as high as Upper Yosemite Falls

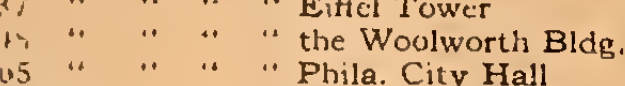
68 " " " " " "Washington Monumien 130 " " " " the Capitol, Washirigten 2 miles above Mt. Everest; nearly $2 \frac{1}{2}$ miles above Mt. McKinley would be the nonument made by placing the tubes icontaining last year's shipments of Collins Faultiess Five Roses on top of one another-each tube containing five livine rose bushes, side by side.

Placed end to end these tubes would reach $22^{\prime}$ times across the longest bridge span in the world - the central span of the new Delaware River Bridge:

$29,141 \mathrm{ft}$.

highert peak

in the world

MT. MCKINLEY longest steamship in the world.

A Single Day's Shipments Alake

$20,300 \mathrm{ft}$. highest peal in Ainerice

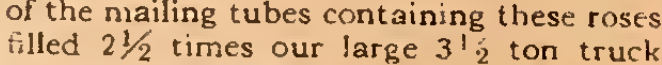
shown on this page (C).

Such a volume of business on one item alone in this catalog must mean sorne thing-must be the key to that which ho illustrations on this page.

Repeatedly people come to these Nurseries and tell of their satisfaction with goods previously purchased and buy lar additional amounts.

Over a hundred automobiles per day visit our nurseries in the busy seasun and carry away the finest of nursery products. The invitation is extended to all our friends and customers to see the nurseries for themselves.

UPPER YOSEMITE FALLS $1,436 \mathrm{ft}$. highear waterfallo in Americe PYRAMIDS OF EGYPT $46 I$ FT. HIGH

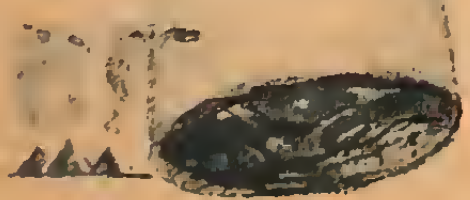

COLLINS NURSERIES Moorestown New Jerse A picturc of one of Collins Faultless Five Rose strong stem cut back to $2 \mathrm{ft}$. arising from a mass of sturdy.

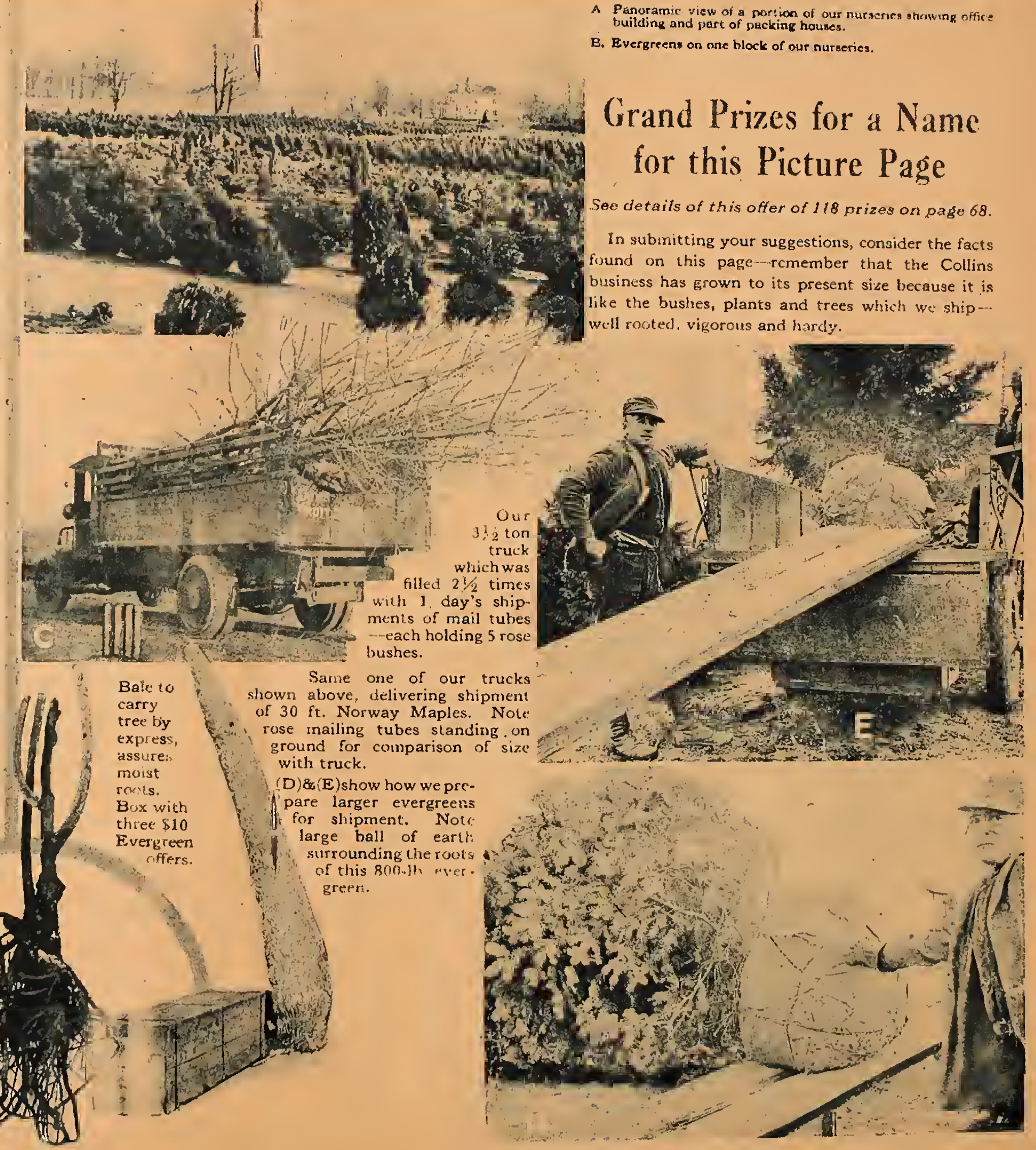

A Panoramic view of a nortion of our nur
building and pyart of packing houses.
B. Evergreens on one block of our nurberies.

Grand Prizes for a Name for this Picture Page

See details of this offer of 118 prizes on page 68 found on this page--rcmember that the Collins will rocted, vigorous and hardy. 


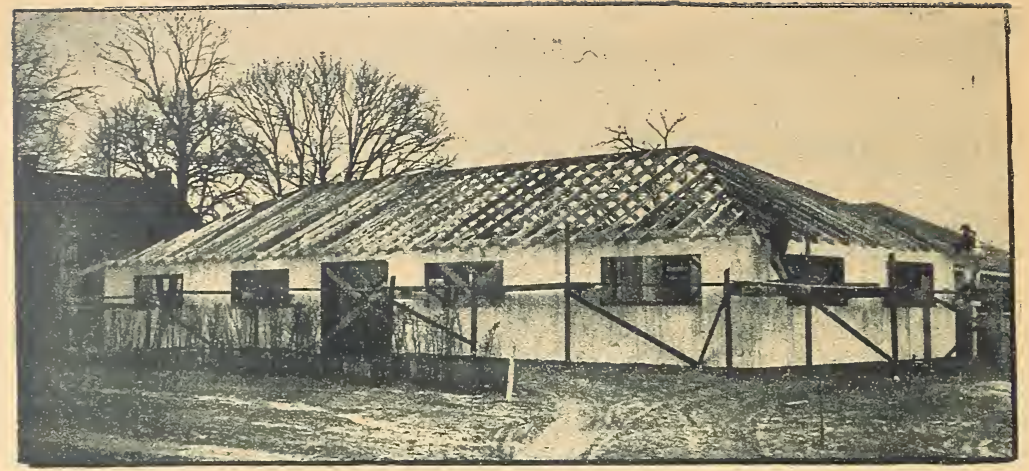

\section{Oux Constandy Increasing Sales of Rose Bushes}

founced on the satisfaction of purchasers have required that we keep constantly increasing the space devoted to that item in our line. The new packing house shown above in process of construction has been added since last season to take care of packing and shipping the increased number of orders, in order that you may be assured of prompt delivery when the proper planting time arrives.

In addition

\section{$61 / 2$ Acres of Land have been turned over}

to the growing of Roses only, as shown by the pictures below.

Since these pictures were taken we have had the most modern overhead irrigation system installed on this fertile land, thus assuring you the same sturdy bushes with the strong healthy roots we have always sent you.

It certainly gives me great pleasure to inform you how lovely your rosed have grown which I bought from you in the month of May. All five are blooming and everybody is astonished to see how large the flowers are. I shall want about fifteen more bushes in the spring just as early the ground is fit.

Mrs. E. R. T., Hanover, $\mathrm{Pa}$.

5 got the five roses from you in the spring and they have given us stsch satisfaction, that I am sending you this order. The five roses have bloomed all summer and are full of buds now.

$$
\text { Mrs. A. M. F., Arlington, Va. }
$$

Sometime in the early part of last summer I ordered your "Faultess Five" Collection of roses which grew and bloomed far beyond my expectations. We had roses until nearly Christmas. My Golden Ophelis did the best of all. I counted thirty-nine roses and buds on it at one time. My White Killarney did elmost as well. It had some of the most perfect roses on it that I have ever seen.

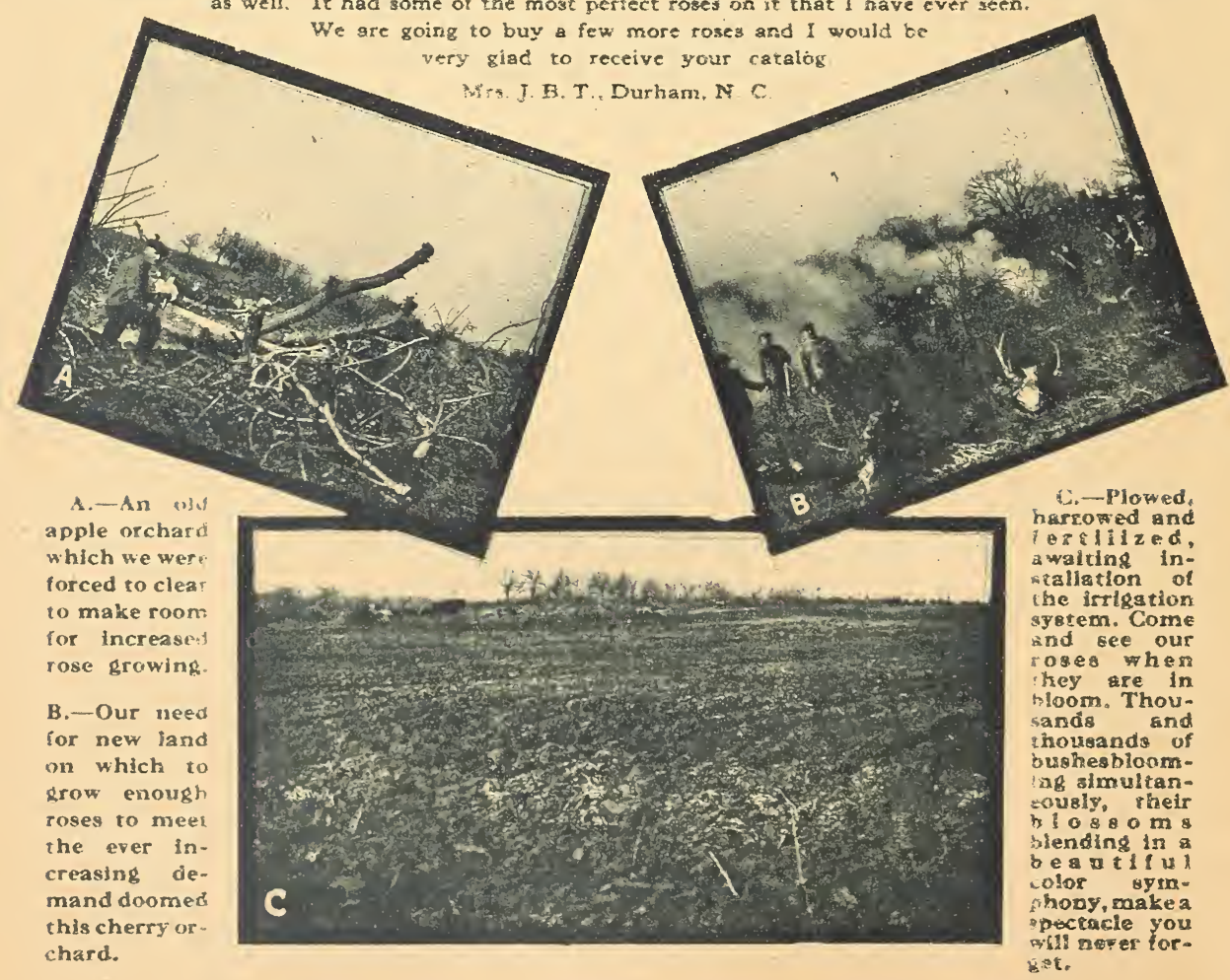




\section{Read What Collins Roses}

The following comments are unsolicited and refer in all cases to our \$1.95 Faultless Five Rose Collection.

\section{BLOOM DESPITE SNOW}

For several years we have bought no other rose bushes except Collins Faultless Five; for which you had several

orders from us. The bushes are all strong, the flowers fine, but never before have I seen so pretty a sight as the White Killarney bloom when it was two-thirds open with the ground all around covered deep with snow. We brought it in, photo Germantown, Philadelphia.

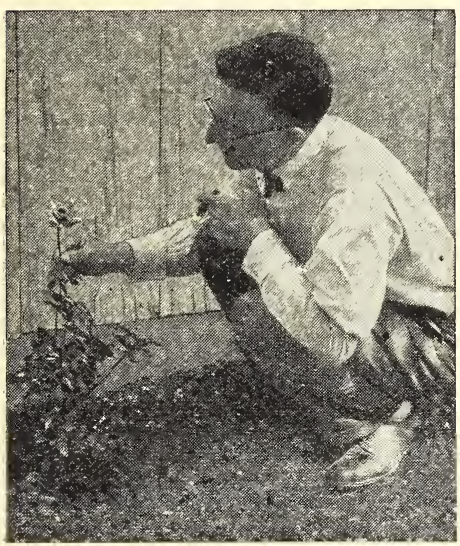

\section{1\%2 INCH ROSES, 44 DAYS FROM}

\section{PLANTING}

Your Faultless Five received June 3rd and all are doing nicely. In exactly 30 days we had the first bud, and 14 days later a wonderful flower on the Columbia, measuring $4 \frac{1}{2}$ inches across.L. P. M., York, Pa.

\section{THREE YEARS' SUCGESS IN GITY}

Your special rose collection bought three years ago has proven very satisfactory in my small garden; blooming entire summer and late in fall. Results better than the highest priced bushes I ever bought.-B. F. R., Philadelphia.

\section{“TRUE TO NAME," SAYS VERMONT GUSTOMER}

Your "Faultless Five" has proven true to name. Despite last winter's cold, every one has lived and produced wonderful flowers this year.

PICKED THREE ROSES NOVEMBER 14th

I have a wonderful rose bed, the bushes came from you. This morning (November 14th), I had the pleasure of picking three beautiful roses from it.-W. J. A., Ridgewood, N. J.

\section{WINS TWO BLUE RIBBONS AND SECOND PRIZE}

With blooms from bushes in your $\$ 1.95$ Rose Collection my sister won two blue ribbons and a second prize in the large Peoria Flower Show, in which she had much competition. I have seen your roses in other gardens to which I have sent them and the owners are all delighted-H. P. E. New York City.

\section{ROSES OR BUDS EVERY DAY}

I am writing to tell you about the roses I received from you last year, also the ones this year-they are wonderful, and every day I have roses or buds from them. I am sending you the name of a friend who is interested also.-Mrs. J. R. G., Liberty, N. Y.

\section{MAINE BUYER WANTS 90 MORE BUSHES}

My roses are wonderful-I am wild about them. Next year I will buy about 90 more roses from you as I want a real rose garden.-Mrs. W. S. K., Bath, Maine.

\section{MINNESOTA REPORTS BEAUTIFUL BLOOMS}

Of the Faultless Five bushes the Golden Ophelia has had five beautiful roses (as shown by picture). We thought them the most perfect roses we had ever seen
until the American Legion gave us a rose which surpasses anything we have yet had in color and fragrance.C. H. R., Staples, Minn.

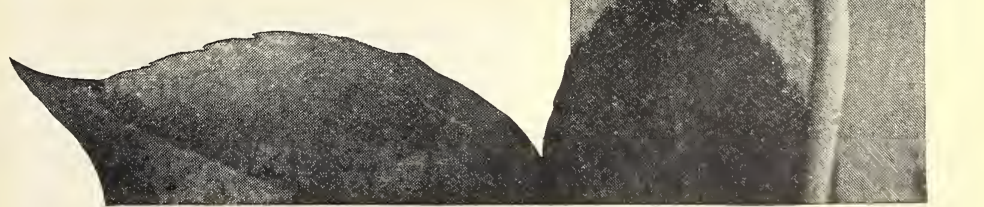




\section{COLLINS DECIDUOUS TREES}

are beauties. Their trunks are straight, they are well branched on every side and, what counts most, they have plenty of good fibrous roots. Buy a tree that has good roots; it always saves trouble later.

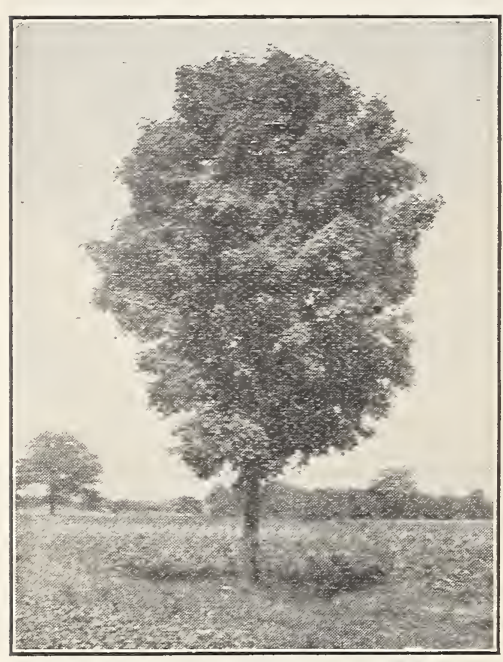

Sugar Maple - a beautiful shade tree for the lawn or street

\section{Acer . The Maple}

A. platanoides. Norway Maple. A large and handsome tree with a compact round head. Leaves bright green, paler beneath, smooth on both surfaces, changing in Fall to beautiful tones of yellow and gold. A splendid street tree; equally desirable for lawn or landscape. 8 to $10 \mathrm{ft}$., $\$ 3.50 ; 10$ to $11 \mathrm{ft}$., $\$ 4.25$ 11 to $12 \mathrm{ft}$., $\$ 5.00$.

A. saccharinum. Sugar Maple. Large, stately, dense tree. Leaves dark green above, pale below, turning in autumn to brilliant shades of scarlet, orange, and yellow. A quick grower, adaptable toall soils. (Noteillustration.) 8 to $10 \mathrm{ft}$., $\$ 3.00 ; 10$ to $12 \mathrm{ft}$., $\$ 3.75$.

\section{Betula . The Birch}

B. alba. European White Birch. A handsome and very ornamental tree with white and papery bark. Set out a group in front of white pines or hemlocks and you will have a charming winter background. 6 to $8 \mathrm{ft}$., $\$ 2.75$.

\section{Catalpa Bungei}

\section{The Umbrella Tree}

A dense, round-headed bush, grafted high on a straight, upright stem. Very hardy and effective; much used in formal gardens and lawns, having the outlines of the standard bay tree. 5 to $6 \mathrm{ft}$., medium heads, $\$ 2.50 ; 1 \frac{1}{2}$ inch stems, large heads, $\$ 3.00$.

\section{Crataegus}

\section{The Hawthorn}

Crataegus oxy. alboplena. English Hawthorn. Has clusters of double white flowers, resembling little roses, during May and June. A small tree to 15 feet; fruit scarlet. 2 to $3 \mathrm{ft}$., $\$ 2.00$.

\section{Cornus . The Dogwood}

C. florida. White Dogwood. One of the most beautiful flowering trees; leaves bright green, turning red or scarlet in the fall. The flowers, borne in spring, are white, very showy, and abundant. Fruit in the fall is bright scarlet. Very satisfactory. 3 to $4 \mathrm{ft}$., $\$ 1.50 ; 4$ to $5 \mathrm{ft}$., $\$ 2.00 ; 5$ to $6 \mathrm{ft}$., extra developed, \$2.75.

C. florida rubra. Red Dogwood. Strikingly beautiful, in contrast to the white-flowering forms. Conspicuous flowers of bright rosy red or pink. Autumnal tints of foliage are brilliant. $21 / 2$ to $3 \mathrm{ft}$., $\$ 3.75$.

\section{Cydonia Japonica}

Japan Flowering Quince

This is a very attractive bush. Quite popular since it is such a prolific bloomer in May of beautiful orange-red flowers which cover the plant and make it appear as a blaze of color. The quince-shaped, fragrant fruit of golden yellow remains a long time in the summer. Very attractive and dwarf in habit. $11 / 2$ to $2 \mathrm{ft}$., $\$ 1.00$ each; 2 to $3 \mathrm{ft}$., $\$ 1.75$.

\section{Gingko Biloba}

The Maidenhair Tree

Also called Gingko. This makes a small tree, very slender and neatgrowing. It is proof against diseases and insects. The Gingko is the only tree known that has no midrib in the leaf, which is similar to that of the maidenhair fern. The bark is clean, the trunk straight; a dainty, artistic tree, always interesting. 8 to $10 \mathrm{ft}$., $\$ 2.75$.

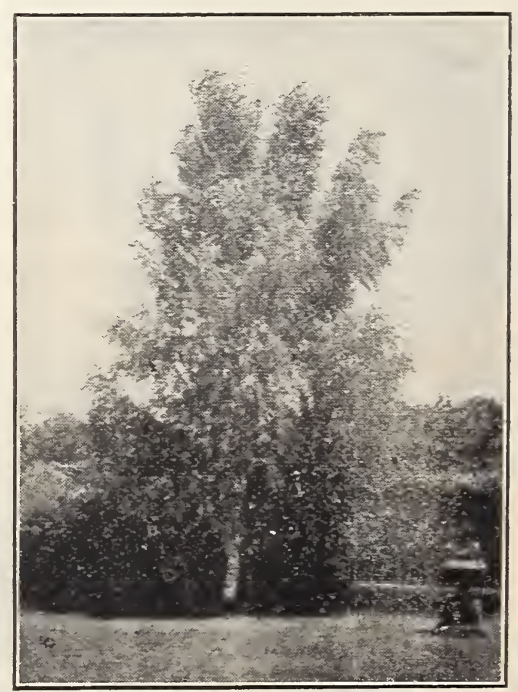

Graceful White Birch 


\section{DECIDUOUS TREES} Continued

\section{Quercus . The Oak}

Q. coccinea. Scarlet Oak. Turns a fiery scarlet in the fall, making it very desirable for lawn or street planting. 6 to $8 \mathrm{ft}$., $\$ 3.50$.

Q. palustris. Pin Oak. The handsome, drooping branches form a broad, shapely, pyramidal crown; pleasing bright green foliage, deeply lobed and sharp pointed, turning to gorgeous reds and browns in autumn. 8 to $10 \mathrm{ft}$., $\$ 3.75$.

\section{Tilia . The Linden}

Tilia europaea. European Linden. A fine vigorous grower, forming a compact symmetrical tree, handsome and stately. Quantities of fragrant flowers are borne in June. Good green foliage. Fine for street planting, also for lawns. 10 to $12 \mathrm{ft}$., $\$ 4.25$.

\section{Ulmus . The Elm}

Ulmus americana. A magnificent native tree, with a wide-arching top and out-curving branches. The green foliage turns yellow in the fall. Stately and handsome, they are well-known through New England. 8 to $10 \mathrm{ft}$., $\$ 2.50$.

\section{Malus}

Flowering Crab Apple

Malus ioensis. Bechtel's Doubleflowering Crab. A fine new doubleflowering variety. Flowers have a delicate blush-coloring or shell-pink, and are highly scented. 3 to $4 \mathrm{ft}$., $\$ 2.25$.

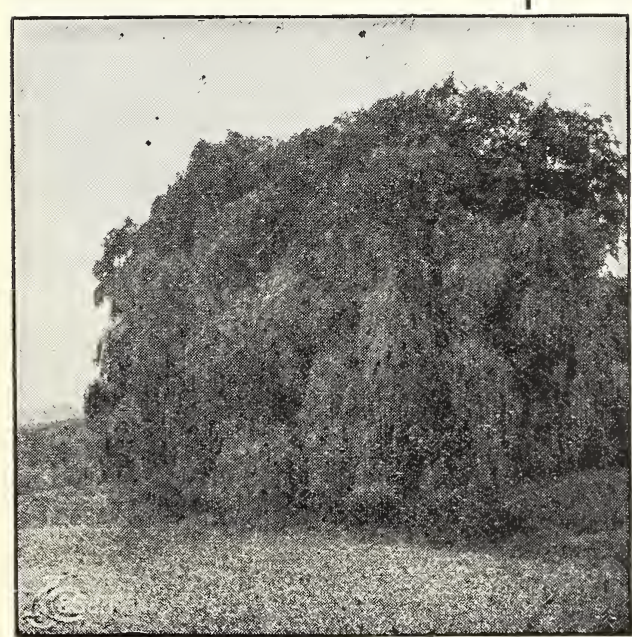

Weeping Willows
Weeping Mulberry Tree

\section{Morus alba pendula}

The Weeping Mulberry

A beautiful weeping, drooping tree; hardy, thrifty and most ornamental. The branches are extremely long and slender; the foliage is light green and the fruit reddish purple. (See the illustration.) Medium heads, \$2.75, large heads, $\$ 3.75$.

\section{Platanus orientalis}

The Buttonwood

Oriental Plane. One of the most massive and rugged of American trees. On account of the patched and mottled appearance of the bark, the trunk and branches are very attractive through winter. Not affected by smoke of cities nor worms and insects. 8 to 10 ft., $\$ 2.50$.

\section{Populus . The Poplar}

Lombardy Poplar. A tall, columnar tree of picturesque and very formal aspect. Valuable for avenue planting, for windbreaks and screens as well as for the lawn. The tall tops, reaching above the surrounding trees, are very striking. 6 to $8 \mathrm{ft}$., $\$ 1.50$. 8 to $10 \mathrm{ft}$., $\$ 2.00 ; 10$ to $12 \mathrm{ft}$., $\$ 2.50$.

\section{Salix . The Willow}

Salix babylonica. Weeping Willow. A large tree with slender branches. The narrow leaves, tapering to a long point, are bright green and the first to appear in spring. Very picturesque; universally known. Fascinating in a high wind. (The illustration at left shows a group of four.) 6 to $8 \mathrm{ft}$., $\$ 2.50 ; 8$ to $10 \mathrm{ft}$., $\$ 3.00$. 


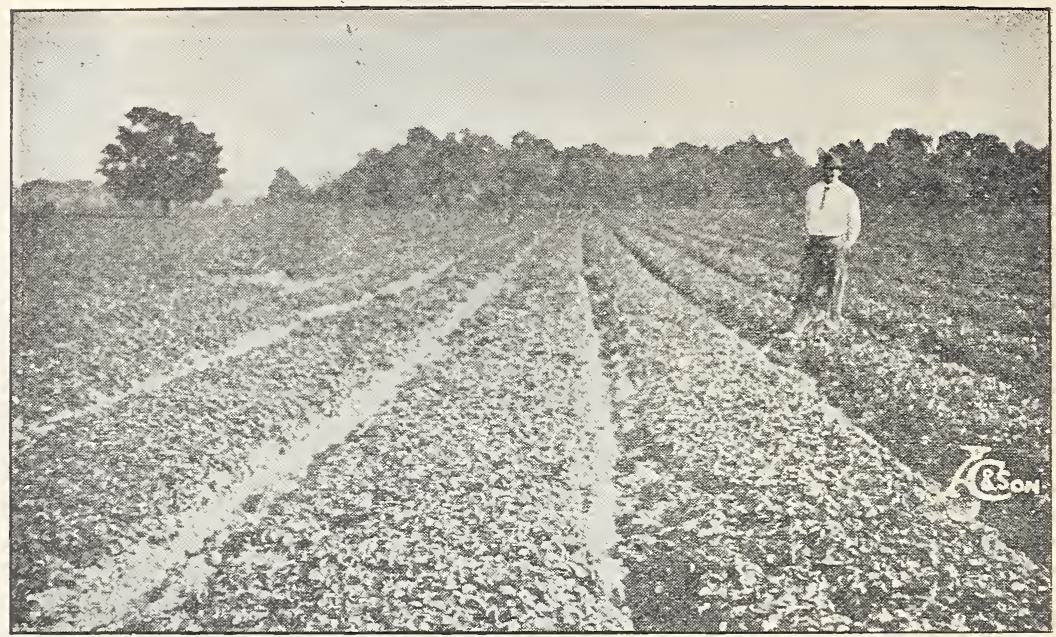

Beds like these furnish us thousands of clean, thrif ty plants

\section{Collins Selected Strawberry Plants}

The above photograph shows our digging beds-where the plants you buy will come from 600,000 plants in this block alone. We spare no pains to produce the best plants. The ground is heavily manured and deeply plowed before setting out our young plants in the spring. They soon take root, and grow rapidly, forming new runner plants early in the season. We hoe these beds frequently to keep the weeds back, in order to give the plants every show. As a result we have a block of sturdy young plants by fallhealthy, vigorous and very well rooted. Therefore when you plant them in your garden or your field you will get results.

Shipments. Our Plants are Healthy Field-grown Plants. Our shipping season is in the spring months, also from September 15 th to November 1 st. However, we advise planting Strawberry Plants in the Spring. The Everbearing varieties will bear that Fall and the standard varieties the following

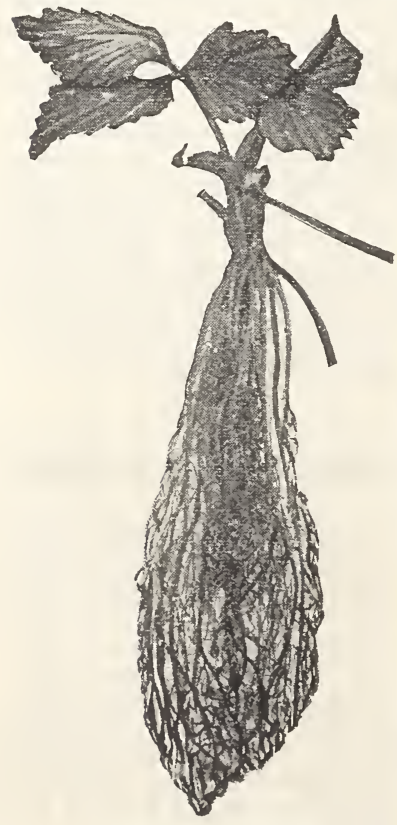

A Collins well-rooted Strawberry Plant year. We can furnish potted plants from July 15 th through the summer, these are moved with a ball of earth and produce berries the following year, prices furnished upon application. Upon receipt of your order your Strawberry Plants will be dug, then packed in damp moss and mailed or shipped to you immediately. When they arrive plant them promptly, or keep them in a cool place. Never allow the roots to become dry, and you should not lose a plant.

(Varieties listed and described on the next two pages.)

Gentlemen: Strawberry plants received and they are the finest rooted plants I have ever received.

$$
\text { S. B., Birmingham, Ala. }
$$

Gentlemen: The strawberries I purchased from you in the Spring of 1919, did wonderfully well. These plants have grown 18 inches tall and altho I planted them 18 inches apart they are crowded for room, they spread out so far.

My father bought strawberries and other plants from your firm 50 to 60 years ago. This I remember when I was a boy.-T. S., Wilmington, Del.

I purchased some Lupton Strawberry plants last year and although they were set out late and the season one of the driest, they did well, covering the entire space between the rows.-E. G. H., Hasbrouck Heights, N. J. 
AROMA. Per. Midseason. One of the leading fancy-marked berries. Vigorous grower and very productive. Large. Red in color and of fine quality, with a handsome bright green cap. Very firm and will carry to market in excellent condition.

BIG JOE. Per. Midseason. Big Joe is one of the highest-priced and most popular berries in the New York markets. Plant a strong grower, makes lots of plants and a good fruiting bed. Berries handsome, firm. and of good quality.

COLLINS. Per. Midseason. This fine berry fruits abundantly on any soil. The berries are rich dark red, firm and sweet, making them ideal for canning; heavily planted in all canning sections of the country.

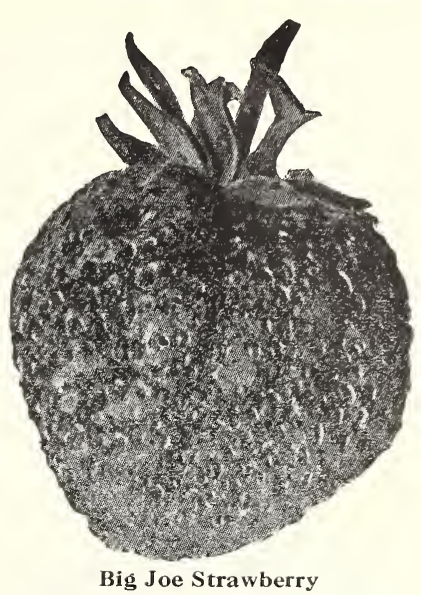

DR. BURRILL. Per. Midseason. This variety should be in every home garden. The dark red berries are particularly attractive and the color penetrates to the center. The berries are moderately firm and very productive, with a beautiful green calyx.

EARLY JERSEY GIANT. Per. Early. Yield very large berries very early in the season. Ripen all over at once; flavor rich and mild, berries very showy.

FORD. Per. Late. Ripens about ten days later than the Premier, has practically the same quality and is suitable for all soils and climates. One of the very best in eating quality and presents a fine appearance and is firm and highly productive. We offer the genuine FORD Variety.

GANDY. Per. Late. Berries large and firm, highly colored and uniform. Plant strong grower; produces big crops.

GLEN MARY. Per. Midseason. Dark red berries; good shippers, firm; excellent flavor; quite fancy. Plants are extra-strong growers, known to produce 10,000 quarts to the acre.

KLONDYKE. Per. Early. Very largely planted and one of the most profitable berries grown. Fruit medium in size, dark red and is firm and of very good quality. Excellent for the home garden.

LUPTON. Per. Late. The finest berry in the whole list. Quality good;

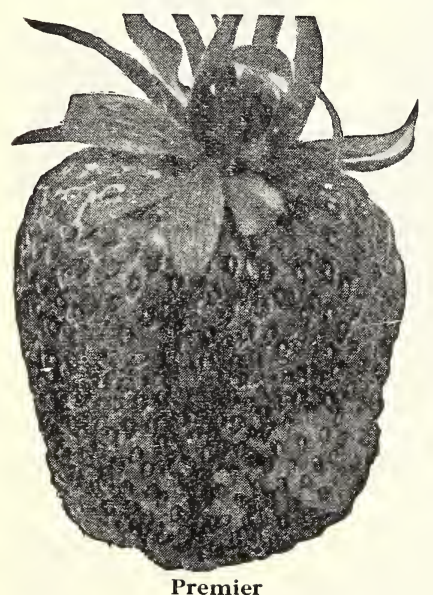

Premier fruit very large, will stand much shipping. Plants strongest growers; foliage heavy and abundant. Most satisfactory. Being very solid it holds together and does not go to pieces when cooked.

PREMIER. (Howard No. 17.) Per. Very early. This comes very near to being the perfect strawberry in the opinion of many strawberry growers. Grows on rich land or poor, light or heavy, wet or dry and outclasses all other early berries. Premier is enormously productive; berries are uniform in shape. The rich red color extends clear through the berry. The bright green cap heightens the color of a box of these berries. Delicious in qualityequal to the very best. The berries are firm, fancy, and will make money for all who grow them. We cannot endorse PREMIER too strongly - it should be in every home garden.

SENATOR DUNLAP. Per. Second-early. Plants grow like weeds, are very productive, and have extra-long flowering season. Fruit bright red, glossy, and very attractive.

WM. BELT. Per. Midseason. Berries have excellent flavor, are quite firm and very fancy. Plants very productive, rugged and stand drought well, a very satisfactory kind for either garden or market.

Prices of above Strawberry Plants. 25 plants 85 cts.; 50 plants $\$ 1.35$; 100 plants $\$ 2.10 ; 250$ plants $\$ 2.90 ; 500$ plants $\$ 4.75$. Prices on larger quantities on application.

Quickest and best deliveries are made by Parcel Post, right to your door, therefore all above Strawberry Plants will be mailed for the prices above specified, up to and including 4 th postal zone. 


\section{COLLINS NEWEST BERRIES}

St. Martin. Enormous size, many specimens measuring 6 inches and over in circumference, averaging about 30 to the well-filled quart basket. Excels in productivity and size. Berry deep red, no knotty tips. Flavor excellent. Plants make many rigorous runners, and a few plants set out will soon make a thickly matted row. Long after the other berries have dwindled in size and stopped bearing, the St. Nartin is still ripening up big luscious berries. Every berry matures fully whether it is the first or the last picking of the season. It is a sheer joy to pick such a berry. Price same as "Bushel Basket." (See below.)

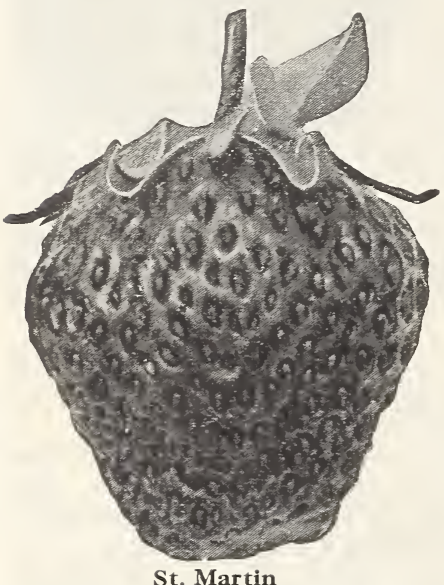

St. Martin

\section{Bushel Basket Strawberry}

This is something very new and startling in the Strawberry line. One plant has been known to produce 508 plants in a summer, of course the plant was fed strong plant food. Some Bushel Basket Strawberry plants grow so large that a bushel basket will not cover them. The berry is of sprightly flavor and of a beautiful shade of red. It is slightly necked, making picking easy, is extra large, and is a good canner being red to the core. It is not hollow at the core nor tough, and has small seeds. It is a money-maker. This berry has won the Barry Gold Medal.

Price of St. Martin and Bushel Basket. 12 plants 90 cts.; 25 plants $\$ 1.50 ; 50$ plants $\$ 2.50$, postpaid; by express, 100 plants $\$ 3.75 ; 250$ plants $\$ 7.50$. Prices for larger quantities on request.

\section{Collins Everbearing Strawberries}

Progressive is a persistent bearer, producing from the time other plants begin to bear in the spring until a very heavy frost in fall. This variety makes strong, vigorous plants, and it is a home-garden berry as well as a market variety, the berries being of high quality, firm, delicious, and very productive. 25 plants $\$ 1.00,50$ plants $\$ 1.75$

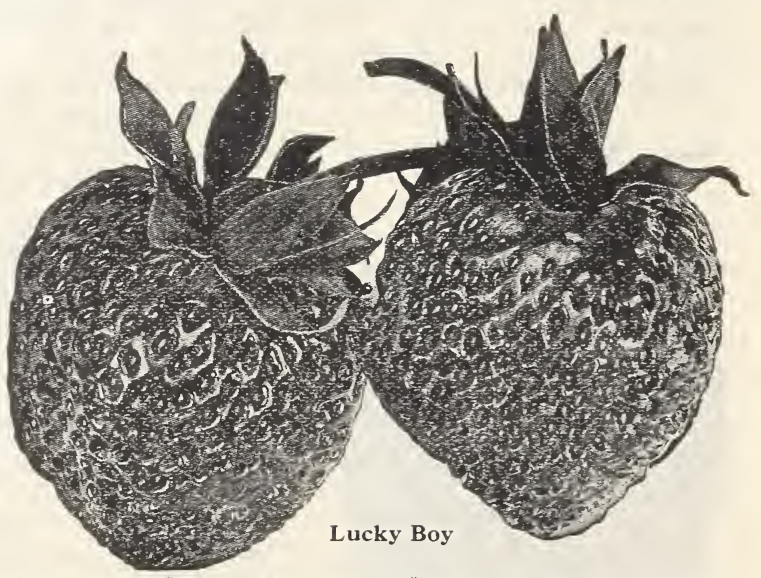
postpaid. By express, 100 plants $\$ 2.50,250$ plants $\$ 4.50$. Prices for larger quantities furnished on application.

LUGKY BOY is the biggest, sweetest, most productive berry. It makes runners and new plants fast and, being deeply rooted, is quite droughtresistant. Young runner plants will fruit in a few weeks after rooting, and will produce a good crop if blossoms are kept cut until July, when they may be allowed to bear. This is the best quality Strawberry we know of. It is larger than either Progressive or Superb and is produced in immense crops. We believe it will produce 20,000 quarts to the acre if given good culture. 25 plants $\$ 1.50$, 50 plants $\$ 2.50$, postpaid. By express, 100 plants $\$ 3.75,250$ plants $\$ 7.50$. Prices for larger quantities on request.

Gentlemen: The catalog I had, gave to son who ordered from you Oct. 13. I have picked strawberries from everbearing plants which you sent, they are a wonderful plant.-J. M. C., Phila.

Dear Sir: Will you send me twenty-five Progressive Strawberry plants by Parcel Post as I got some last year and they were fine.-G. R., Stamford, Conn. 


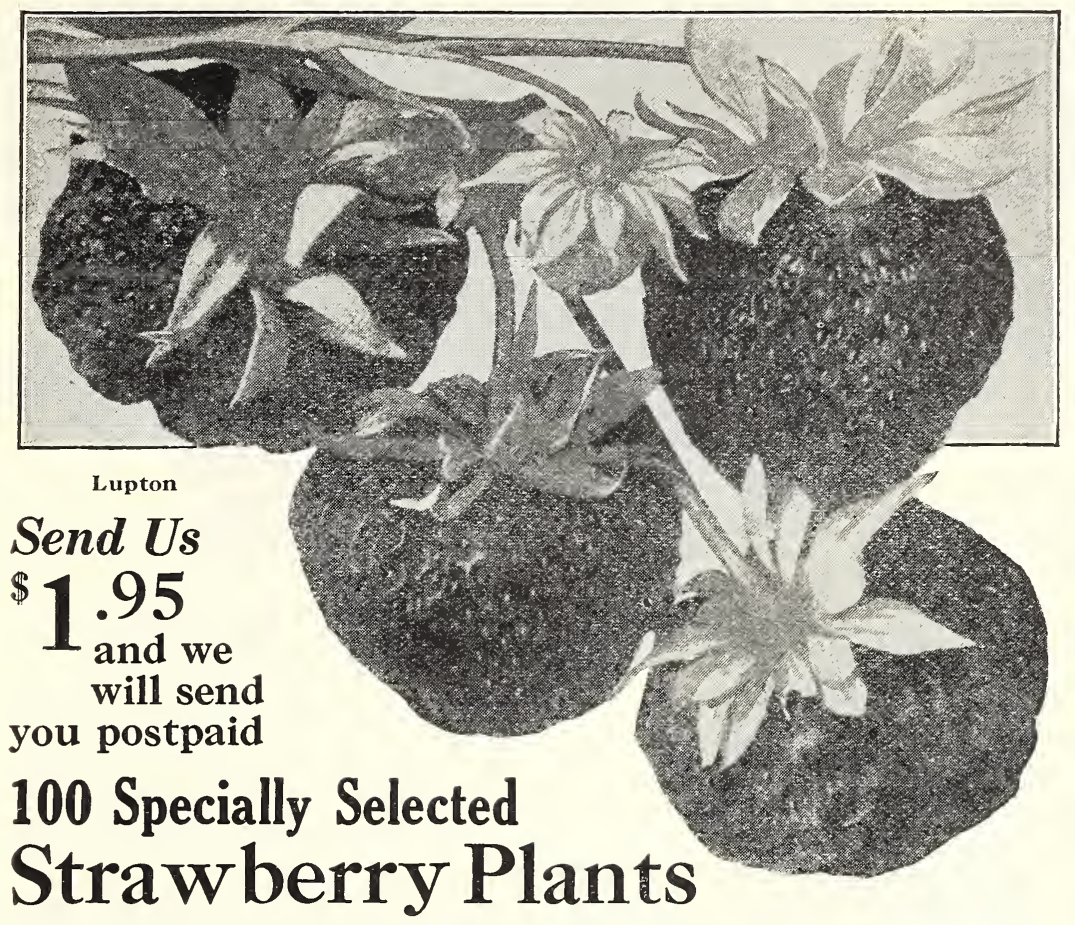

your choice of 25 plants each of any four varieties from the following six finest, big crop varieties:

Progressive. Bears all
summer summer until frost.

Glen Mary. Midseason; fancy productive.

Premier. Nearly the perfect strawberry. Delicious, firm and fancy.

Big Joe. One of the best for home garden.

Wm. Belt. Late; richflavored.

Lupton. Fine for canning; solid; large.

These plants are separately selected, each one a first-grade plant, and the best your money can buy. us to grow. Any that die will be replaced free.

Dear Sir: The parcel post collection of the "four varieties of berries" came duly to hand and in splendid condition. They are fine H. D., Greenwich, Conn.

From the thousands of these collections, formerly sold at $\$ 3$ each, we have many other enthusiastic letters.

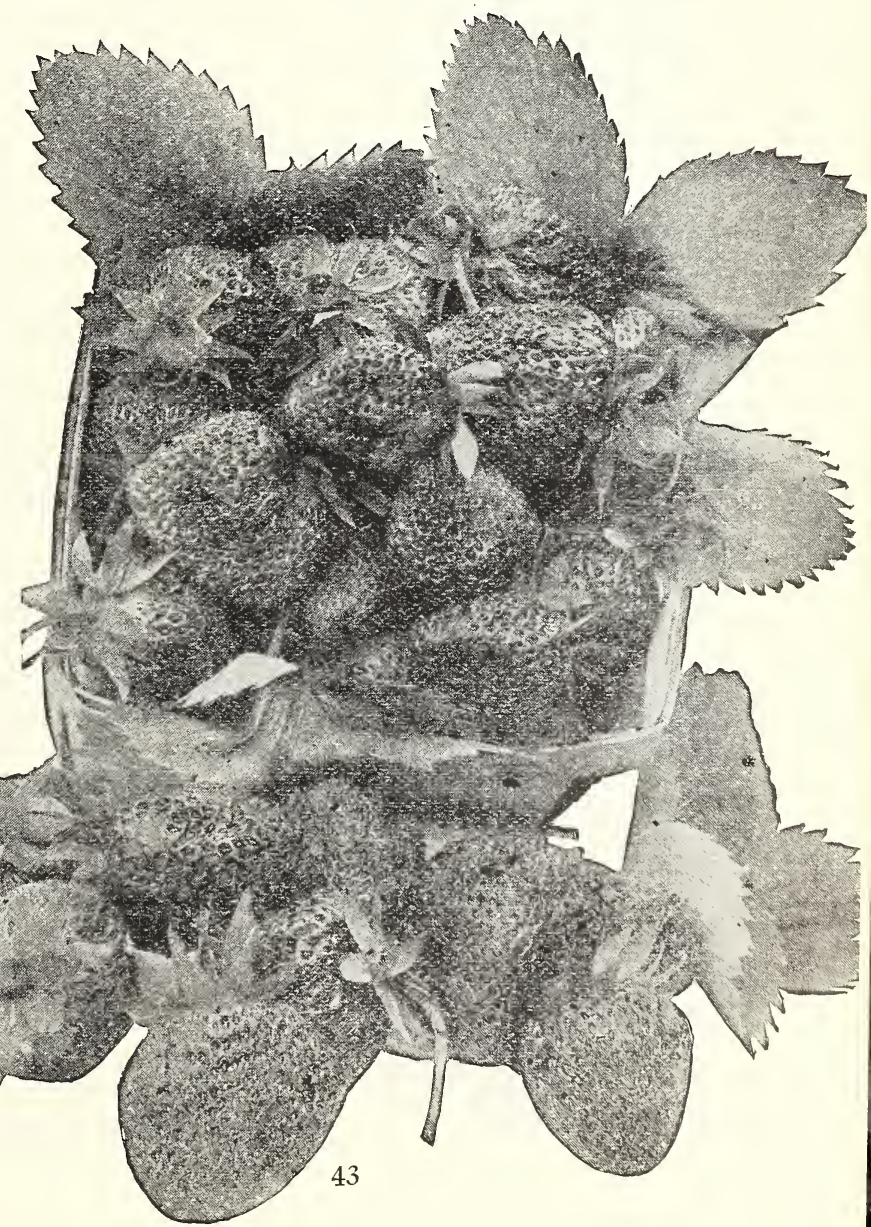


COLLINS NURSERIES, MOORESTOWN, N. J.

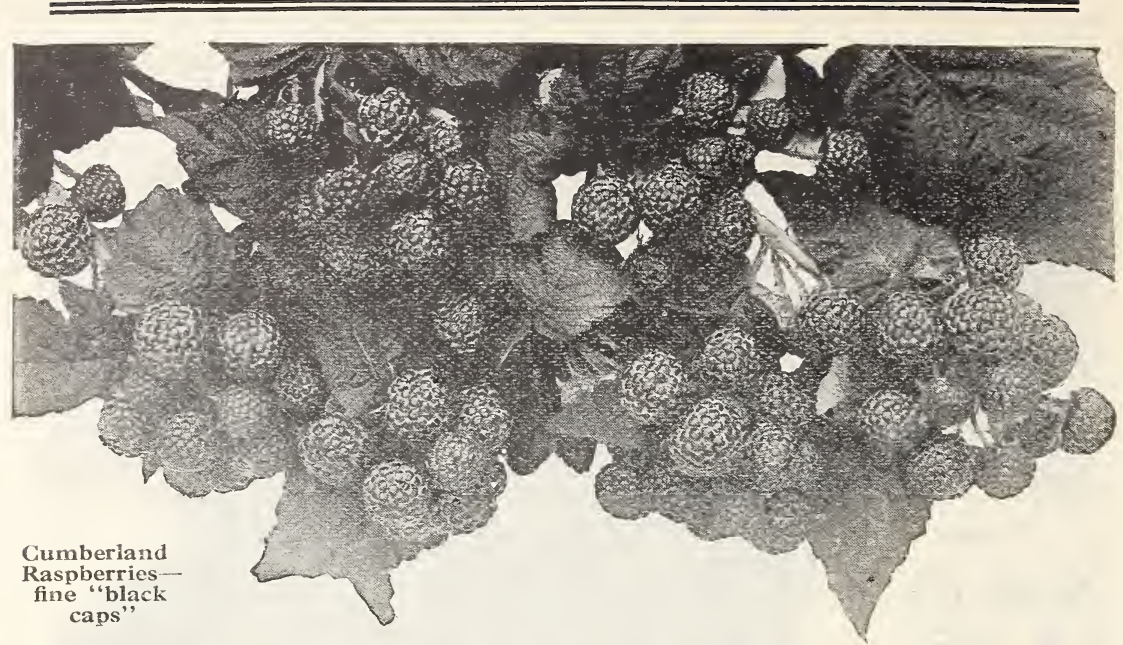

\section{COLLINS RASPBERRIES}

Among the berries we consider the Raspberry to be second only in importance to the strawberry. It is strong and hardy, requiring little care, and is less affected by the drought than strawberries. Every garden should have Raspberries, and any soil that is capable of raising vegetables will raise good Raspberries. Yield is about two quarts per bush per year.

For commercial planting we recommend King, Cuthbert, Marlboro, and St. Regis, which varieties bear in the order named. Cumberland, Gregg, and Plum Farmer, we recommend as good blacks. Plant the bushes 2 feet apart in the row and 5 feet between rows, about 4350 to the acre.

In the garden they may be planted closer together, that is, 2 feet apart, and the rows 4 feet apart. Thus, in a garden plot that contains 300 square feet, you can plant 36 bushes and these will give you about 70 quarts per year. Tre suggest King, Cumberland, and St. Regis. This gives a good early red, a black, and an everbearing which makes a nice succession.

Cardinal. Purple. Vigorous in growth, hardy, and productive. The berries are of medium quality. 75 cts. for $10 ; \$ 5.50$ per 100 .

Columbian. Cap. Purple. Has a rich juicy pulp and a good flavor. It is of remarkable vigor and productiveness. The berry is somewhat conical in shape and very large. $85 \mathrm{cts}$. for $10 ; \$ 6.50$ per 100 .

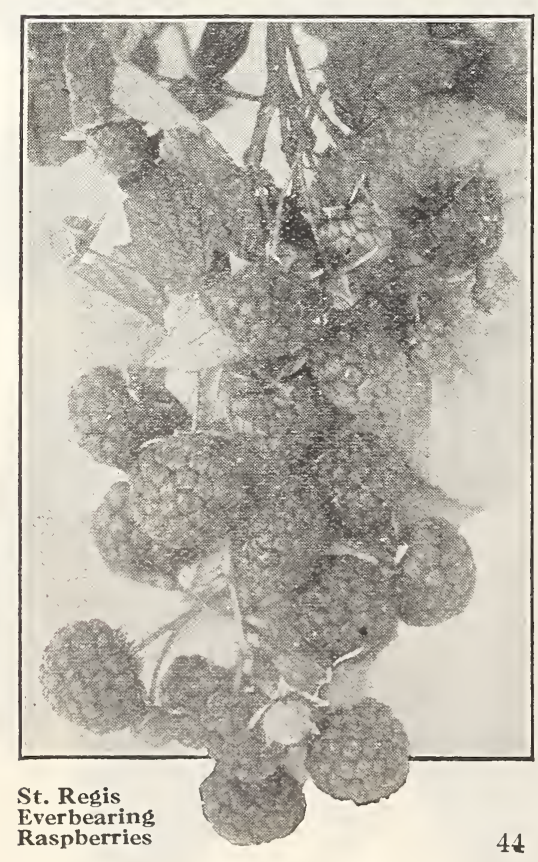

CUMBERLAND. Black. This is a cap variety and the largest of all the black Raspberries. It is sweet and quite firm, and makes a good appearance. The season is medium early, and the plants are very hardy. 65 cts. for $10 ; \$ 4.50$ per 100 .

Cuthbert. Red. The leading red Raspberry, the standard main-crop variety. It is very productive of large, conical, rich crimson berries, and altogether it presents a very handsome appearance. The flavor is delicious and the fruit as a market berry and a shipper has no superior in red Raspberries. The season is medium to late. 75 cts. for $10 ; \$ 5.50$ per 100 .

GOLDEN QUEEN. Yellow. The best of the yellow sorts. It is large, sweet, and juicy and of excellent quality. Season medium to late. This makes a very beautiful dessert when served on the table. $\$ 1.00$ for 10 , $\$ 8.50$ per 100 .

Quantity prices on application. 
GREGG. Black. One of the best known of the late varieties. It is a good shipper and one of the best for evaporating. The plant is a strong, vigorous grower and on good soil produces large berries which are firm, meaty, and of fine flavor. It is a profitable market berry. $65 \mathrm{cts}$. for 10 , $\$ 4.50$ per 100 .

KING. Red. This is the earliest Raspberry. The canes of the plant are hardy and very productive. The berry is round, of large size, and of a light crimson color, being a good shipper in the bargain. The quality is good. 75 cts. for $10, \$ 5.50$ per 100 .

Marlboro. Red. As a shipper it is unsurpassed and noted for its firmness. The berries are fine, large, juicy ones and ripen early. The bush is an upright and vigorous plant. $65 \mathrm{cts}$. for $10, \$ 4.50$ per 100 .

SPECIAL RASPBERRY OFFER
$\begin{aligned} & \text { Four each of Cumberland, Cuthbert and St. Regis Everbearing, } \\ & \text { twelve strong plants for } 90 \text { cts., postpaid. }\end{aligned}$

PLUM FARMER. A black variety that has come to stay as a market sort. Berries are thick meated, juicy, and firm, making it a good berry to evaporate or to ship to distant markets. There is no fruit more in demand than blackcaps, and if you have well-drained soil to plant them on, your returns will be sure to be good. This is a very superior kind and much more valuable than some of the other blacks. Season early. $65 \mathrm{cts}$. for 10, $\$ 4.50$ per 100 .

ST. REGIS. Red. This is the only variety that produces a crop the same year that it is planted and two crops a year thereafter. Many growers in New Jersey have averaged over $\$ 400$ per acre from this variety. About the middle of August it commences to set fruit on the young canes and bears continuously until frost. The berries are large, beautiful, and attractive. St. Regis is one of the best for a main crop and is not in the least affected by its fallbearing qualities. 75 cts. for 10 , $\$ 5.50$ per 100 .

Shaffer's Colossal. Purple. A very large berry of dull purple color, medium firmness, but of such fine flavor that it is unrivaled for table use and for canning. Season late 85 cts. for $10, \$ 6.50$ per 100 .

Quantity prices on application.

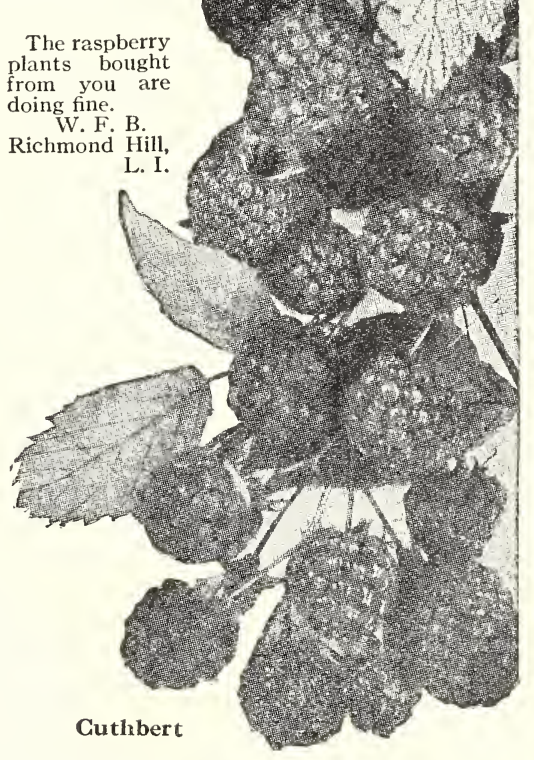

\section{Gooseberries}

People are just realizing the great value of the Gooseberry, single bushes of which yield a half bushel or more of berries a season. The great plantations of New York and Indiana have made some remarkable records, as well as our own fields containing over 20,000 bearing plants.

We recommend for field culture the Downing and the Houghton. Plant them 4 feet apart and 5 feet between the rows, making a total of 2,175 to the acre. For garden culture, plant them 3 feet apart, and 4 feet between the rows. Gooseberry jam is fine in the winter.

DOWNING. Large berries, solid and very firm. The bush is unusually free from mildew. It produces great quantities of large light-colored berries, of excellent quality. It is one of the oldest and most widely grown varieties, and is valuable for shipping, even for great distances.

HOUGHTON. Very productive; the berry is of medium size, and for general purposes is one of the best varieties. It is about as healthy and as hardy as any kind, and almost always produces a full crop. When the berry is ripe it is a good red, and is sweet and good. It is a strong grower and very prolific. It is entirely free from mildew.

Price of Gooseberry Plants: 30 cts. each; $\$ 2.75$ for $10 ; \$ 25$ per 100 . 


\section{BLACKBERRIES}

\section{-A PROFIT GROP}

Fertile soil makes Blackberry Plants produce enormous crops. Cultivation and fertilization of the ground will reward the grower. Our plants are grown from root cuttings and are very desirable. For commercial planting we advise Blowers, Eldorado and IVard. Set plants $3 \times 6$ feet apart. For garden planting, Blowers and Ward are best, $3 \times 5$ feet apart.

BLOWERS. This is one of the most remarkable new fruits ever produced. One single bush has been known to have produced 2,694 berries. It has the longest fruiting season of any Blackberry, lasting from July to October, producing its greatest crop in August, and much in September. It is very attractive for market both on account of its size and its excellent appearance. Usually sells at from one to two cents a quart higher than other kinds. $\$ 1.25$ for $10 ; \$ 8.50$ per 100 .

ELDORADO. The plant is very hardy and has not been known to winterkill in any section of the country. It enjoys entire freedom from rust. This berry originated in Ohio a few years ago and as fruited here is very productive. When sent to market it brings the best market prices. H. E. Van Deman, former U. S. Pomologist, writes: "I have gathered many wild berries, but never have I tasted anything equal to Eldorado." $\$ 1.25$ for $10 ; \$ 8.50$ per 100 .

ERIE. This is a hardy, vigorous grower and quite productive. Foliage clean and free from rust. Fruit large and of good quality. Considered a valuable market sort, as it brings good prices. $\$ 1.25$ for $10 ; \$ 8.50$ per 100 .

Iceberg. Here is a real creamy white Blackberry. The berry is about the size of the Snyder, has few seeds, and when fully ripe is quite sweet and delicious. Mixed with the glistening black ones in a dish they make a fine desert. The bushes are very productive. $\$ 1.25$ for $10 ; \$ 8.50$ per 100 .

Joy. This new berry is large and rich, almost as thick as it is long, is coal-black and has a rich, unsurpassed, luscious flavor. It is particularly hardy. Ripens midseason and produces great quantities of berries on all the canes. $\$ 2.00$ for $10 ; \$ 15.00$ per 100 .

Rathbun. Berries are large and of a glossy jet-black color. Its good flavor, small seed, and soft core make it a variety highly esteemed for quality. Its large, firm berries make it a good shipper. $\$ 1.25$ for $10 ; \$ 8.50$ per 100 .

Snyder. Firm berry, juicy, sweet, and of good quality. Exceedingly hardy and disease-resistant. A good market sort. $\$ 1.25$ for $10 ; \$ 8.50$ per 100 .

Ward. This is a vigorous grower and gives large annual crops of beautiful large berries. The fruit is black throughout, firm and good for shipment, yet tender and melting and of the best quality. This is more largely grown than any other variety. The plant is rust-resistant, and the berries are almost wholly without a core. Midseason. $\$ 1.25$ for 10 ; $\$ 8.50$ per 100 ; quantity prices on application.

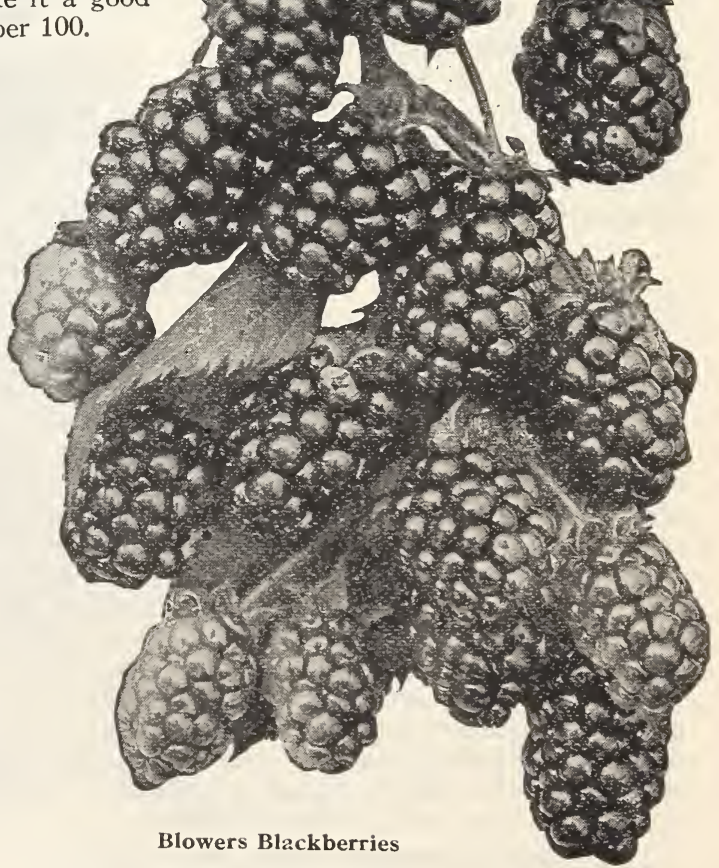


ARTHUR J. COLLINS \& SONS, INC.

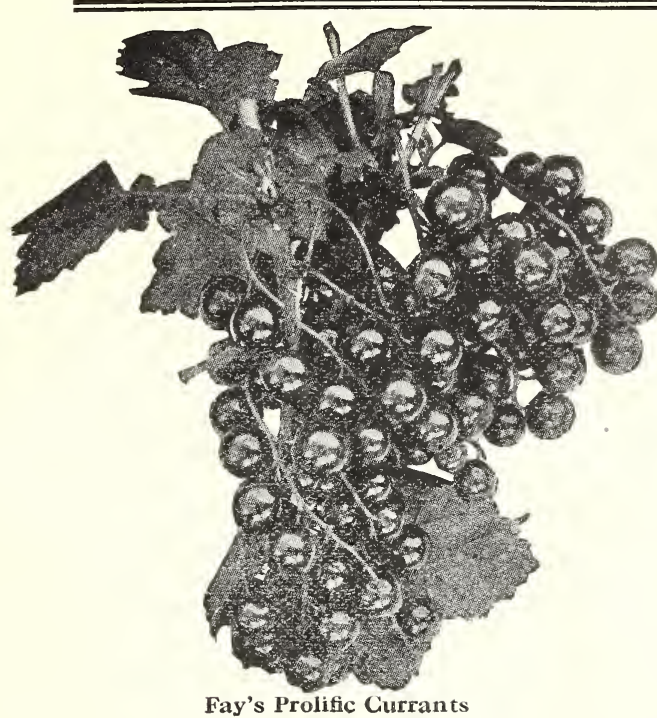

\section{GURRANTS}

Currants like best a very moist rich soil, and the plants for commercial planting should be set 4 feet apart and 5 feet apart between the rows. This requires 2,175 plants to the acre. We recommend President Wilder, Red Cross, and Victoria.

For the home-garden we recommend Fay's Prolific and Cherry. The plants should be set 3 feet apart and 4 feet between the rows.

CHERRY. The fruit is large, a deep red, and rather acid. The bunches are more compact and short, and the bush is thrifty. 40 cts. each, $\$ 3.00$ for $10, \$ 25.00$ per 100 .

FAY'S PROLIFIC. The berries are exceedingly large, and are mild and not so acid as the Cherry. A remarkable cropper. The bush is very vigorous. It is especially recommended for home use. Late. $40 \mathrm{cts}$. each, $\$ 3.00$ for $10, \$ 25.00$ per 100 .

\section{COLLINS GURRANT OFFER}

Six choice Currant bushes, three Fay's Prolific and three Cherry Currants for $\$ 1.75$ postpaid; value $\$ 2.50$.

Perfection. A superb variety with large long clusters of berries. It is quite popular, though a new berry. The fruit is bright red and grows to a large size. It has few seeds. The bush is a good grower and very productive. Quite early. 45 cts. each, $\$ 4.00$ for $10, \$ 35$ per 100 .

Pomona. Has the greatest actual acreage yield on record. Beautiful, bright, almost transparent red, has but few small seeds, and is much less acid than the other sorts. $35 \mathrm{cts}$. each, $\$ 2.50$ for $10, \$ 18.00$ per 100

PRESIDENT WILDER. Ripens at the same time as Fay's Prolific but hangs on the bush much longer if desired. This is a very prolific sort and has become quite popular for the market trade. The large bunches and berries are very attractive and red even when dead ripe. Late. 30 cts. each, $\$ 2.50$ for $10, \$ 18$ per 100 .

RED CROSS. The clusters are large, sometimes measuring 5 to 6 inches in length. The fruit is large and of good quality, mild, and subacid for a red Currant. Midseason. 35 cts. each, $\$ 2.50$ for 10 , $\$ 18$ per 100 .

VIGTORIA. The best late variety. The bunches are long and the pale red berries are of medium size. They are of superior quality. The bush bears profusely and is a good kind to plant to succeed the other varieties. $35 \mathrm{cts}$. each, $\$ 2.50$ for $10, \$ 18$ per 100 .

WHITE GRAPE. Large yellowish-white, transparent; juicy and rich. The fruit is sweet, and very fine for table use. Authorities pronounce it the largest and most productive of the WHITE Currants. $40 \mathrm{cts}$. each, $\$ 3.50$ for $10, \$ 30$ per 100 .

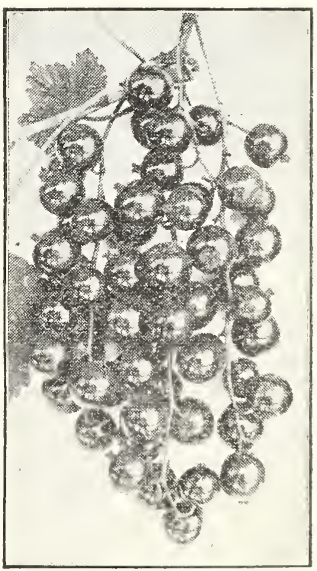

Cherry Currants

Dear Sir: Plant received this morning O. K. The stock you have furnished me with has alwiys been satisfactory.-W. W., Chestnut Hill, Pa. 


\section{Collins Good Grapes}

Grapes can be planted anywhere and will thrive with practically no attention. They will trail over an old back fence or the arbor. The side of your house will be equally attractive to them. Prune them back in the fall so they will keep young and thrifty. "Grape Culturist Book," see page 46.

\section{Quantity prices on application}

Collins "Adams Champagne" Grape. A splendid new Grape, worked up by Mr. Adams, in the greatest grape section of New Jersey, from whom we secured our original vines. Color appetizing pink or deep pink shading to red. Exceedingly strong grower. Grapes ripen about September 15 th, and last until after heavy frosts-splendid keepers. The solid, compact, large bunches are very handsome with a deliciously tempting odor. Tested for years, has never failed to bear. Three-year vines, $\$ 1.25$ each, postpaid; five for $\$ 5.00$ postpaid.

IVe have only a few vines, therefore, act now, it is unlikely that this offer will appear again.

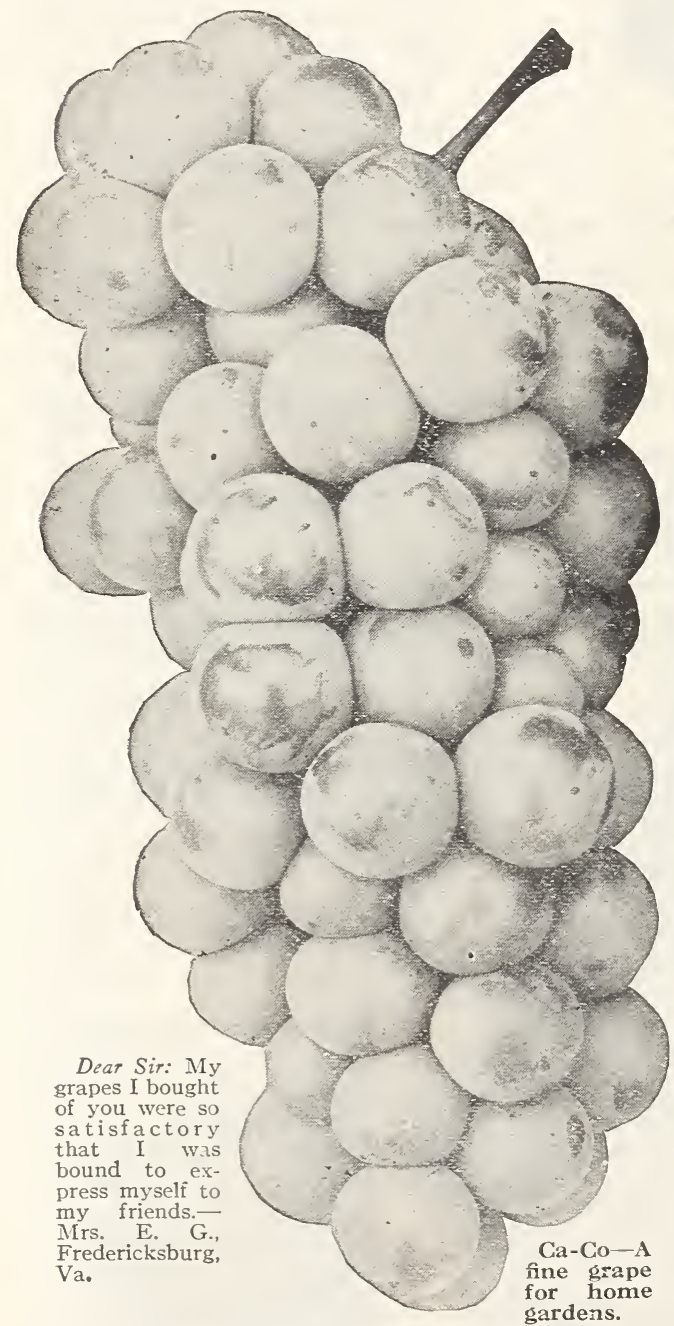

Brighton. Red. The bunch is medium to large, and is long, compact, and shouldered. The fruit is medium, tender, sweet, and with little pulp. The skin is thin, and this is one of the best early Grapes. 50 cts. each; $\$ 4$ for $10 ; \$ 30$ per 100 .

CA-CO. Red. This Grape is a cross between Catawba and Concord scientifically made, and possesses the merits of both varieties, with the defects of neither. Its good qualities are: High quality, surpassing in tenderness of pulp, luscious flavor and aroma of Catawba; rich, sparkling wine-red, with abundant bloom; bunch large and compact; berry medium to large and nearly round; season early, a little in advance of Concord; skin thin and tough; berry adheres firmly to bunch; a superior shipper and keeper; exempt from rot. The vine is very vigorous and a heavy, annual yielder. 85 cts. each; S7.50 for $10, \$ 60$ per 100 .

Campbell's Early. Black. This is hardy, healthy, and productive. The pulp is sweet and tender, having a sweet aroma, and of good quality when fully ripe. The bunch is large shouldered and compact. It adheres strongly to the stem, does not crack, is tough, and has a thick skin, which adds to its value as a market Grape. $50 \mathrm{cts}$. each; $\$ 4$ for 10 $\$ 30$ per 100 .

CATAWBA. Red. Tnis is the standard red market Grape. The pulp is sweet and the quality excellent. The bunch is large, moderately compact and shouldered. The berries are of good size and have tough skin. It adapts itself to almost any locality or climate, and is a good shipper and a long keeper. It is a good grower and is very hardy and productive. Late. 35 cts. each; $\$ 2.75$ for 10 ; $\$ 20$ per 100 .

\section{COLLINS SPECIAL GRAPE VINE OFFER}

We offer you six vines in all. Two plants each of the three most popular orapes for home-oardens-Catawba, Concord and Niagara for $\$ 1.50$ postpaid. (A $\$ 2.10$ value.) 
CONCORD. Black. This is without doubt the most popular market and garden Grape in America. The bunches are large, compact and shouldered. The berry is large, juicy and sweet, and excellent for grape juice. The vine is quite insect and disease resistant. It ripens early to midseason, maturing its fruit before frost. Our plants have a splendid rootsystem. $30 \mathrm{cts}$. each; $\$ 2.25$ for $10 ; \$ 18$ per 100 .

Delaware. Red. Is attractive, keeps well on the vine and in the box;

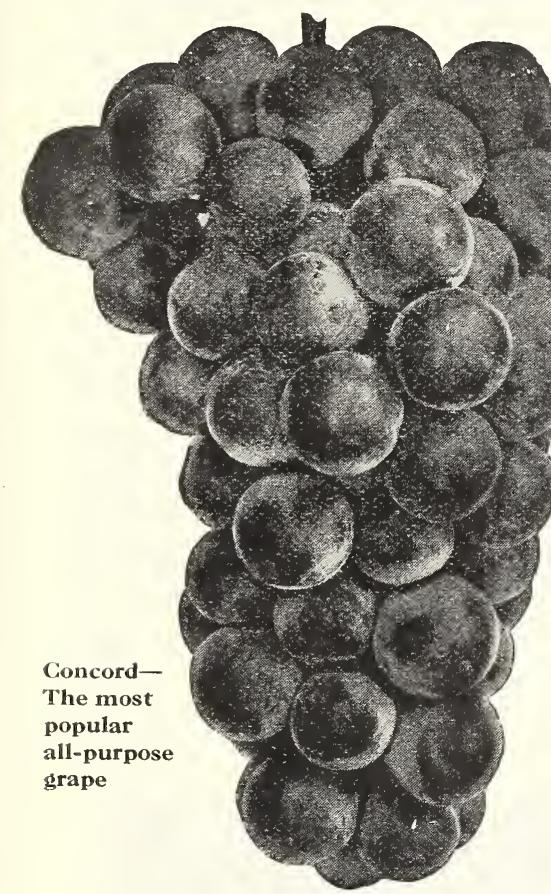

is free from the black rot, all of which goes to make it an excellent market Grape. Bunch small and compact, berries small, but juicy and sweet, with thin but tough skin. $50 \mathrm{cts}$. each; $\$ 4.00$ for $10 ; \$ 30$ per 100 .

HUBBARD. Sweet, delicious, with fine flavor. Seeds few and small, pulp tender, skin thin and firm. Berries and bunch large and uniform. Ripens ten days ahead of Concord. Truly a wonderful grape. Said by some to surpass the Concord and Niagara. 85 cts. each; $\$ 7.50$ for $10 ; \$ 60$ per 100 .

Moore's Early. Black. Ripens two or three weeks earlier than the Concord. The berries are larger but the bunch is somewhat smaller than that of the Concord. The skin is thin, the flesh is sweet, and the quality is good. 50 cts. each; $\$ 4$ for $10 ; \$ 30$ per 100 .

NIAGARA. White. The bunch is large and handsome. It is compact and sometimes shouldered. The berries are large and very sweet. The skin is thin but tough, and the bunch makes a fine appearance. This is the standard white Grape and we think it will continue to be so for some time. The vine is vigorous and comparatively free from disease, though it responds well to care. $35 \mathrm{cts}$. each; $\$ 2.75$ for $10 ; \$ 20$ per 100.

Pocklington. Pale green. The bunches are large and compact, and the berries are very large, being covered with a beautiful white bloom. The quality is good and it ripens soon after the Concord. Very hardy and productive. The skin is thin and the flesh is sweet and juicy and a little foxy in flavor. 50 cts. each; $\$ 4$ for $10 ; \$ 30$ per 100 .

Salem. Dark red. The bunch is large, compact, and shouldered. The berries are large and round, having a thick, firm skin. The flesh is very sweet and tender. Earlier than the Concord. Hardy and vigorous. $50 \mathrm{cts}$. each; $\$ 4$ for $10 ; \$ 30$ per 100 .

Worden. Black. A close rival to the famous Concord. The grape and the bunches are larger, the fruit is of better quality. The pulp is very tender. A very popular grape. Hardy and vigorous. 50 cts. each; $\$ 4$ for $10 ; \$ 30$ per 100 .

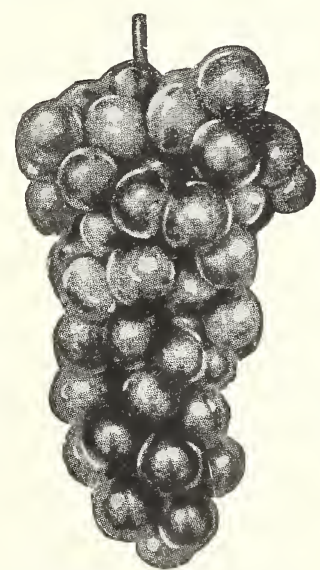

Niagara-1/4 natural size

Wyoming Red. Light red. This ripens with the Delaware which it much resembles in appearance, though the bunch and the berries are larger. The berries are sweet and pulpy, and the vine is a good strong grower. 50 cts. each; $\$ 4$ for $10 ; \$ 30$ per 100 .

\section{COLLINS DOLLAR GRAPE VINE COLLECTION}

Five Splendid Concord Grape Vines 2 years old for $\$ 1$ postpaid. Plant Collins Big 2-yr. Vines, pick grapes the following year. (Train them over that back fence you have neglected so long.) 


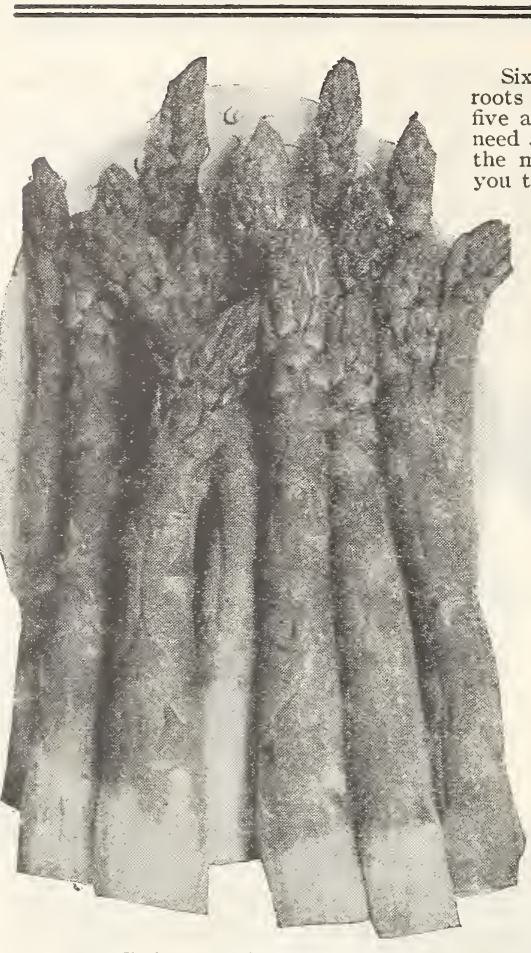

Palmetto Asparagus

Sixteen years ago I bought sufficient asparagus roots from you to set 65 acres of asparagus. Twentyive acres of this planting $I$ am still cutting. I will need 50,000 selected one year old roots, not later than That strain of roots have ou to offer.-W. F. R., Tyler, Texas.

\section{Asparagus Roots}

(Asparagus is good for the system)

Asparagus is growing more popular each year both as a crop for market and for home gardens. It is easily raised and a bed once established is good for 15 to 20 years. Lately, Asparagus has been selling at a very good price, $\$ 250$ to $\$ 300$ per acre, and being ready for market in April and May, the income derived from it is especially appreciated at that time of the year. Collins Asparagus roots are grown on new land and we give them plenty of manure, which makes the roots healthy and vigorous, and able to produce for many years.

Asparagus does well on all good garden soils, but earliest crops come in light soil. Plant in Spring in a trench of earth 8 to 10 inches deep, covering with 2 inches of earth, filling in trenches gradually as plants grow. Set 18 to 20 inches apart in rows; rows 4 to $4 \frac{1}{2}$ feet apart-6,220 plants to the acre.

(For valuable book on Growing Asparagus see page 65.)

Barr's Mammoth. Early and very large. Produces heavy stout spears of delicious flavor. The growth remains green when cooked.

Conover's Colossal. Very large and makes a rapid growth. Quality excellent; planted mostly by marketgardeners, and is very productive.

Giant Argenteuil. This variety excels in productiveness and earliness. It has been found to be particularly disease-resistant. In size it is a giant, a single shoot or spear being 2 inches in diameter, and from 10 to 12 inches long. It succeeds well in all climates and in color is white with a purple tip.

Palmetto. Very early, even and regular in size, and of excellent quality. Hardy and very prolific. Brings top prices in markets.

Come, see our half million fine roots.

Owing to the abundant rain last summer our roots made a particularly fine growth, and they are large and well developed. We have a very big stock of roots and shall be glad to quote in larger quantities than here offered, for immediate shipment.

Dear Sirs: I ordered 200 asparagus roots of you last year and in spite of the drought. I never saw such prolific shoots. They stood $3 \mathrm{ft}$. high when frost came, and we will be able to use the shoots this spring. Please send me your catalog.-Mrs. F. E. D., Ypsilanti, Mich.

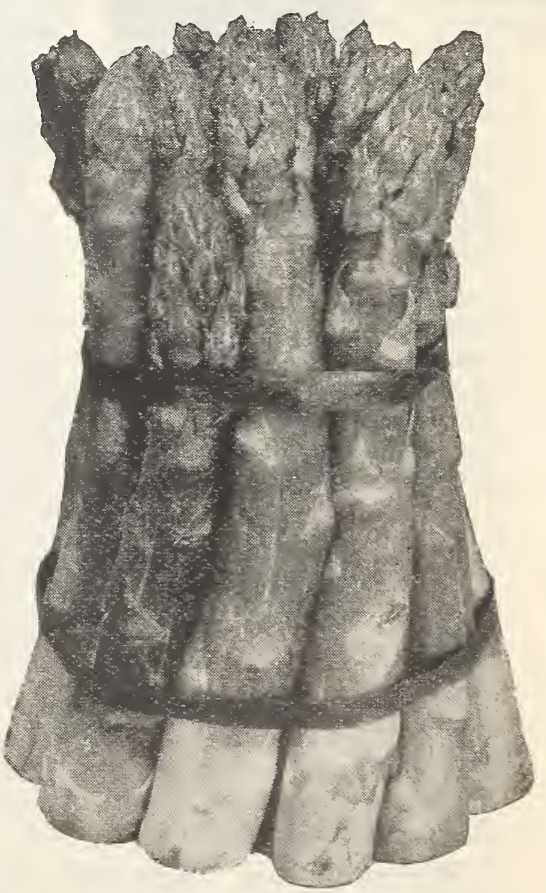

Giant Argenteuil Asparagus

\section{PRICE OF COLLINS ASPARAGUS ROOTS}

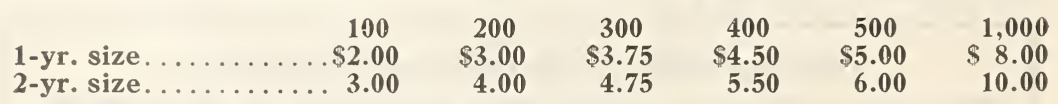

A11 above prices by express-see page 67 .

Yield $\$ 250$ to $\$ 300$ per acre-good for 15 to 20 years 


\section{Collins Pedigreed Mary Washington Asparagus-Rust-Resistant}

The United States Department of Agriculture carried out a most painstaking and careful plant-breeding program which was designated primarily to eliminate asparagus rust, and as a result the strain or variety known as "Washington Asparagus" was originated and introduced. This new strain is so much better than any other asparagus, that it seems to be in a class by itself. The Bureau of Plant Industry circular says, "The shoots are very large on the average, with a tendency to be oval in cross section, very early and prolific. The highbranching habit of this strain makes it possible to cut unbranched shoots with good tight buds as much as two feet long. This strain suffers no appreciable loss under severe rust conditions."

We guarantee our roots to be from the true Mary Washington seed-beware of imitations-and our strain has been selected from seed fields composed of the plants that produce large straight shoots, dark green in color with a heavy purple over-tone, the tips are tight and firm and do not open or begin to branch until well out of the ground, which makes this strain especially satisfactory for every use. As a standard variety for fancy asparagus for the home garden as well as the market, it stands above all other varieties in size, vigor, tenderness, quality and rust-resistance. This new strain of asparagus is an innovation in asparagus growing and without a doubt will supplant all of the other kinds in the very near future, as soon as enough stock can be produced to supply all of the demand. We have only a limited supply of roots, not nearly enough to meet the demand this spring. Order early.

\section{Utilize Your Spare Garden Space}

100 Roots of Asparagus on a plot of ground 15 feet by 15 feet (six rows $1 \frac{1}{2}$ feet apart) or 9 feet by 25 feet ( 10 rows $1 \frac{1}{2}$ feet apart).

Every garden has at least this small amount of spare space that ought to be growing tender, juicy Asparagus. A bed like this supplies the average-sized family, producing for 20 years or more, almost without care. "The kind you raise beats the kind you buy." Cut it fresh just before cooking.

Collins offer Pedigreed Mary Washington Asparagus Extra Selected Roots

100 Fat, thrifty Roots, 3-yr. size....\$2.50 Postpaid 100 Fat, thrifty Roots, 2-yr. size... 2.00 Postpaid 100 Fat, thrifty Roots, 1-yr. size... 1.75 Postpaid

Note. We offer Martha Washington at above prices in 2-yr. size and 1-yr. size only.

Mary and Martha Washington Roots in any quantity - fresh dug-write for new low prices.

SHA $D$ (Reselected) of either Mary or Asparagus, at $60 \mathrm{cts}$. per packet contains enough to grow more than 100 roots.

\section{Horse-Radish}

This is used in almost every household, especially in the Fall and Winter months when the fresh product is ready. Set the roots in the spring about 6 inches apart. Practically no attention is necessary; in the Fall lift as many roots as you will need, allowing rest to remain in the ground. A bed once started is good for several years. $50 \mathrm{cts}$. for $10 ; \$ 3$ per 100 .

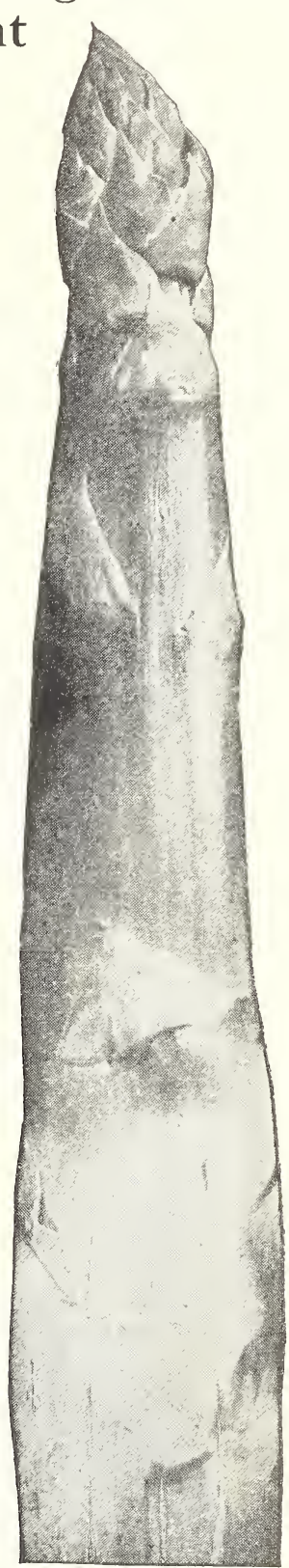

An ideal shoot of Pedi greed Mary Washington Asparagus. This shoot was nearly two inches in diam eter. For high-grade tender asparagus this type is far superior to the ordinary strains developed in Europe for growing bleached ase paragus.

\section{Rhubarb or Pie-Plant}

Rhubarb can be planted either in the Fall or the Spring, is very hardy and needs little or no attention. Plant 4 feet apart and in fertile soil. The kinds listed below grow very quickly and will produce abundantly for many years.

Myatt's Linnaeus. This is early, large, tender, and of good quality.

Victoria. Immense stalk of cherry-red color, which cooks fine, having no strings or coarse matter. Of fine quality and tender. A very popular sort.

Prices of Rhubarb, $\$ 1$ for $10 ; \$ 7$ per 100 postpaid. 


\section{Collins Quality Apple Trees}

On these two pages we offer you the leading varieties of standard Apple Trees. Collins trees are healthy, they have good roots and tops, and are clean and vigorous. Plant an APPLE TREE in your garden, a strong, sturdy tree, you will soon enjoy its fruit-so will your children and your children's children. That means fresh fruit to eat when you want it, and pies and sauces and jellies unending.

We are extensive fruit-growers ourselves having over 16,000 Apple Trees in our own orchards, and we shall be glad to offer you suggestions and help you where we can. We believe in our own trees-have planted them in our

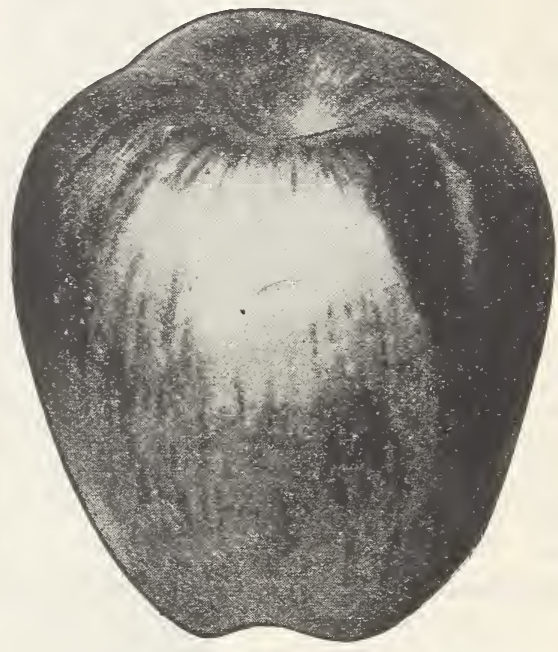

Delicious-all that the name implies own orchards for over 60 years.

Most Popular Varieties are listed in CAPITAL letters.

Plant Apple Trees $20 \times 20$ feet, requiring 110 trees to the acre.

BALDWIN. Winter. Large; deep red, crisp, juicy, and rich flavored.

DELICIOUS. Autumn. Fruit large, nearly covered with brilliant dark red; flesh fine grained, crisp and melting; with delightful aroma; very highest quality; a splendid keeper and shipper; tree one of the hardiest.

Duchess. Summer. Good size yellow striped with red; juicy and subacid; a tremendous cropper. Does not bruise-is a good shipper

Early Harvest. Summer. Medium; pale yellow; tender and good. Good throughout the northern states and the northwest.

Gano. Winter. Dark red; flesh pale yellow, tender, mild, and subacid. It is a good keeper. Tree a rapid grower. Fruit large and even in size.

GRIMES GOLDEN. Fall and winter. A fine table and cooking Apple; yellow, rich and tender. When fully mellowed, it is one of the best eating Apples grown. Tree very productive; Apple large and of splendid flavor; a good keeper.

JONATHAN. Winter. A beautiful red Apple, highly flavored, tender, juicy, spicy, and rich; splendid for family use and highly profitable for market; tree long lived, productive and an early bearer. (See cut.)

King of Tompkins County. Winter. Extra-large size; a beautiful red in color, striped with yellow. It is one of the best; tree a vigorous grower.

Maiden's Blush. Autumn. Large; greenish white with a beautiful blushed red cheek; tender and pleasant but not high flavored; good bearer. Mammoth Black Twig. Winter. Dark red; a very good winter apple

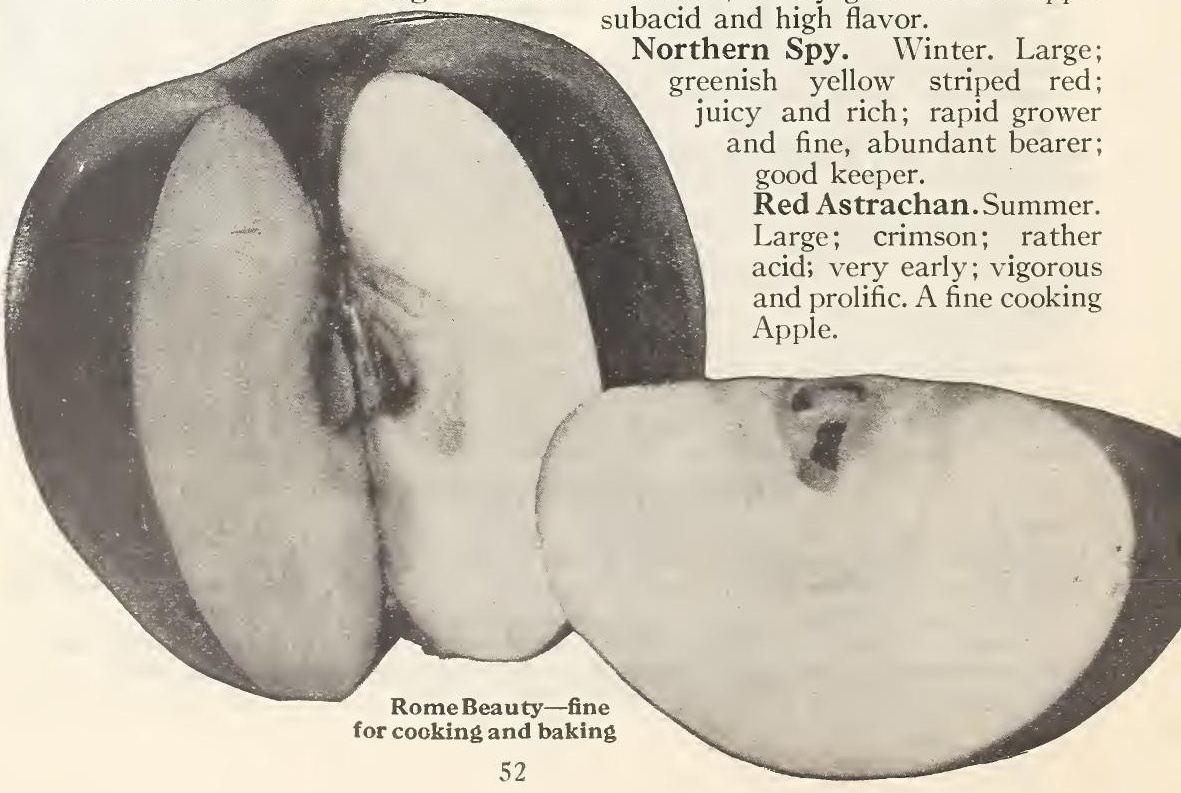


ARTHUR J. COLLINS \& SONS, INC.

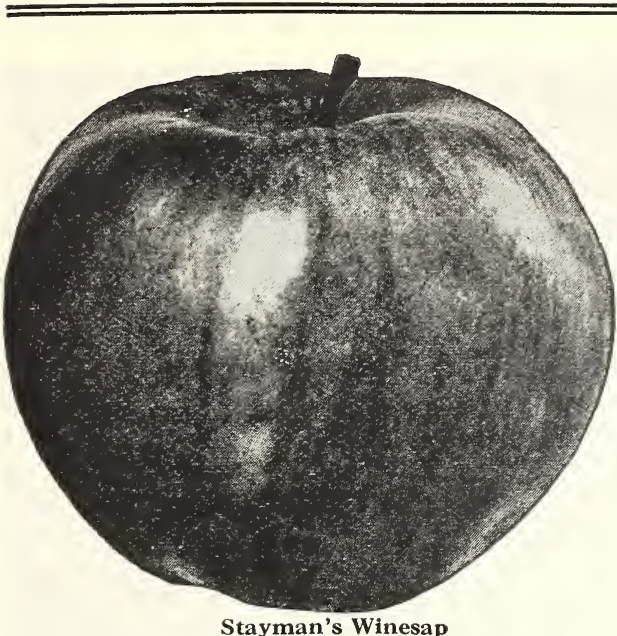

Rhode Island Greening. Winter. Large, greenish yellow, tender, juicy, and good; flesh yellowish, firm, fine grained, crisp and subacid; tree vigorous and wide spreading.

ROME BEAUTY. Winter. Large; an exceedingly beautiful Apple of pale yellow shaded with red; tender, juicy, good, and profitable. Quality and flavor way above the average; always sells well. Free abundant cropper.

STAYMAN'S WINESAP.

Winter. In appearance and flavor this is one of the best Apples grown. It is quite juicy and is a favorite for making cider. Of medium size, conical, and mostly covered with red and yellow markings. Flesh fine, crisp, and of fine flavor. This will keep well till the following April, if kept in a cool place and not disturbed.

WEALTHY. Summer and fall. Large size when full grown. Abundant cropper through a long season. Fruit red with white streaks; quality good; full of juice; an excellent cooker; fine for sauce or pies. Tree a good grower and quite hardy. Bears early and is a fine shipper.

\begin{tabular}{|c|c|c|c|c|}
\hline $\begin{array}{l}\text { le Trees } \\
\ldots \ldots \ldots \ldots \ldots\end{array}$ & $\begin{array}{l}\text { Each } \\
\$ \quad .70 \\
.85 \\
1.00\end{array}$ & $\begin{array}{c}10 \text { Trees } \\
\text { One Kind } \\
\$ 6.30 \\
7.65 \\
9.00\end{array}$ & $\begin{array}{c}50 \text { Trees } \\
\text { One Kind } \\
\$ 28.00 \\
34.00 \\
40.00\end{array}$ & $\begin{array}{l}5 \text { at } 10 \text { rate } \\
\text { Quantity } \\
\text { Prices on } \\
\text { Application }\end{array}$ \\
\hline
\end{tabular}

\section{COLLINS LONG-SEASON APPLE TREE OFFER}

Five largest size splendid trees for the garden; Stayman's Winesap, Rome Beauty, Wealthy, Grimes Golden and Delicious, the five leading varieties for $\$ 4.25$. (Regular price $\$ 5.00$.) A fine succession of luscious apples. Every variety a tremendous cropper.

YELLOW TRANSPARENT. Early. Skin clear white, pale yellow when ripe; flesh white and very tender, juicy, subacid, and of fine quality. A productive, excellent, and quite popular variety.

York Imperial. Winter. Medium to large; white shaded crimson; crisp, juicy, subacid, and of fine quality. Tree is a very thrifty, hardy grower. Prolific.

\section{CRAB-APPLE TREES}

These trees are very productive and bear when quite young. The trees may be planted on the lawn, as they are very ornamental when in bloom and their fruit shows up fully when ripe. Crab-apples are excellent for preserves and jellies, make good cider, and some varieties are fine for eating.

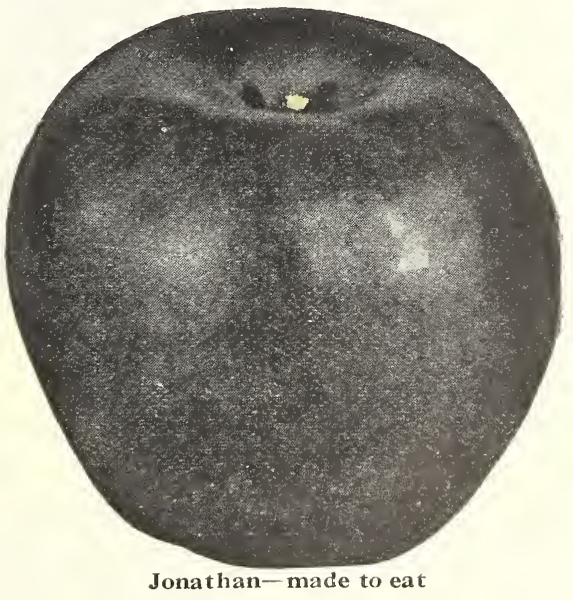

Hyslop. Large; deep crimson, and most beautiful. October.

Transcendent. Large; red, showy, and excellent. Sept. and Oct.

$\$ 1.00$ each; $\$ 9.00$ for 10

Parcel Post Size Apple Trees offered on page 66. 


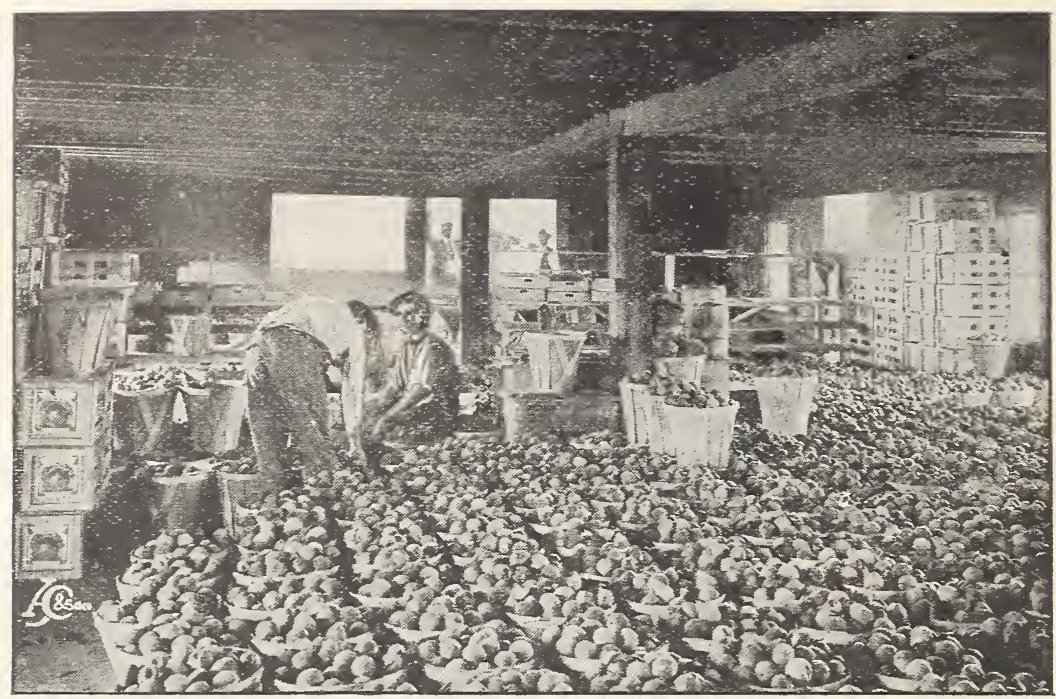

This is the way our own trees produce. An August scene in one-of our large packing-houses

\section{Peaches That Pay Profits}

If you have only a small farm or a little garden space that will grow a tree, by all means plant Peach Trees. They soon pay for themselves. Collins Peach Trees yield over half a bushel per tree the third year-they can do it because we grow them with good roots and free from disease-they're fine young stock and thrifty. Have fresh peaches in your garden and sell the surplus to your neighbors.

Plant them $16 \times 18$ feet apart requiring 150 trees to the acre.

BELLE OF GEORGIA. Free. White. Very large. Skin white with red cheek. Thite, firm flesh of excellent flavor. Very prolific. July.

GARMAN. Cling. IThite. Large; resembles Elberta. Skin tough, creamy white, with deep blush; flesh creamy white tinged with red. Flavor

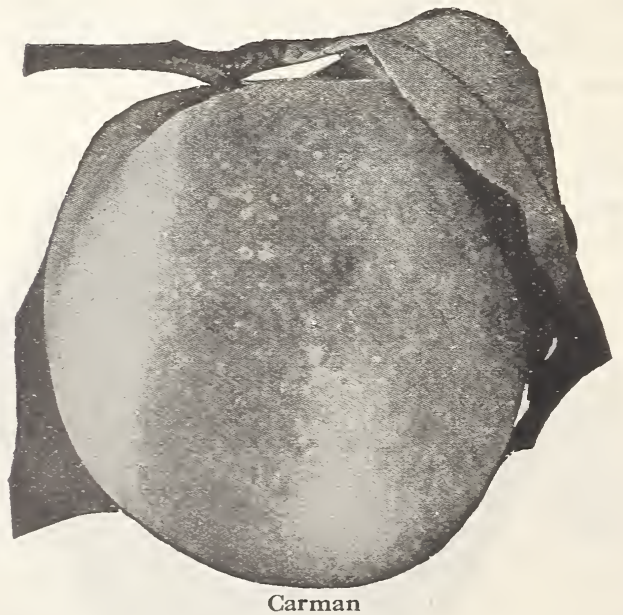
good; a good shipper. Early; August.

Champion. Free. White. Large size; red cheek; delicious flavor; full of rich, sweet juice. Extremely hardy. Late August.

Crawford's Early. Free. Yellow. A fine big yellow Peach with red cheek: oblong; flavor excellent; healthy grower. First of September.

CRAWFORD'S LATE.

Free. Yellow. The fruit is of large size, the skin yellow with red cheek, the flesh is yellow, rich, and juicy. The tree is vigorous and is moderately productive. Last of September.

ELBERTA. Free. Yellow. The leader of all Peaches and the greatest commercial variety on the market, over 50 per cent of the Peaches planted being Elberta. This will thrive where any Peach can be grown. A beautiful Peach of good quality; not only the best orchard variety, but also valuable for the garden. It is large, yellow, has a red cheek, and is good and juicy with a high flavor. A fine variety for canning. The Elberta is hardier in bud than many varieties and therefore a more uniform cropper. Early September. 
GREENSB ORO. Free. White. Round. Flesh very juicy and of medium quality; skin white with red cheek. Free from rot. Late July.

Hale. Free. Yellow. Ripens just before Elberta; better in quality and usually larger. Yellow and deep red. Medium producer. Early September.

H ILEY. Frees tone. White. A large white Peach with a beautiful red cheek; the flesh is juicy, tender, and white. The tree is a prolific bearer and the fruit ripens early, is also a valuable market sort. Bears in early July.

I RON MOUNTAIN. Free. White. Size enormous, egg-shaped; color pure white, with slight blush; good quality; good keeper; very regular bearer. October.
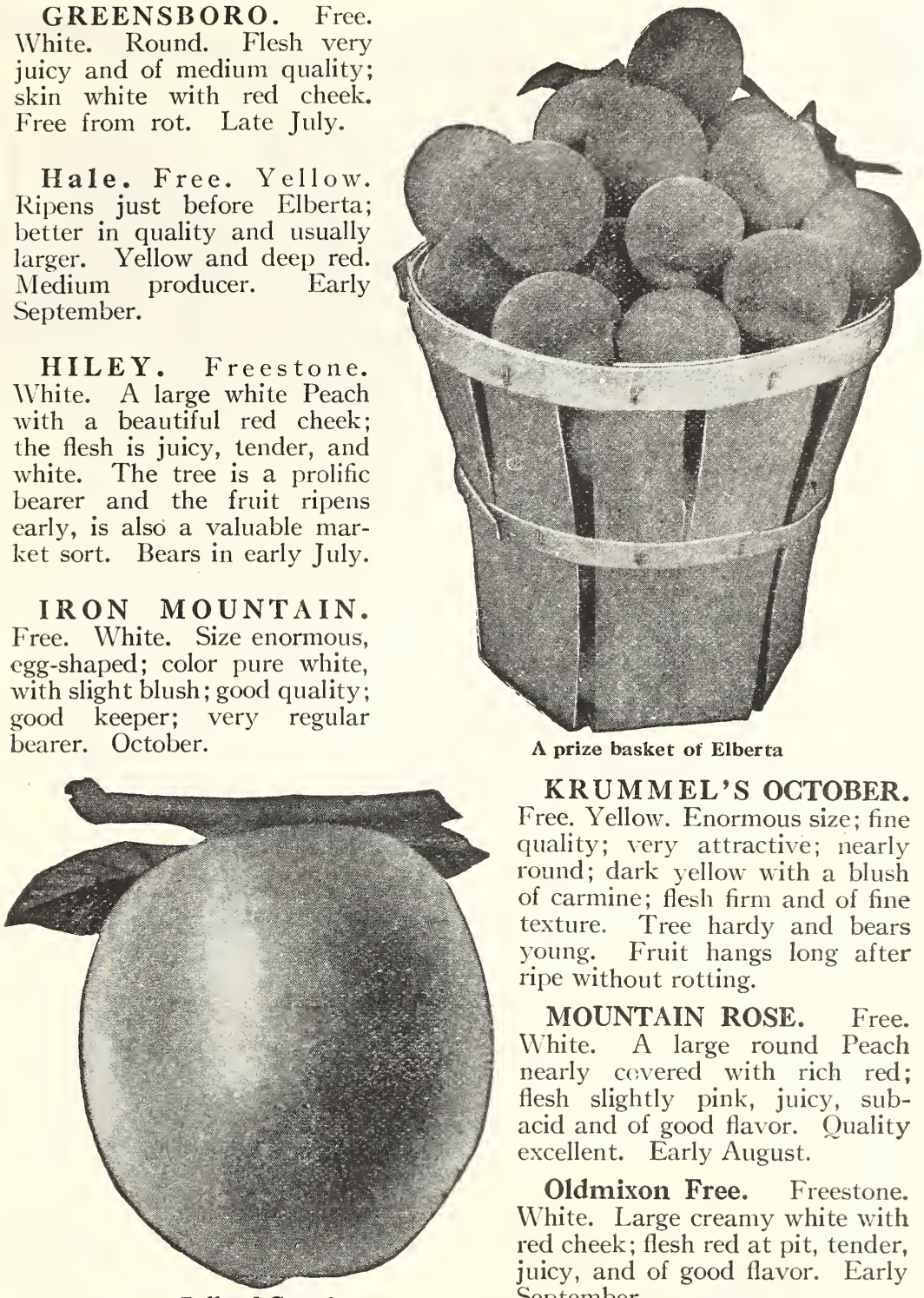

A prize basket of Elberta

KRUMMEL'S OCTOBER. Free. Yellow. Enormous size; fine quality; very attractive; nearly round; dark yellow with a blush of carmine; flesh firm and of fine texture. Tree hardy and bears young. Fruit hangs long after ripe without rotting.

MOUNTAIN ROSE. Free. White. A large round Peach nearly covered with rich red; flesh slightly pink, juicy, subacid and of good flavor. Quality excellent. Early August.

Oldmixon Free. Freestone. White. Large creamy white with red cheek; flesh red at pit, tender, juicy, and of good flavor. Early September.

Red Bird Gling. Cling. White. Glorious color and splendid quality make it one of the best Peaches. Does not bruise and is a good shipper. Beautiful Peach. Last of July.

Salway. Free. Yellow. Large; beautiful; hardy. October.

Stump the World. Free. White. Large; white with red cheek; juicy and of fine quality; very productive and profitable. Last of August.

\section{COLLINS ALL-SEASON PEAGH TREE OFFER.}

Includes the 5 leading varieties of Peach Trees for the Home Garden; Hiley, Belle of Georgia, Elberta, Iron Mountain, and Crawford's Late, all strong, largest size trees for \$3.25. (Regular Price \$3.85.)

Peach Trees by Mail. For remarkable offer see page 66. 


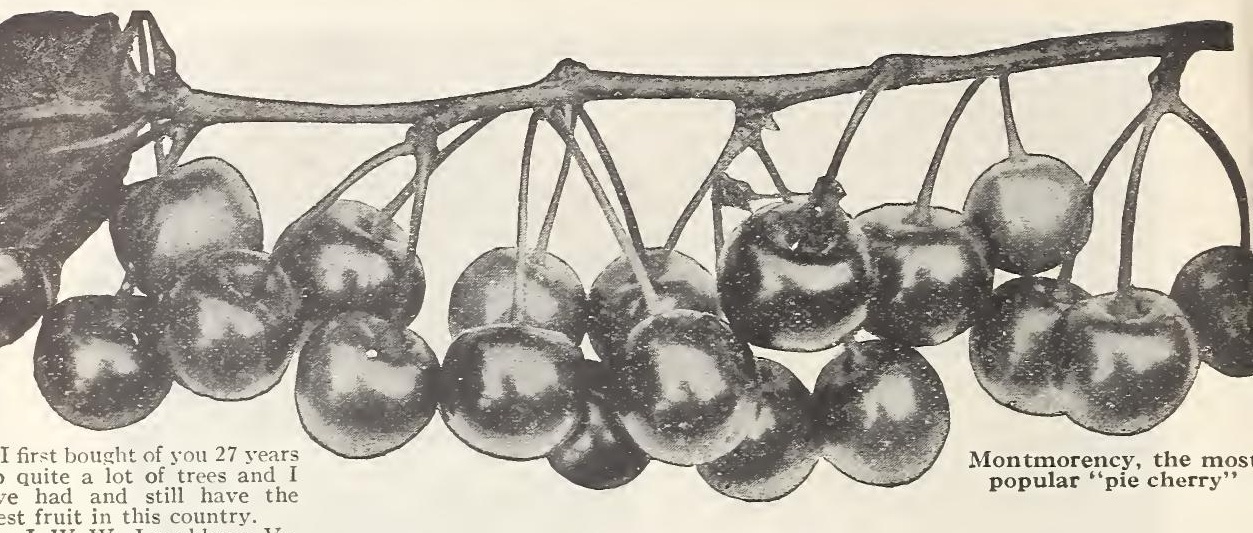
had and still have the J. IV. W., Lynchburg, Va.

\section{CHERRIES}

The Cherry is one of the most profitable fruits under cultivation. Enormous profits are being realized from young orchards, for they come into bearing at an early age and yield abundantly. They require the least attention of any fruit, and are ideal for the home-garden.

Commercial Planting. IVe recommend Early Richmond and Montmorency as sour varieties, and the IVindsor as a sweet kind. Plant them 16 feet apart by 18 feet between the rows, or 150 to the acre.

Garden Culture. IVe recommend Montmorency, IVindsor, and Governor IVood. The trees need little or no attention, and are rapid and hardy growers.

\section{SPECIAL CHERRY TREE OFFER.}

One each of Montmorency, Windsor and Governor Wood, three Cherry trees in all, for $\$ 3.20 \mathrm{f}$. o. b. Moorestown. All largest size trees. Excellent assortment. Regular value \$3.75.

Baldwin. Sour. Large, round, dark wine color, sweet and rich. Early. hardy, and very productive. June.

Black Tartarian. Sweet. Fruit is purplish black, and is large and of sweet, jelly-like consistency. Tree makes a fine erect growth: produced in immense crops.

EARLY RICHMOND. Sour. Fruits soon after planted, and is an unusually heary cropper. The most hardy of all rarieties and is uninjured

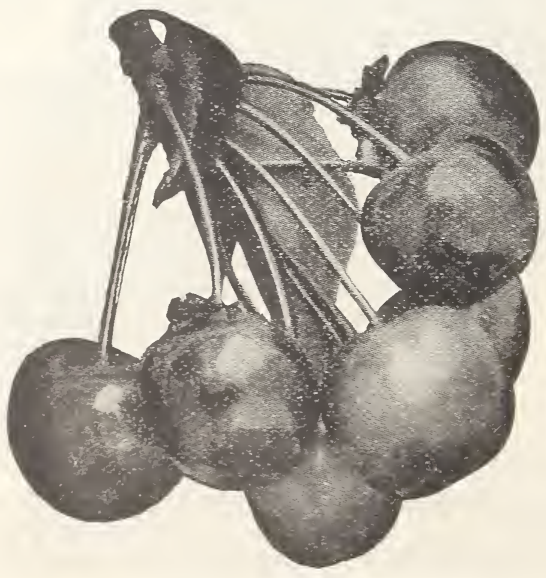

Early Richmond Cherries by the coldest winters. Fruit is medium size, round, and dark red. Flesh is tender, juicy, and subacid. Earlier than Montmorency.

GOVERNOR WOOD. Sweet. One of the best Cherries. Very large; light yellow marbled with red; juicy, rich, and delicious; tree healthy and a good bearer; fruit hangs well on the tree. Ripens the last of June.

May Duke. Sour. Large, red, juicy and rich, and is not as sour as some varieties, which makes it more in demand. June.

Gentlemen: I have received the shipment of trees and berry plants and find them all very good specimens.-B. W. H., Newark, N. J. 


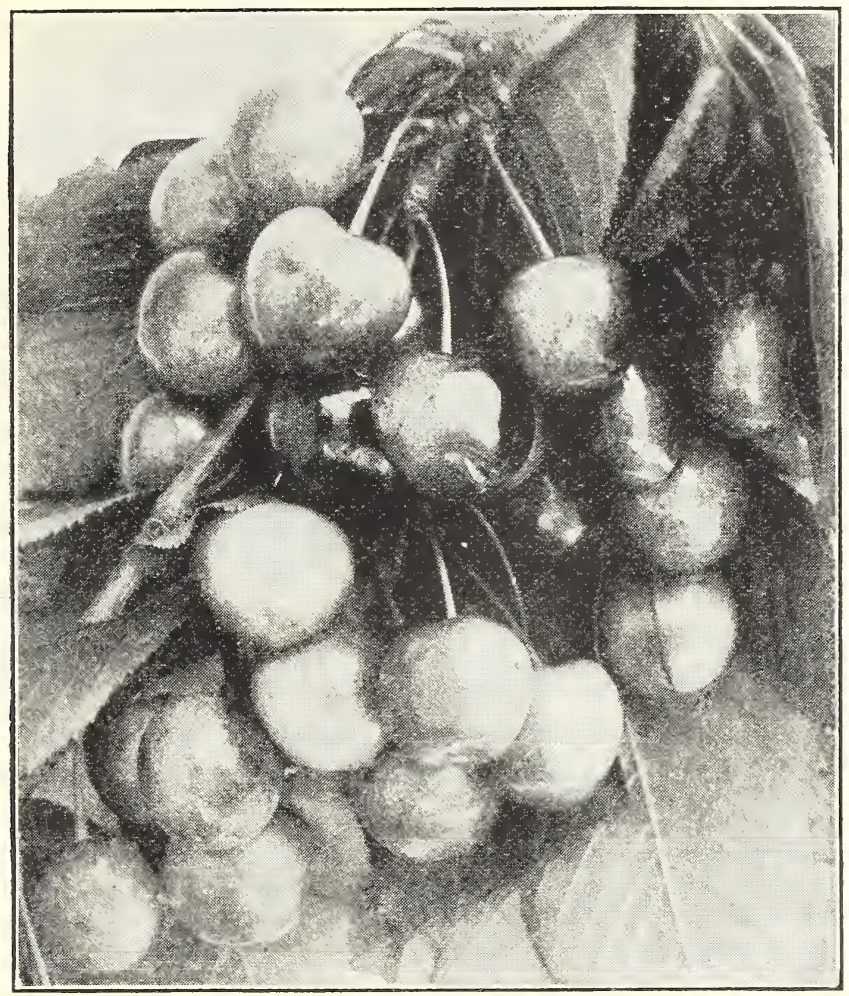

Collins Luscious Oxheart Cherries

MONTMORENGY. Sour. Late. A beautiful large red Cherry, much larger and firmer than Early Richmond, and fully ten days later in ripening. The best for canning and preserving. It is THE sour Cherry, and the fruit is in great demand wherever grown.

Napoleon. Sweet. Tree medium size and erect. Fruit borne usually in pairs, very large and oblong; light yellow, with red cheeks where the sun strikes them; fruit solid, and red at the stone. A fine bearer.

OXHEART. Sweet. Large; light with red cheek; solid, meaty, rich and excellent. Always in demand, bringing top prices.

WINDSOR. Sweet. The tree is vigorous and hardy, and bears early. The Cherries are heart-shaped, dark purple, and the flesh is quite firm, fine in texture, and rich in flavor. Ripens early. Fruit is large and will hang on the tree a long while without rotting.

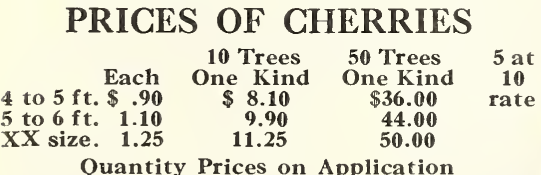

\section{Dwarf Rock Mountain Cherry}

Ideal for the home-garden. Its fruit is jet-black and medium in size. The tree grows dwarf, and is hardy. It gives much fruit at the age of two years. The plants are of bushy habit, from 2 to 4 feet high. $\$ 1.00$ each; \$9 for 10.

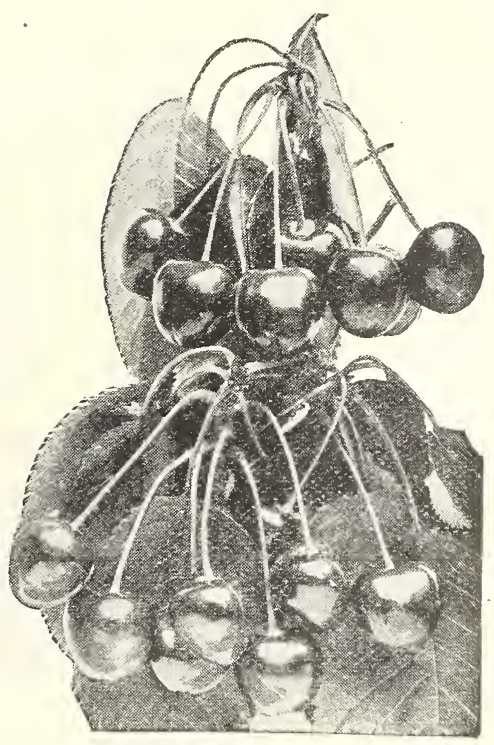




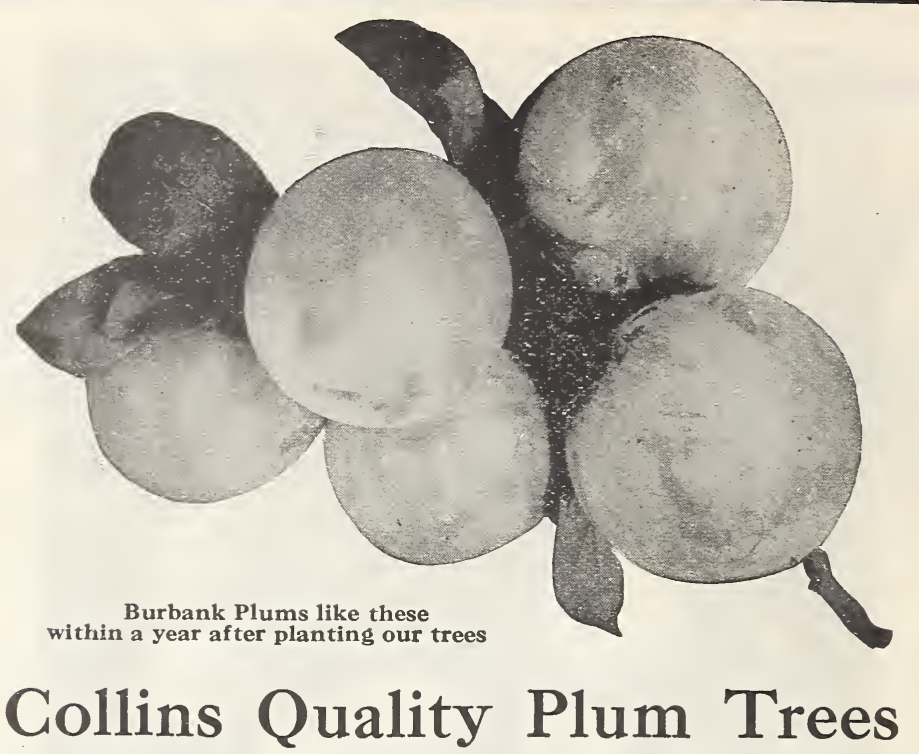

For several years the city markets have quickly absorbed the Plum crop; in fact there has not been enough fruit to meet the demand. The planting of Plum trees has been neglected, but the orchardists are now realizing their mistake, and the more prosperous ones are setting out Plum trees. The Japanese Plums are especially vigorous growers and begin bearing very soon after planting. The Japanese trees are always inclined to over-production and, if the small fruit is thinned, the remaining specimens will be increased in size and quality.

Commercial Planting. We suggest Abundance and Burbank as the two most satisfactory varieties. Plant 12 feet apart and 18 feet between the rows, making 201 to the acre. The best soil is a deep, loose, gravelly loam, with an open subsoil, such as is suited to potatoes, although any soil will do, provided it is well drained.

Garden Planting. The same varieties as named above will do best in the garden.

Three Plum Trees for \$3.20 f. o. b. Moorestown. (Regular price $\$ 3.75$.) Strong, vigorous, largest size trees, which will bear in year or two. Ideal for the home garden, one each of Abundance, Burbank and German Prune, a fine succession of choicest fruit.

ABUNDANCE. Yellow. (Japan.) Medium in size; color rich yellow with dots and splashes of red, and red cheek; flesh yellow, juicy and sweet: of good quality when well-ripened. Carries well to distant markets. Fruit should be thinned. Is in great demand.

BURBANK. Orange-yellow. (Japan.) Medium to rather large on thinned trees, roundish conical in form; orange-yellow, overlaid with red; flesh firm, meaty, yellow, rich, sugary. From two to four weeks later than Abundance. Exceedingly productive; one of the best of the Japans.

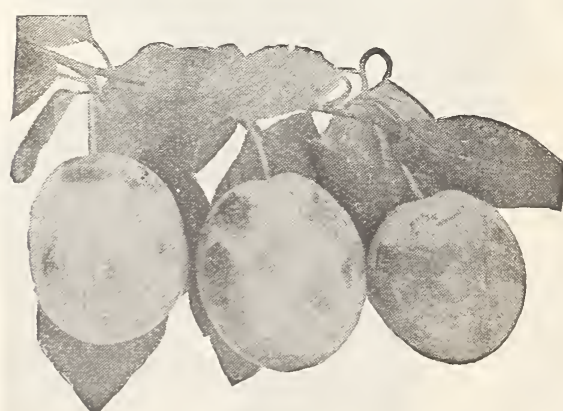

Abundance Plums

GERMAN PRUNE. Purple. (European.) Fruit oval in shape, nearly 2 inches long, of good quality; hangs well on the tree; is firm and sweet. A splendid preserving sort and excellent for dessert. Tree vigorous and very productive.

Lombard. Purple. (European.) Very productive; one of the best and most reliable for market. Color violet-red; medium size; juicy and good. Adheres to stone; flesh rich and tender. Hardy and adapted to light soils. 


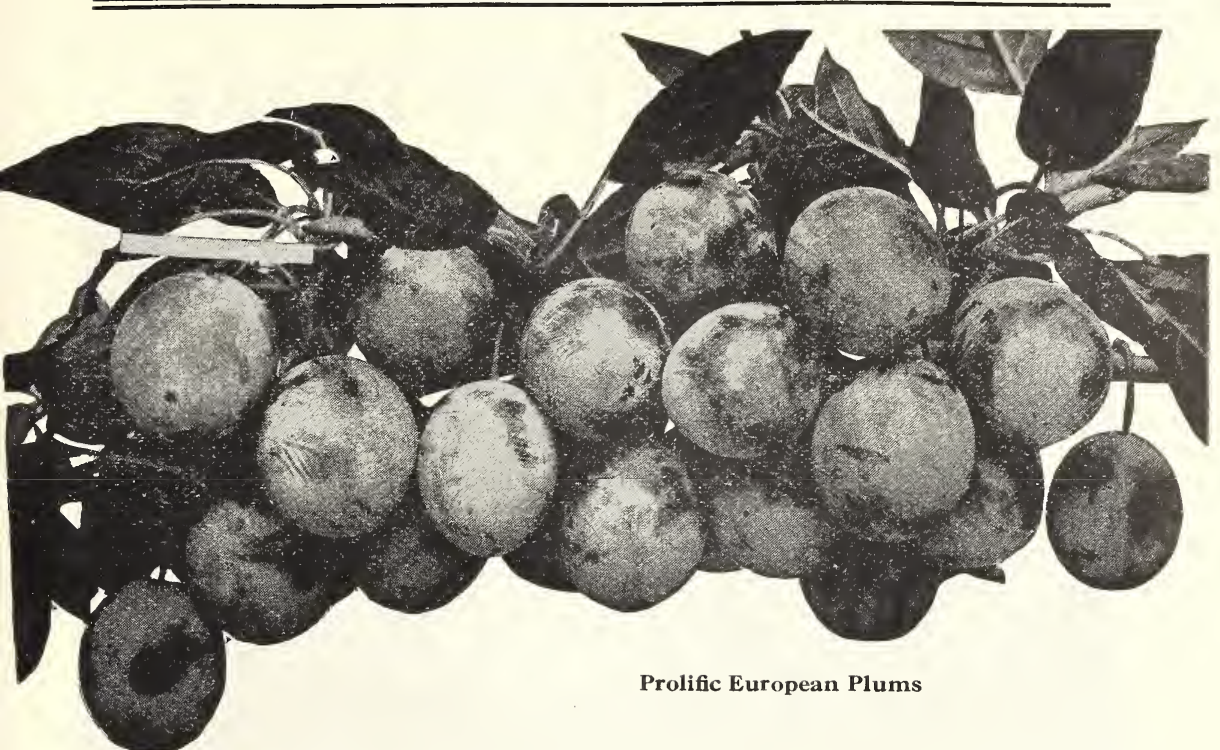

Red June. Red. (Japan.) Fruit is large, heart-shaped and slightly pointed, ripening early, just before Abundance. The flesh is light yellow, quite sweet and gives off a pleasant odor. Tree is a fast grower and not subject to disease.

Satsuma. Color, purple and red. Large globular, with a sharp point. The flesh is dark red, firm, juicy and of fine flavor. The pit is very small. Tree a hardy and vigorous grower. August.

Shippers' Pride. Purple. (European.) Large, nearly round; juicy and sweet. Splendid shipper; tree a moderate grower, but productive.

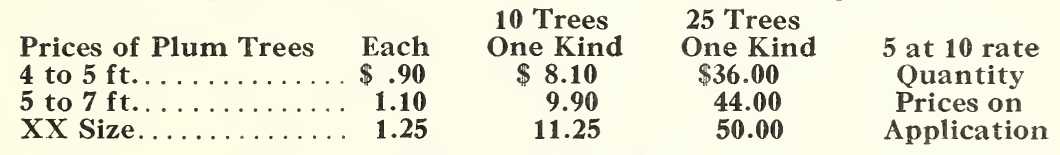

\section{MULBERRIES}

Mulberry trees are particularly desirable for shade on account of their rapid growth. Some people prize the fruit highly for pies. The fruit is used by many farmers for feeding to chickens, and a tree planted in the chickenyard is a valuable addition to it by reason of the dropping fruit.

Russian. Quite hardy and of rapid growth. Foliage is very handsome and the tree is decidedly ornamental. Fruit rather small. Bears very young. $\$ 1.25$ each; $\$ 10.00$ for 10 .

Dear Sirs: Our last order for two plum and two cherry trees has arrived safely and they are in beautiful condition. I planted them the day they arrived which was on May 4th, and they are looking fresh and healthy. The asparagus plants that I got from you last year are beginning to show up quite strong now.

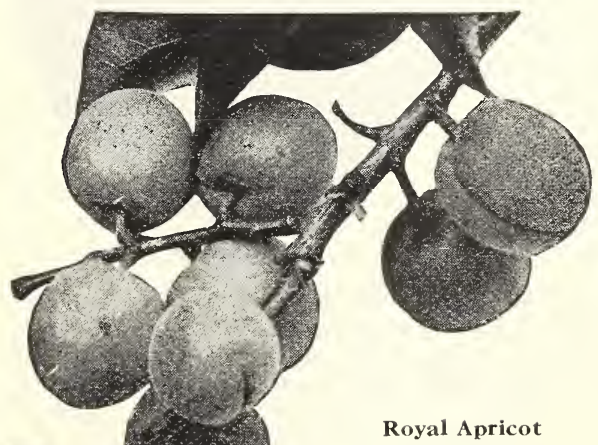

W. G., Portsmouth, N. H.

APRICOTS. The Apricot is a fruit somewhat intermediate between the peach and plum. The tree is a roundheaded, spreading grower, with dark, somewhat peach-like bark and very broad or almost circular leaves. The fruit, which generally ripens in advance of both the peach and the plum, is peach-like in shape and color, with smoother skin, rich yellow flesh, and large, flat stone. Commonly less juicy than the peach.

Early Golden. Small, pale orange, juicy and sweet. XX Trees only, \$1.25 each; \$11 for 10 .

Royal. Large, yellow, juicy, rich and delicious; a very fine variety. XX Trees only, $\$ 1.25$ each; $\$ 11$ for 10 . 


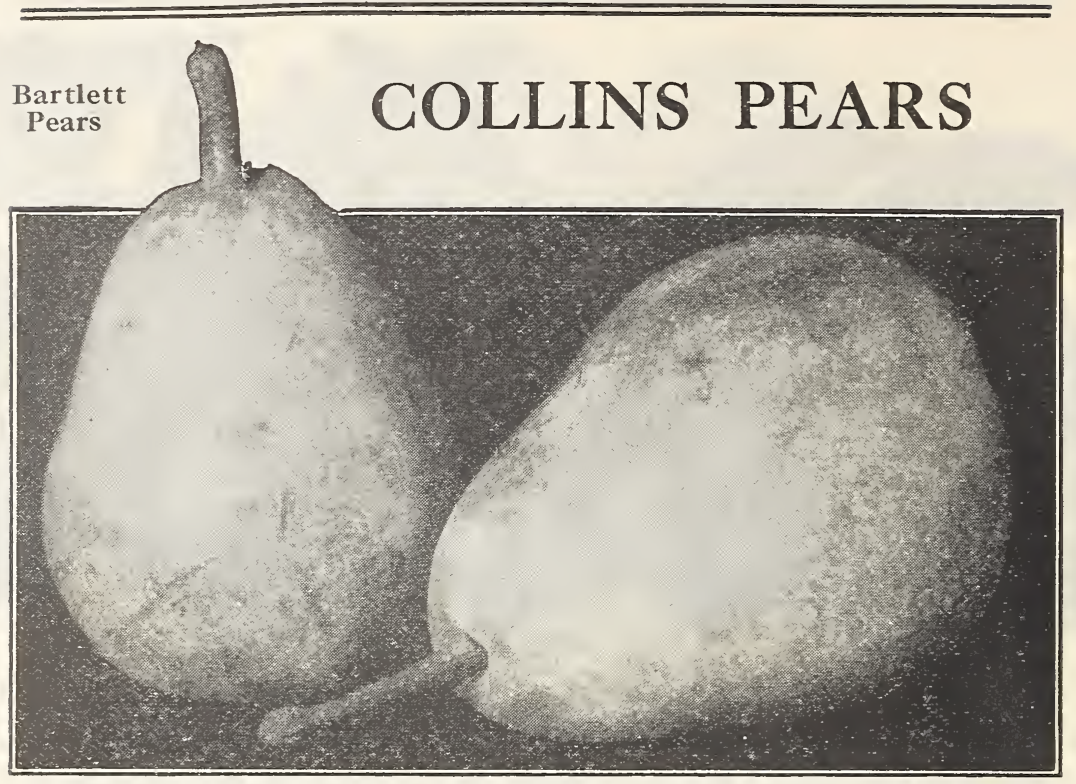

Good sweet, juicy Pears, easy to raise-easy to gather-this popular fruit should be in every garden. Collins quality Pear Trees have strong root systems and well-developed tops, and will therefore soon produce fruit. Our own pear orchards contain nearly 10,000 trees, $12 \times 16$ feet apart (225 per acre), of Kieffer, Bartlett, LeConte and Seckel. For the garden use Bartlett, Seckel, and Koonce.

BARTLETT. Large, yellow tinged with red, buttery and melting, with a rich flavor. Tree a vigorous grower, excellent for garden or commercial planting. The best canning pear. Bears abundantly and at about three years.

Beurre d'Anjou. Winter. Large, juicy, melting, and fine grain; a regular and vigorous annual bearer, eagerly sought in market.

Clapp's Favorite. Summer. Large and very showy, golden yellow with red cheek, quality good. Tree a good grower and very productive.

DUCHESS D'ANGOULEME. Autumn. Large, melting, juicy and well-flavored, greenish yellow; tree a good grower.

LECONTE. Autumn. Fruit large; skin smooth, pale yellow; quality medium. Trees besin to bear when quite young.

\section{Collins Pear Tree Offer. One Duchess, one Bartlett and one Seckel, three largest size trees in all, for $\$ 3.45 \mathrm{f}$. o. b Moorestown. Regular price \$4.50.}

KIEFFER. Winter. Tree remarkably vigorous and an early and very prolific bearer; one of the most profitable market pears. Much in demand by canners, exceedingly valuable for cooking and canning which bring out its best flavor. A beautiful yellow pear with bright red cheek; large size, quality medium. Tree bears at three years. 5-yr. size only, $\$ 2.50$ each.

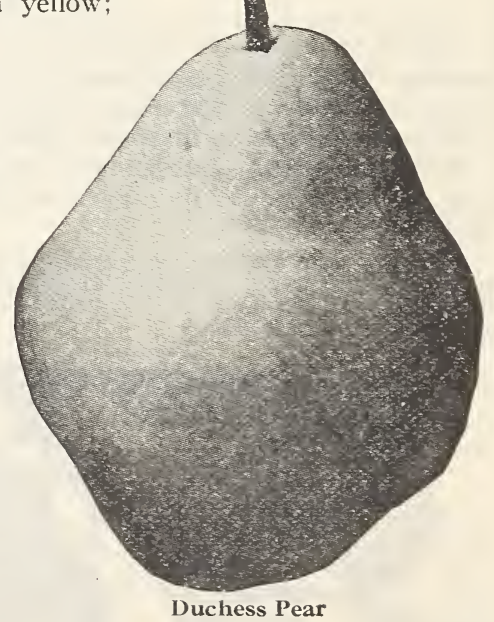

KOONCE. Early. Ripens its entire crop before the early harvest begins. Fine quality, large bright yellow, with crimson cheek; spicy, juicy and very sweet.

SECKEL. Late. Small, but of excellent flavor, fine for pickling and dessert. Very productive, yellow russet with delicious flavor, rich, melting, juicy, a general favorite.

Sheldon. Autumn. Large, round, yellow, a fine grower and productive.

Vermont Beauty. Summer. Hardy, resembles Seckel, larger and later.

$\begin{array}{ccccc}\text { Prices of Pear Trees } & \text { Each } & \text { On Trees } & 50 \text { Trees } & \\ 4-5 \mathrm{ft} . & \$ 1.00 & \$ 9.00 & \text { One Kind } & 5 \text { at } 10 \text { rate } \\ 5-6 \mathrm{ft} & 1.25 & 11.25 & 50.00 & \text { Ouantity } \\ \text { XX Size } & \mathbf{1 . 5 0} & 13.50 & \mathbf{6 0 . 0 0} & \text { Prices on } \\ \text { Application }\end{array}$


ARTHUR J. COLLINS \& SONS, INC.

\section{Collins Dwarf Trees}

Apple and Pear 'Trees at half size producing Full Size Fruit.

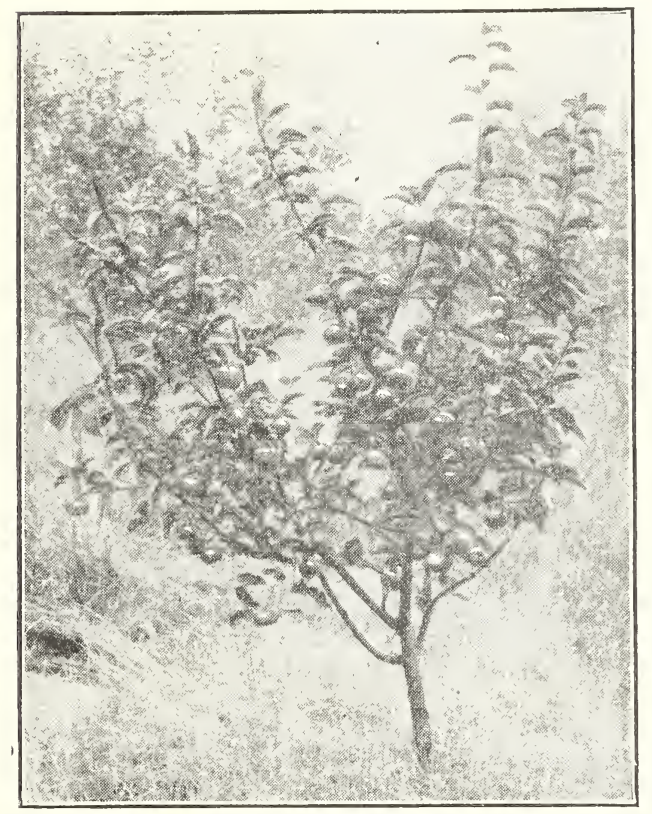

Dwarf Apole Tree

Collins Dwarf Apple Trees, just the thing for a small garden, because they are grafted on quince stock and always remain vigorous small trees. They are showy with their mass of bloom, and productive of much fine fruit, never growing to a great height. Plant 10 feet apart. We offer the following apples:

Wealthy, Delicious, Early Harvest, Baldwin, Stayman's Winesap and Yellow Transparent.

Dwarf Pears. If you wish a Pear orchard and have only a little space, and if you want it to bear early, plant dwarfs. These are grafted on quince stock and never grow large, bearing early and profusely.

Ideal as a screen; quite showy in the spring. The quality and size of fruit produced is equal to that of standard trees.

Plant them 10 feet apart. WVe offer the following:

Kieffer, Bartlett, Duchess, Clapp's Favorite and Seckel

Price of all of above Dwarf Trees $\$ 1.00$ each; $\$ 9$ for $10 ; \$ 40.00$ for 50 .

COLLINS SPEGIAL DWARF TREE OFFER

Seven dwarf fruit trees for $\$ 6.25$, f. o. b. Moorestown. Select any seven Dwarf Apple or Pear trees from above (no more than two of any one kind in your selection) or leave the selection to us and we will see that you have a proper succession of fine fruit.

\section{QUINCES}

The Quince is attracting a good deal of attention as a market fruit. The tree is hardy and compact and requires little space. It is productive, gives regular crops and comes into bearing early. The fruit is much sought for in canning. It will grow in any good garden soil, which should be kept mellow and well enriched. Fruit should be thinned out if it bears too freely.

Commercial Planting. Plant the trees 12 feet apart and 12 feet between the rows. This requires about 320 trees to the acre. Garden planting the same.

Champion. Hardy; prolific, bears young; fruit large, showy, yellow; delicious. Cooks as tender as an apple, and is one of the best keepers.

Orange. Large; golden yellow; good quality; profitable. Ripens late; keeps until February.

\begin{tabular}{|c|c|c|c|c|}
\hline PRICI & $\begin{array}{l}\text { E-LIST OF } \\
10 \text { Trees }\end{array}$ & $\begin{array}{c}\text { UINCE TR } \\
50 \text { Trees }\end{array}$ & EES & \\
\hline Each & One Kind & One Kind & 5 at 10 rate & \\
\hline 3 to $4 \mathrm{ft} . \$ 1.25$ & $\$ 11.25$ & $\$ 50.00$ & Quantity & \\
\hline 4 to $5 \mathrm{ft} .1 .50$ & 13.50 & 60.00 & Prices on & Ouitrce \\
\hline XX Size. .1.75 & 15.75 & 70.00 & Application & \\
\hline
\end{tabular}

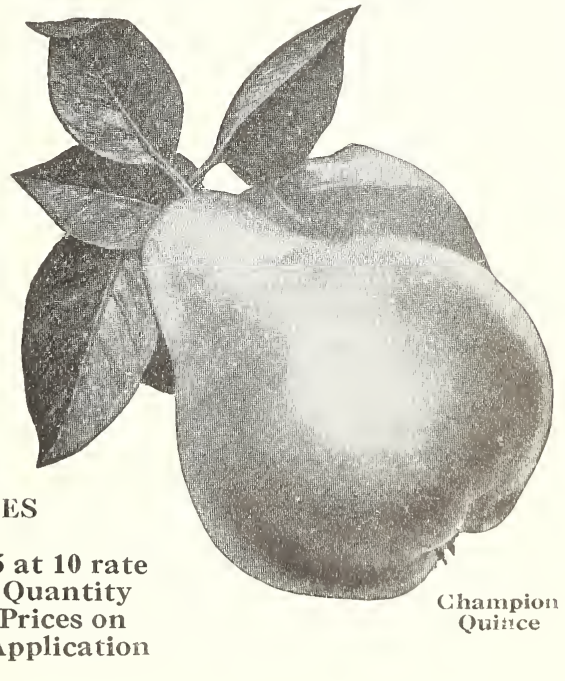




\section{COLLINS BUDDED AND GRAFTED NUT TREES}
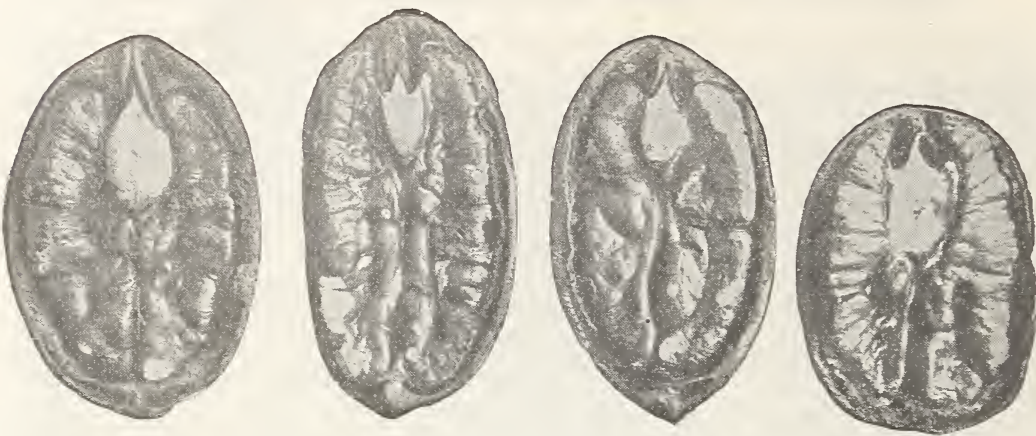

Picture showing kernels of Pecan Nuts grown in northern States

Because Nuts are very rich and have a high protein and fat content they are the most concentrated natural food known. In the Nursery, just as it is necessary to bud and graft fruit trees from the seedlings, so must nut trees be grafted and budded from seedlings to produce nuts yearly and true to type. A short piece of live wood remored from the thrifty, bearing Mother-trees, is grafted or budded on new young stock.

So we can now offer you trees that will actually bear good nuts and in quantity. The trees are hardy and are not affected by our winters. It is not uncommon for Pecans to bear the fourth year, Walnuts the third, and Filberts the second year.

\section{NUT TREES ARE JUST AS SURE AS FRUIT TREES TO BEAR.}

Nut trees are ornamental, why not plant them on your lawn? They make good shade and produce a bountiful supply of wholesome nuts as well.

It is almost useless to buy Nut Trees that are not grafted. They are cheaper to buy, but they seldom bear any nuts at all. Buy Collins Grafted and Budded Nut Trees, and be sure of rich, sweet nut kernels.

PECAN. Busseron. From Indiana. One of the best Pecans and one of the most reliable. Nut large and long. The original tree in Indiana has a fine record of bearing. Kernel plump and of fine grain. $\$ 3$ each, 10 for $\$ 27$.

SPANISH CHESTNUT. Nut quite plump and excellent for roasting being deliciously sweet and tender. Blight resistant, bears young and very abundantly. \$2.50 each.

BLACK WALNUT. Thomas. Very hardy and rugged variety. Large kernel of very fine quality. $\$ 3.50$ each, 10 for $\$ 32.50$.

FILBERT. English. The best Hazelnut, hardy and thrifty even if entirely neglected. Nut large and oblong. Kernel plump and of rich quality. Tery productive. $\$ 2.00$ each, 10 for $\$ 17.50$.

HICKORY. Kernel sweet and delicious, tree vigorous and grows into a beautiful specimen. $\$ 3.50$ each, 10 for $\$ 32.50$.

ENGLISH WALNUT. Our sturdy English Nalnut trees are budded and grafted on the native black walnut stock, hence they ripen their wood earlier and more thoroughly than the seedling trees do, and are therefore hardier than the ordinary seedling tree frequently offered for sale.

Franquette. This is the finest Eastern variety of English Walnut. The tree is a rapid grower and ail early bearer. The nuts are large, smooth and attractive. The kernel is plump and of excellent quality. $\$ 3.25$ each, 10 for $\$ 30$.

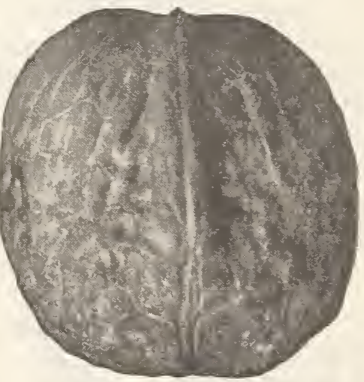

English Walnut 


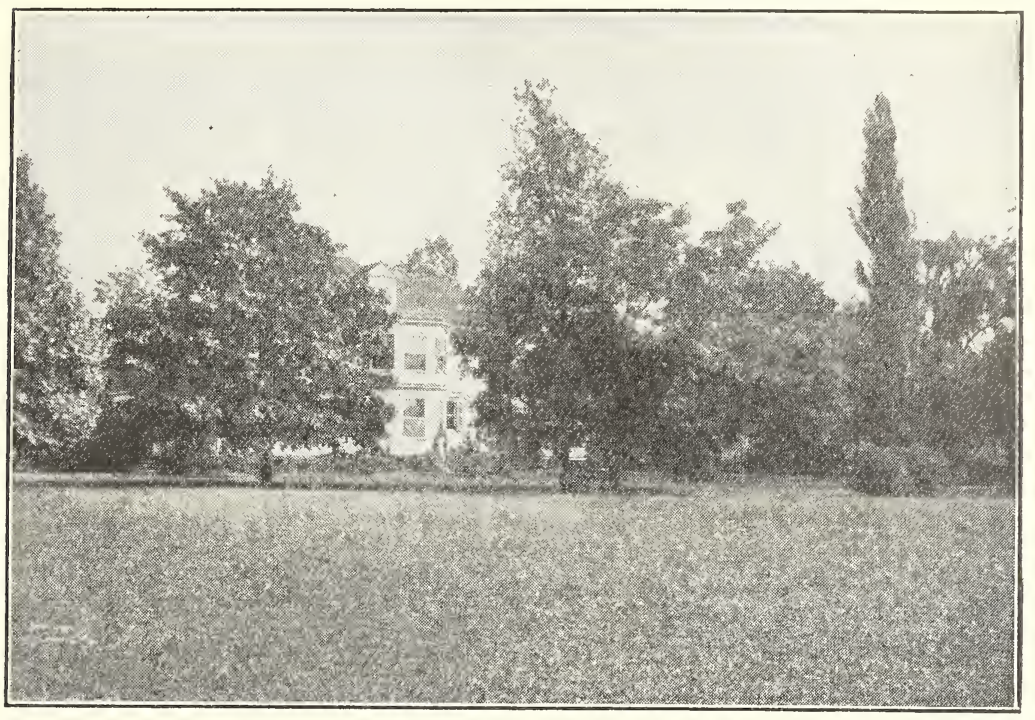

\section{Collins Blended Lawn Grass Seed}

(Sow 1 quart on a plot $10 \times 10$ feet or 100 square feet; 4 quarts on 600 square feet; one peck on 1500 and 1 bushel on 7000 square feet. Sow 6 to 8 bushels per acre to give a thick sod from the start.)

(Occasional applications of Sheep Manure through the growing months give color and strength to the new lawn, see page 65.)

999. Collins Velvet Lawn. With this very carefully selected blend of Lawn Grasses we equip you with an ideal mixture to build a fine lawn. Every variety of Grass in it has its special use. There are deep-rooted varieties, spreading ones, tall-growing and dwarf varieties, also those with a rich bright green color, and fine blades. All the kinds unite to form a fine thick turf of velvety texture, which we unqualifiedly recommend. Postpaid, 1 quart 40c. By express 1 quart 35 c; 2 quarts 65 c; 4 quarts $\$ 1.25$; peck $\$ 2.25 ; 1$ bushel (20 lbs.) $\$ 8.00 ; 100$ pounds or more $37 \frac{1}{2} \mathrm{c}$ per pound.

1000. Collins Evergreen Lawn Grass. This is an excellent mixture for new ground and for renovating old Lawns. It consists of a carefully blended combination of the best short-growing, fine-bladed grasses, selected from foreign and native stocks. It will produce a permanent sod in a few weeks. It contains a small amount of White Dutch Clover which adds greatly to the appearance of the turf. Blended from varieties that are deep-rooted and best adapted to the various climatic conditions of America. Postpaid, 1 quart 35c. By express or freight, 1 quart $30 \mathrm{c}$; 2 quarts $55 \mathrm{c} ; 4$ quarts $\$ 1.00 ; 1$ peck $\$ 1.75 ; 1$ bushel $(20$ pounds) $\$ 6.50 ; 100$ pounds or more $30 \mathrm{c}$ per pound.

1001. Collins Shady Lawn Grass. This contains a proper blending of varieties of grasses that grow well in shady places. This mixture of seeds produces perfect swards in most densely shaded places where other seeds fail. Postpaid, 1 quart $40 \mathrm{c}$. By express or freight, 1 quart $35 \mathrm{c} ; 2$ quarts $65 \mathrm{c} ; 4$ quarts $\$ 1.25 ; 1$ peck $\$ 2.25 ; 1$ bushel (20 lbs.) $\$ 8.00 ; 100$ pounds or more $371 / 2 \mathrm{c}$ per pound.

1002. Collins Seashore Lawn Grass. This mixture is composed of those varieties of grass that will thrive in salt air regions, producing a good sod in a few weeks, even at the shore. Postpaid, 1 quart 40c. By express or freight, 1 quart $35 \mathrm{c} ; 2$ quarts $65 \mathrm{c} ; 4$ quarts $\$ 1.25 ; 1$ peck $\$ 2.25 ; 1$ bushel (20 lbs.) $\$ 8.00$; 100 pounds or more $371 / 2 \mathrm{c}$ per pound.

Clover, Collins Fancy White. $\$ 1.10$ per lb. postpaid.

\section{SOW COLLINS LAWN GRASS SEED AND HAVE A LUXURIANT GREEN T'URF.}




\section{Aids to the Rose Fancier}

E. M. Rosenbluth, famous rose-fancier of Wallingford, Pa. created the formula for these three preparations, solving three important problems which the rose grower sometimes meets. All have advantages as fertilizers as well as fungicides.
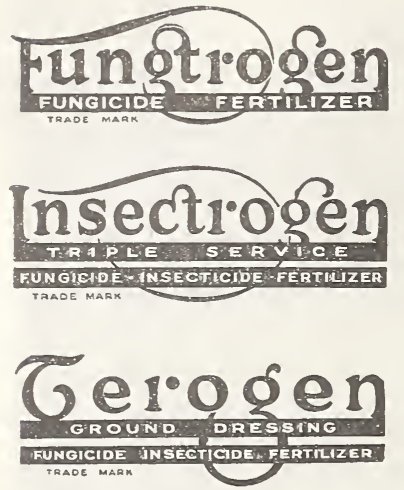

Fungtrogen-The fungicide which conquers mildew practically over night and controls black spot. An effective plant stimulant alsoproviding nitrogen in a manner which assures luxuriant foliage and healthy plants. Pint \$1.40 P; Quart \$2.35 P; Gallon \$6.00 E.

Insectrogen-Combats leaf-chewing insects, including the Japanese Beetle; and Black Spot on roses. Fertilizes through the leaf. Half pint $\$ 1.00 \mathrm{P}$; Pint $\$ 2.00$ P; Quart $\$ 3.25$ P; Gallon $\$ 8.00$ E.

Terogen-Destroys spores of fungus, kills insect larva and eggs, acts as fertilizer. Applied through the soil; prevents the yellowing of foliage and weakening of bushes. $1 \mathrm{lb} .90 \mathrm{cts}$. P; 2 lbs. $\$ 1.50$ P; 10 lbs. $\$ 5.25$ P.

Nikoteen. Used by successful rose growers and other florists for fumigation of their greenhouses, it is invaluable also for outdoor spraying to control the Aphis (or Plant louse) Roseleaf Hopper, Grapevine Leaf Hopper and Apple and Peach Aphis, etc. Used as a spray, only one part Nikoteen is required to 500 parts of water, therefore it is most economical in use. Per 2 oz. bottle $50 \mathrm{cts}$.; $1 / 2 \mathrm{lb}$. $\$ 1.50$.

Hyper Humus. This is organic matter consisting of partially decomposed vegetable plants, and is a very valuable food for truck and flower gardens as well as lawns, shrubbery and trees. Very similar to leaf mould, though more concentrated and is very black and granular. This Hyper Humus renders clay soils lighter, and sandy soils better able to retain moisture. It is the source of nitrogen and sets free for plant growth many otherwise insoluble mineral elements in the soil. Fine for Perennials, Roses, Dahlias, Vegetables and Lawns, etc. By express 50 lbs. $\$ 1.35 ; 100$ lbs. $\$ 2.25 ; 500$ lbs. $\$ 10 ; 1000$ lbs. $\$ 15$; per ton $\$ 25$. Special prices by carload lots.

Oyama. A wonderful Japanese plant food, used as powder or liquid. Clean, odorless, efficient-makes plants, flowers and vegetables thrive. Highly concentrated, no bone, soda, lime or manure. Guaranteed analysis (by Cornell University), Nitrogen $17 \%$; available Phosphoric Acid $17.35 \%$; Potash $24.52 \%$. House plant size 35 cts. $\mathbf{P}$; garden size \$1.25 P.

\section{Collins Collected Wood Ashes}

\section{A Superior Stimulant for Roses, Dahlias, etc.}

These Pure Wood Ashes are collected from our own fires where our orchard stumps, limbs and trimmings are burned. Made up of apple, cherry and pear wood these clear ashes give to soils a fine lot of readily available potash for the plants. No crop can grow without potash. With it you can count on a full crop of fruit or flowers, without it the growth will be "scrubby." Potash of wood ashes is very caustic, and as such is very active in decomposing vegetable matter and acting beneficially on the mechanical condition of the soil, which in part accounts for its astonishing effect on plant growth. Spread 1000 lbs. per acre.

Indispensable for all crops and especially beneficial to Roses and Dahlias. 5 lbs. $60 \mathrm{cts}$. postpaid, up to and including 4 th postal zone. By express 50 lbs. $\$ 2.00$; per bag (100 lbs. approx.) $\$ 3.00 ; 500$ lbs. $\$ 12$; per ton $\$ 40$.

\section{Collins Improved Metal Labels}

Made of copper alloy - endure because metal is unaffected by weather conditions. So constructed that wire cannot cut through the tag.

Identify vines, bushes, shrubs, trees, etc.-record date of planting-by using these easily marked tags. To inscribe your record, place tag on folded newspaper, write with stylus or hard pencil, bearing hard to indent metal.

No. 1 size - most desirable for trees, etc.-measures $3 / 4$ in. wide by $3 \frac{1}{2}$ in. long. 5 cts. each $\mathbf{P}$; 50 cts. per doz. $\mathbf{P}$; $\$ 3$ per box of $100 \mathbf{P}$; in which one all steel stylus is included free. All labels have enduring fastening wire attached.

P means by Parcel Post, Prepaid (West of Miss. R. add 10\%). E means by Express, see page 67. 


\section{Collins Highest-Grade Fertilizers}

Collins Sheep's Head Sheep Manure, Pulverized. "A whole wagon load of rich manure compressed into a bag." This is a splendid, concentrated manure taken from covered pens where sheep are fattened on grain and is then dried, ground to an even fineness, and packed in bags for convenient use. This drying process kills all the lurking weed seeds, making it an exceedingly pure manure and clean to handle. It is exceedingly rich in nitrogen, phosphoric acid and potash, three very essential, enriching ingredients for any soil, and very important to the growing plants. Use it freely on your evergreen bed and on flower beds and for roses. No plants will grow without plant food, and whether the soil is rich or poor, it should have a generous application of this manure if strong, healthy plant life is expected. Easy to handle, clean and efficient; on lawns use ten pounds to each one hundred square feet. Price per $10 \mathrm{lb}$. trial bag, $75 \mathrm{cts}$., postpaid up to and including 4th postal zone; $100 \mathrm{lb}$. bag, $\$ 3.50$, express or freight.

Collins Bone Meal. Made of pure, raw bone without any addition of outside materials. This is an ideal fertilizer for rose beds and for greenhouse work. Use this fertilizer for all purposes; safe and effective. $10 \mathrm{lbs}$, 60 cts.; 25 lbs., \$1.40; 50 lbs., \$2.50.

Collins Pleasant Valley Plant Food. A lover of roses and plants who lives in Moorestown has always had such marvelous flower gardens and such a beautiful lawn that we were convinced he was getting his results from some secret method. We investigated and found he used a fertilizer or plant food discovered by himself which was working wonders for indoor plants, evergreens, roses, lawns, etc. It makes plants much greener and healthier, and the bright flowers last longer when cut. It contains $3 \%$ potash, $6.7 \%$ phosphoric acid and $21 / 2 \%$ nitrogen. It drives ants and earth worms away too. He will not disclose the formula, but we have finally induced him to make his product in larger quantities in order to supply our customers. Therefore, we can now offer his wonderful Plant Food which we can heartily recommend. Use this freely and have more beautiful flowers. $1 \mathrm{lb}$. carton, 35 cts. postpaid; 4 -lb. carton, $\$ 1.00$ by express; 10 -lb. carton, $\$ 2.25$ by express.

Collins Garden Loam. Excellent, rich garden earth secured from wellfertilized plots, put up in sacks containing 2 to 3 bushels: extensively used at seashore points. Price per sack, $\$ 1.00$ by express; special price on larger quantities or by truck-load.

\section{COLLINS LIST OF HELPFUL BOOKS BY MAIL POSTPAID}

Carefully selected books each of which is most helpful and instructive in the subject with which it deals. The authors are authorities on their subjects; all are well illustrated.

Asparagus. By F. M. Hexamer. Cloth, $90 \mathrm{cts}$.

Dwarf Fruit Trees. By F. A. Waugh. Cloth, 90 cts.

Landscape Gardening. By F. A. Waugh. Cloth, \$1.25.

The Home Vegetable Garden. By Adolph Kruhm. Cloth, \$1.50.

The New Rhubarb Culture. By J. E. Morse. Illustrated. Cloth, 90 cts.

The American Peach Orchard. By F. A. Waugh. Cloth, \$1.75.

The American Apple Orchard. By F. A. Waugh. Cloth, \$1.75.

Beginner's Guide to Fruit Growing. By F. A. Waugh. Cloth, \$1.25.

Plums and Plum Culture. By Prof. F. A. Waugh. Cloth, \$2.50.

The Fruit Garden. By P. Barry. Cloth, $\$ 2.25$.

The Nut Culturist. By Andrew S. Fuller. Cloth, \$2.00.

American Grape Growing and Wine Making. By George Husmann. Illustrated. Cloth, \$2.00.

Small Fruit Gulturist. By Andrew S. Fuller. Illustrated. Cloth, $\$ 1.60$. Gider Maker's Handbook. By J. M. Trowbridge. Illustrated. Cloth, \$.1.40. Strawberry Culturist. By Andrew S. Fuller. Illustrated. Cloth, $40 \mathrm{cts}$.

The Window Flower Garden. By Julius J. Heinrich. Cloth, 90 cts.

The Ghrysanthemum. By A. Herrington. Illustrated. Cloth, 90 cts.

Principles and Practice of Pruning. By M. G. Kains. Cloth, $\$ 2.50$.

American Fruit Culturist. By J. J. Thomas. $\$ 3.50$.

How to Grow Roses. By Robert Pyle. Illustrated. Cloth, \$2.00.

The Practical Flower Garden. By H. R. Ely. Color. \$2.50. 


\section{Plant Grape Vines NO W}

Pick your own fresh grapes-for grape juice, jelly or table use-right from your own vines. Even the smallest property has room for 4 grape vines-use your fence or the side of the house. Collins Grape Vines are grown to bear great crops. We send them out ready to work for you.

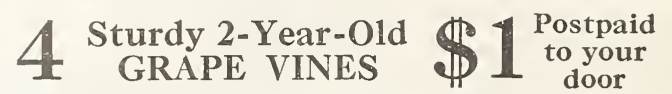

Will bear the first year

Your selection of any of these leading varieties, choose four vines:

Concord (blue) Niagara (white) Catawba (red)

Prices of larger quantities, by express; see pages 48 and 49 .

\section{Pick Finest Fresh Fruit From Your Own Trees!}

\section{Excellent Young $\$ 1$
Apple Trees
$\mathbf{1}$ Postpaid}

Fine succession fruit at all seasons.

Early Harvest. Very early, yellow, juicy, tender.

Wealthy. Splendid eating and cooking, juicy, large, crisp.

Grimes Golden. Highly-flavored, crisp, finest to cook and to eat.

Delicious. Red, sweet, good keeper, wonderful eating.

Stayman's Winesap. Fine flavor, juicy, good keeper, cooking or eating.

We send you real value. COLLINS thrifty, clean apple trees, well-rooted, quickly develop into bearing trees. Start your garden now-benefit for years to come.

\section{$5 \begin{aligned} & \text { Collins Young } \$ 1 \\ & \text { Peach Trees } \\ & \mathbf{1}\end{aligned}$ Postpaid} Finest succession of Peaches all summer and fall.

Early Crawford. Yellow, early, sweet, fine-flavor, freestone.

Belle of Georgia. Second-early, white, very sweet, freestone.

Hale. Sweet, large, yellow, fineflavor, bears abundantly.

Elberta. Popular favorite for canning, yellow, freestone.

Crawford's Late. Fine flavor, large, yellow, freestone.

In this exceptional collection you get sturdy, well-grown COLLINS trees, with plenty of roots, which quickly develop into bearing trees. A fine foundation for your fruit garden.

Collins Berry Collection
No. A-101 Postpaid, $\$ 1.85$
2 Value $\$ 2.20$
2 Cherry Currants.
2 Downing Gooseberries.
2 Gregg Raspberries.
2 St. Regis Raspberries.
2 Eldorado Blackberries.
2 Ward Blackberries.

\section{Collins Root Crop Offer}

No. A-107 Value \$2.35.

Postpaid, $\$ 1.95$

4 Victoria Rhubarb Roots.

50 Palmetto Asparagus Roots, 2-yr.

4 Horse-Radish Sets.

\section{Collins Jelly and Jam Collection}

No. A-105

Postpaid, $\$ 2.95$

Value \$3.63.

1 Concord Grape.

1 Niagara Grape.

1 Catawba Grape.

2 Fays Prolific Currants.

2 Downing Gooseberries.

3 Cuthbert Raspberries.

3 St. Regis Raspberries.

3 Ward Blackberries.

4 Victoria Rhubarb.

\section{Collins Famous Fruit-Tree Offer}

Carefully selected, largest size; Value $\$ 13.75$. Price, $\$ 8.75$ by express.

1 Yellow Transparent Apple.

1 Wealthy Apple.

1 Grimes Golden Apple.

1 Bartlett Pear.

1 Seckel Pear.

1 Montmorency Cherry.

1 Windsor Cherry.

1 Carman Peach.

1 Belle of Georgia Peach.

1 Elberta Peach.

1 Champion Quince. 1 Burbank Plum.

Famous Fruit Tree Offer Pleases by Growth

I am well pleased with the 12 trees sent me last fall. Every tree and plant, purchased from you, is doing fine and I am looking forward to receiving the enclosed order.

C. H. D., Pensauken, N. J. 
I N D E X

\begin{tabular}{|c|c|c|}
\hline Page & Page & Page \\
\hline Apples.... . .52, 53, 66 & Dwarf Pears......661 & Peonies... . . . . . . . 15 \\
\hline Apricots.........559 & Evergreens . . . . 30-33 & Perennials. . . . . .9-18 \\
\hline Asparagus......50,51 & Rear Cover & Phlox...........15 \\
\hline Azalea...........32 & Fertilizers.....64, 65 & Pinks.......... 12 \\
\hline Barberry . . . . . . . 29 & Forsythia........20 & Plums........58, 59 \\
\hline Berry Collection.... .66 & Fruit Tree Offer. . . .66 & Рорру............ 14 \\
\hline Blackberries.......446 & Fungicides ........64 & Privet..........28 \\
\hline Bleeding Heart. . . . . 12 & Grapes.....48, 49, 66 & Quinces..........61 \\
\hline Books on Gardening. . 65 & Grass Seed.......63 & Raspberries.... .44,45 \\
\hline Boxwood . . . . . . . 32 & Hydrangea........21 & Root Crop Offer. . . .66 66 \\
\hline es......56,57 & Iris . . . . . . . 14 & Rose Aids.... . . . . 64 \\
\hline Christmas Tree......33 & Jelly and Jam Col- & Roses-Covers . . . . 1-7 \\
\hline Chrysanthemums. 10, 11 & lection.........66 & Shade Trees... . 38, 39 \\
\hline ers........ 8 & Labels... . . . . . . . 64 & Shasta Daisy ....... 11 \\
\hline t. . . 34, 35, 68 & Lilac. . . . . . . . . 221 & Shrubs. . . . . . . . 19-23 \\
\hline Currants........47 & Lily of the Valley.... 12 & Spirea...........22 \\
\hline Dahlias . . . . . 24-27 & Mock Orange. . . . . . 22 & Strawberries . . . .40-43 \\
\hline Delphinium.......11 & Mulberries... . . . . .59 & Sweet Williams. . . . . 12 \\
\hline Deutzia.........20 & Nut Trees. . . . . . . 62 & Vines.......... 8 \\
\hline Dogwood Tree......38 & Peaches.....54, 55, 66 & \\
\hline Dwarf Apples.....661 & Pears...........60 & \\
\hline
\end{tabular}

\section{Terms, Conditions of Sale, Etc.}

The prices contained in this catalogue abrogate all other prices that have been previously published or quoted, and, except where noted, 5 will be sold at the 10 rate, 50 at the 100 rate, 500 at the 1,000 rate.

Terms Cash. Our terms are cash with order. As an inducement to send cash, we give you the benefit of the low prices named in this catalogue. Remittances may be made by Post-Cffice Order on Moorestown, N. J., or by Check or Draft on New York or Philadelphia, made payable to our order, or by Registered Letter.

Symbol $\mathbf{P}$, following the price of an article means this item will be sent by Parcel Post, all charges paid by us (as far west as Mississippi River). Beyond that point $10 \%$ is to be added for parcel post delivery, unless otherwise specified.

Symbol $\boldsymbol{E}$ indicates item is too heavy or large for parcel post and must go by Express, purchaser paying transportation charges only on arrival. We reserve the right to include Parcel Post articles in Express packages, giving extra plants for postage, to expedite shipments.

Substitution. It is our custom, should the supply of a variety be exhausted, to substitute in its place another, similar or better, correctly labeled. If it is desired that" we shall not do this, affix to the order the words "no substitute."

Guarantee and Conditions of Sales. Purchasers are hereby notified that although we shall continue to take all possible care to supply good, healthy, thrifty trees, shrubs and plants true to name, and hold ourselves in readiness to replace, on proper proof, all stock that may prove untrue to name or refund the amount paid, we do not give any other warranty, express or implied, with respect to the goods we send out, and shall in no way be responsible for other defects or loss of crops. Every order received for articles named in this catalogue will be received and executed on the above conditions only, and with the distinct understanding and agreement on the part of the purchaser that we shall in no case be liable for a greater amount than the sum originally paid to us for the stock in question. Claims, if any, must be made upon receipt of goods, or they will not be allowed. 


\section{Grand Prizes for a Name}

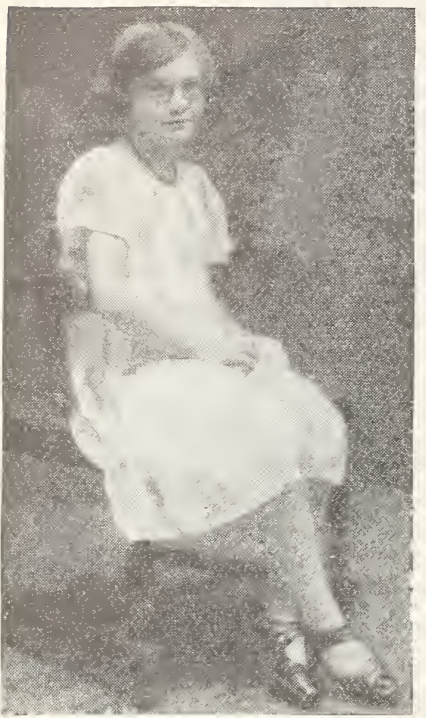

Dorothy Klein, Harborcreek, Pa., winner of our 1925 Contest.

\section{Harborcreek, Pa.}

I want to thank you for the check you sent me for my cross-word puzzle. I was very much pleased to get it get it and $I$ put it in the bank at erie. I waited to taken to send you

Yours very truly,

DOROTHY KLEIN.

\section{COLLINS "BEST EVER" \\ LANDSCAPE COLLECTION (see page \\ 31 ); or other goods to amount of . . . $\$ 24.75$ \\ Second Prize: \\ COLLINS "PERENNIAL PLEASURE" BORDER}

First Prize:

(See page 18); or other goods to amount of $\$ 11.75$

\section{Third Prize:}

\section{COLLINS FLOWERING SHRUB OFFER}

(See page 23); or other goods to a mount of . $\$ 7.50$

To those submitting the 15 next best titles we will send one of our famous Faultless Five Rose Collections (as described on page 1 ) or any other $\$ 1.95$ Collection described in this catalog.

To the next hundred contestants we will give a tiny barberry plant (see page 29), which will develop into a fine specimentherefore allow room for growth.

Send in as many titles as you like-only one prize to any one contestant. You do not have to make a purchase to enter the contest. We will gladly send any interested person a copy of this 1926 Guide FREE. There is only one condition-Contest closes midnight July 1, 1926. All prizes will be mailed as soon thereafter as planting is desirable.

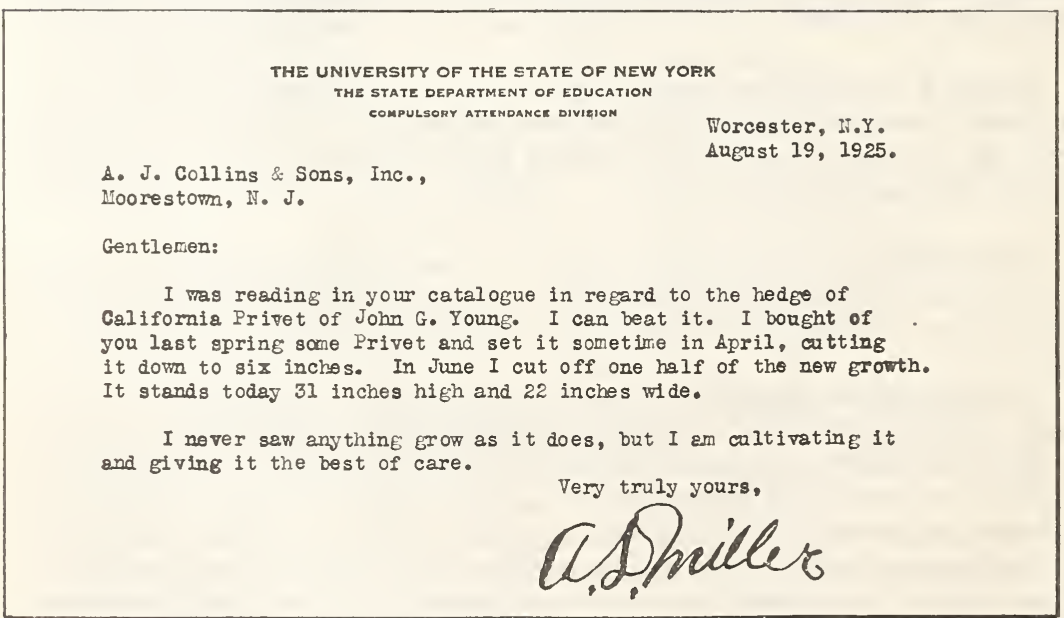

The letters of commendation in this book-and the thousands of others in our files-were unsolicited. In some cases customers have sent photographs of their flowers, etc., which we greatly appreciate. It helps visualize the story. 


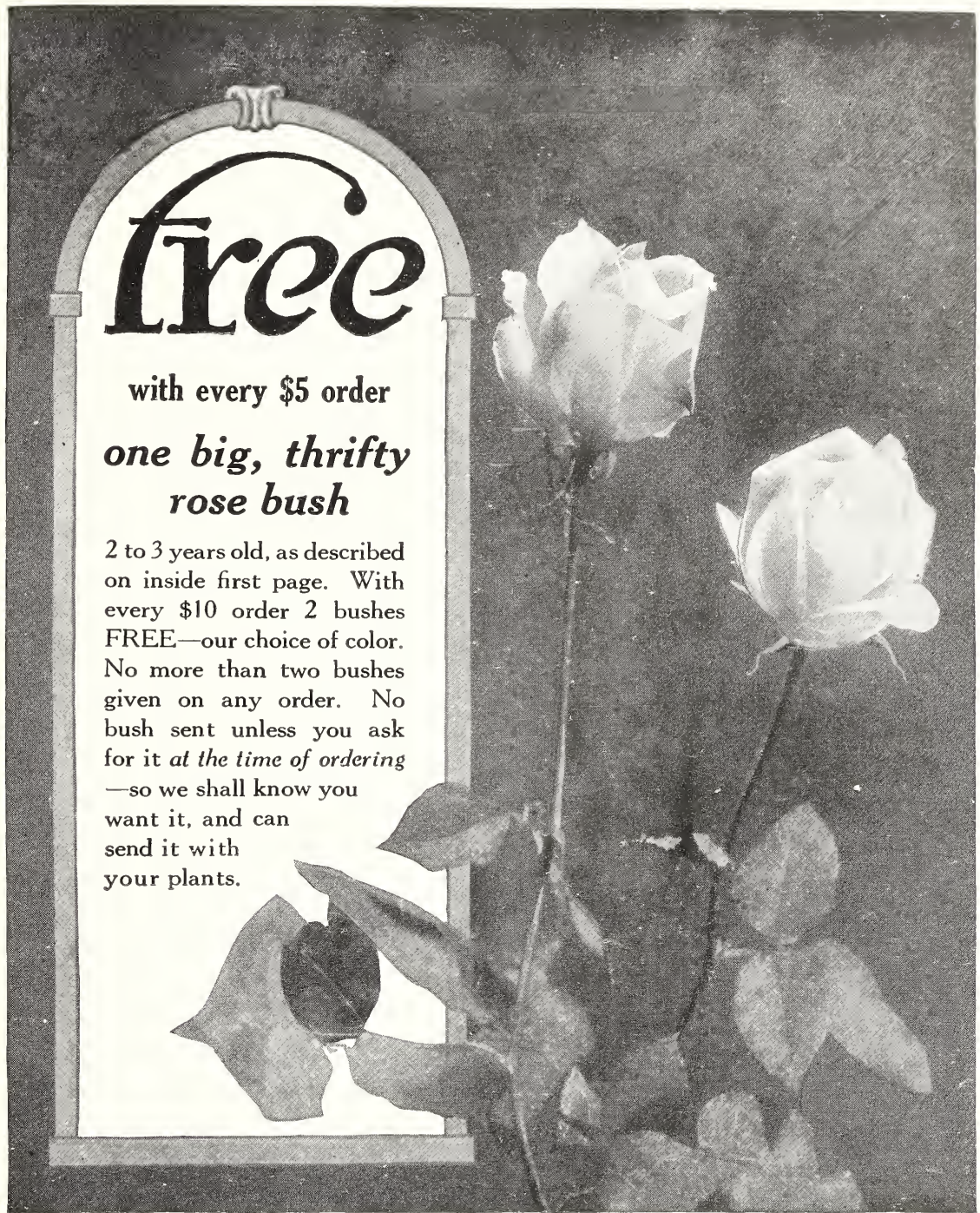

\section{Collins "Faultless Five" Roses making friends all over America-and down to the Canal Zone}

Received iny five rose bushes in good condition and was more than pleased. I received them on Wednesday, put them in water for a day, then planted them. After two days the Columbia bush had a bud on it. My neighbors were as pleased as I was, and one has sent for five. Will red as I was, and one has sent

Mrs. J. I. E., Pedro Miguel, Canal Zone.

The rose I received from you with an order of $\$ 5.00$ had 28 bloom

H. MacV., Phila, Pa.

The Faultless Five roses I got from you 2 years ago are the finest I ever saw, and are constant bloomers year after year

$$
\text { Mrs. D. E. DeM. Aspen, Col. }
$$

Gentlemen:

January 4, 1926

Enclosed please find my check for $\$ 3.90$ for which kindly send us two of your collections. We enjoyed your roses so much last year and found them to be all you advertised. It was a wonder they did anything as they were sent to the apartment and we had to keep them until we came up the following week-end. The Ophelia which you gave as a premium with the trees, etc, had buds until frozen.

Mrs. L. G. B. Golden's Bridge, New York.
Gentlemen :

Sept. 9, 1925

I want to tell you how delighted I have been with my five rose bushes which I crdered from you this spring. All of them have lived and bloomed beautifully and am anxious to duplicate the order again next spring.

$$
\text { D. M. W., Granville, Ohio. }
$$

GENTLEMEN:

January 5, 1926. "Enclosed find check to cover your five rose bushes for $\$ 1.95$. We bought one of these colections last year and the bushes are worth al we paid for them. They might have forgotten to stop blooming after the first year but not these good roses. They went right to blooming this year. Please send us another collection. H. D. C., Ozark, Ala.

DEAR SIRS: Sept. 26, 1925

I purchased your "Faultless Five" last spring and recommended them to all my friends. They have bloomed profusely all summer and I consider they were worth more than I paid for them. J. F. D., Baltimore, Md.

Gentlemen: Aug. 3, 1925

My five roses are all in bloom and being very proud of them am telling and showing all my priends. I. T. Vinsted, Conn

These few testimonials, among thousands in our files, have been voluntarily sent in to us by enthusiastic customers, many of them along with re-orders. The center pases show how large this business has grown, because of the satisfaction our plants give our customers. 


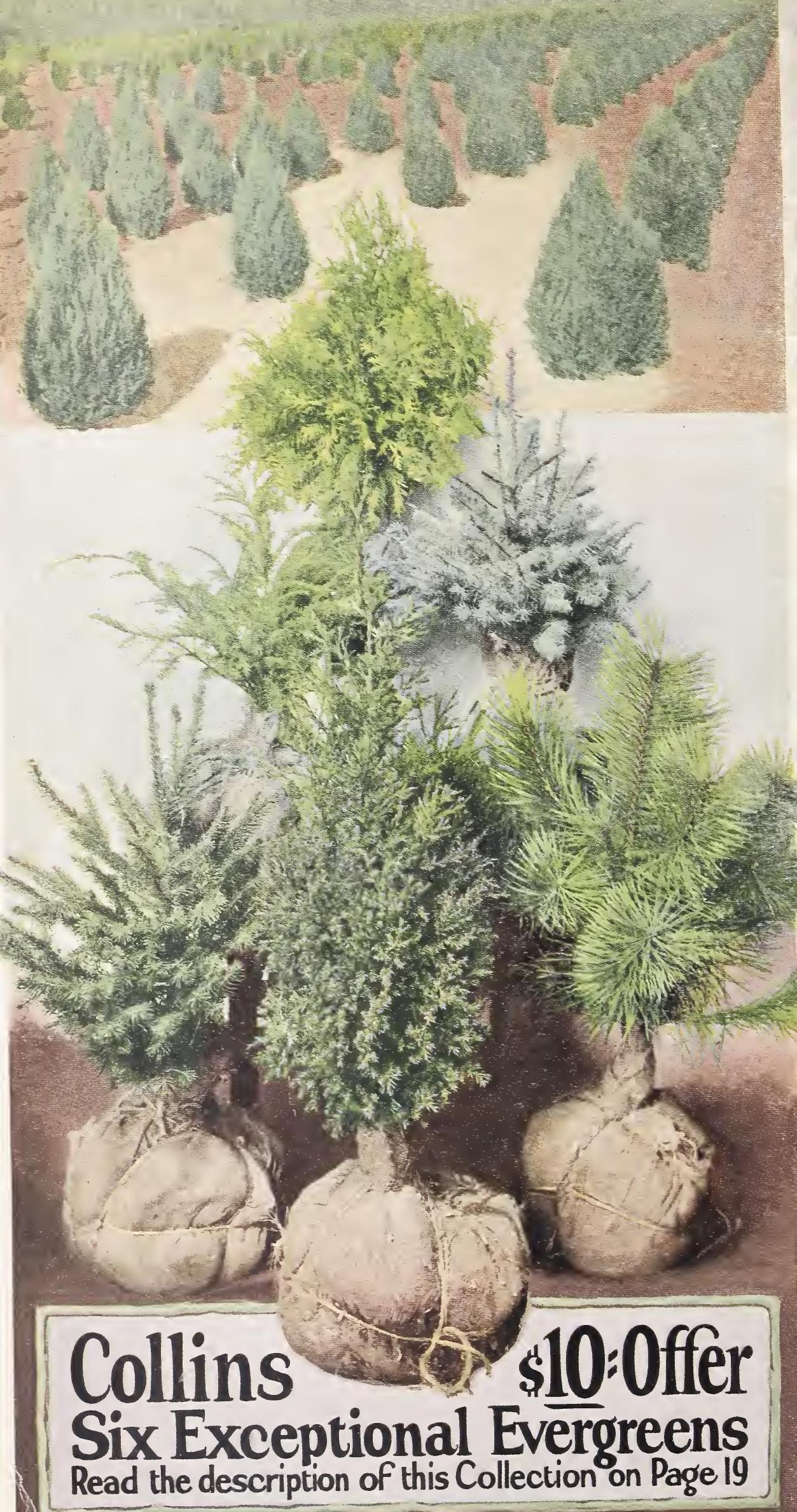

